\title{
The Physiology of Adaptation and Yield Expression in Olive
}

\section{D.J. Connor*}

Instituto de Agricultura Sostenible (CSIC) and Universidad de Córdoba

Apartado de Correos 4084

14080 Córdoba, Spain

and

The Institute of Land and Food Resources

The University of Melbourne

Victoria 3010, Australia

E. Fereres ${ }^{*}$

Instituto de Agricultura Sostenible (CSIC) and Universidad de Córdoba Apartado de Correos 4084

14080 Córdoba, Spain

\section{INTRODUCTION}

II. GROWTH AND DEVELOPMENT
A. Vegetative Growth
B. Floral Induction, Initiation, and Differentiation
C. Response of Flowering to Temperature
D. Flowering, Pollination, and Fertilization
E. Self Compatibility
F. Fruit Set, Filling, and Maturation
G. Efficiency of Reproductive Strategy

III. WATER RELATIONS
A. Collection of Water by Root Systems
B. Leaf Anatomy and Water Relations
C. The Olive Tree as a Hydraulic System
D. Control of Transpiration

IV. MINERAL NUTRITION
A. Deficiencies and Toxicities
B Extraction and Cycling of Nutrients in Orchards

V. CARBON ACCUMULATION
A. Leaf Photosynthesis
B. Interception of Radiation
C. Tree and Canopy Photosynthesis

VI. BIOMASS PARTITIONING AND REALIZATION OF YIELD
A. Movement of Assimilates from Leaves
B. Above- and Below-Ground Biomass
C. Shoots and Fruits
D. Assimilate Supply and Oil Formation

VII. STRESS PHYSIOLOGY
A. Drought
B. Low Temperature
C. Salinity
D. Waterlogging 
VIII. INTEGRATION OF RESPONSES

IX. RECOMMENDATIONS FOR FUTURE RESEARCH
A. Phenological Development
B. Carbon Assimilation and Partitioning
C. Water Relations
D. Nutrient Balance
X. CONCLUSION

*We thank Antonio Hall, Bob Loomis, María-Inés Mínguez, Hava Rapoport, David Smith and four reviewers for comments and suggestions on the manuscript and also Joan Girona, Miguel Pastor, Francisco Villalobos, and Francisco Orgaz for valued discussion. David Connor's study in Spain was funded by the Ministerio de Educación y Cultura, Spain.

\section{List of Abbreviations}

$\begin{array}{ll}\text { A } & \text { leaf photosynthetic rate } \\ \text { A }_{\text {max }} & \text { maximum rate of leaf photosynthesis } \\ \text { ATP } & \text { adenosine triphosphate } \\ \text { CAM } & \text { crassulacean acid metabolism } \\ \text { CC } & \text { canopy (vertical) cover } \\ \text { CoA } & \text { coenzyme A } \\ \text { CR } & \text { constructional respiration } \\ \text { EC } & \text { electrical conductivity } \\ \text { ET } & \text { evapotranspiration } \\ \text { ET } & \text { reference crop evapotranspiration } \\ \text { FAS } & \text { fatty acid synthase } \\ \text { FRF } & \text { fruit retention force } \\ \text { GR } & \text { glucose requirement for growth or maintenance } \\ \text { LAI } & \text { leaf area index } \\ \text { LSC } & \text { leaf specific hydraulic conductivity } \\ \text { MPK } & \text { monopotassium phosphate } \\ \text { MR } & \text { maintenance respiration } \\ \text { NADH } & \text { nicotinamide-adenine dinucleotide phosphate } \\ \text { NUE } & \text { nitrogen-use efficiency } \\ \text { PAR } & \text { photosynthetically active radiation } \\ \text { PRD } & \text { partial root zone drying } \\ \text { PS } & \text { phenological stage } \\ \text { Q } & \text { capacitance } \\ \text { RDI } & \text { reduced deficit irrigation } \\ \text { RLD } & \text { root length density } \\ \text { RUE } & \text { radiation-use efficiency } \\ \text { SLM } & \text { specific leaf mass } \\ \text { T } & \text { transpiration rate } \\ \text { TAG } & \text { triacylglycerol } \\ \text { TE } & \text { transpiration efficiency } \\ & \end{array}$


vapor pressure deficit

WUE

water-use efficiency 


\section{INTRODUCTION}

Olive (Olea europaea L., Oleaceae) has probably been in cultivation longer than any other tree species. It was domesticated around 3000 to $4000 \mathrm{BC}$ in the eastern Mediterranean and from there was spread widely in northern Africa, the Iberian Peninsula, and the rest of southern Europe by civilizations that successively occupied the region. Whereas olive is now renowned for high-quality food oil and for fruit for direct consumption, it was originally harvested for oil used as medicine, lamp fuel, and lubricant. During the last 500 years, olive has been taken to the Americas, South Africa, Australia, China, and Japan, but remains principally a crop of the Mediterraean Basin which accounted for $95 \%$ of world mean annual production of $2.5 \mathrm{Mt}$ oil during three years to 2002. Of the five major producers, Spain, with $42 \%$ of world production, was ahead of Italy, Greece, Turkey, and Tunisia (FAOSTAT 2003).

All cultivated olive belongs to a single species (O. europaea) along with the wild ancestors from which it was selected. As a result of the general use of vegetative propagation and the longevity of individual trees, many olive cultivars are probably within several generations of the wild types from which they were selected (Lavee 1990). Many trees are hundreds of years old and some may be thousands. Based on local knowledge, Miranovic (1994) reports 1000-year-old olive orchards of 'Zutica' on the Montenegrin Coast, with one tree over 2000 years. As a consequence, most traditional olive-growing regions depend on only a few of the more than 2000 recognized cultivars and clones. Similarly, small numbers of cultivars dominate production in each of the major, intensive areas of Spain, Greece, and Tunisia. In Spain, for example, of 262 recognized cultivars, just four, 'Picual', 'Cornicabra', 'Hojiblanca', and 'Lechin de Sevilla', occupy $68 \%$ of the olive area (Barranco and Rallo 2000). In Italy, however, there is no similar dominance of few cultivars. Rather there is much variation from locality to locality.

In the Mediterranean region, with its characteristic hot, low-rainfall summers, olive was developed as the crop of marginal land that was unsuitable for more intensive cultivation by reason of soil type, topography, or lack of water for irrigation. The traditional orchards are consequently of widely spaced trees, maintained with small canopy cover, and hence water demand, to ensure survival through the driest summers. The cultivation of olive is, however, changing. Large areas of widely spaced olives are being irrigated and the trees reshaped for mechanical harvesting. At the same time, most new orchards in the Mediterranean, and almost exclusively elsewhere, are being planted at high density, irrigated and fertilized for high yield, and shaped from the outset for mechanical harvesting. These changes are occurring rapidly and, in the absence of complete knowledge specific to olive, technology is being adapted from other crops, e.g. mechanical harvesting from wine grapes and reduced deficit irrigation (RDI) from stone and pome fruits (Mitchell and Chalmers 1982; Mitchell et al. 1989).

Despite its long history of cultivation, scientific understanding of olive is limited compared with that of other long-standing crops such as wheat and barley, or even new crops such as sunflower (Connor and Hall 1997). Traditional management of olive was established by trial and error without physiological understanding of responses to environment and management. A relatively recent treatise on olive (Rojo 1840), for example, commenced by acknowledging the major contribution to knowledge by 
Columela, one of the first agriculturalists from ancient Rome. Traditional techniques of olive production that have persisted for thousands of years may be optimal for local cultivars in local areas but they cannot be confidently extended to new locations or new forms of cultivation. One key to progress is to understand the physiological basis of those responses within a sound scientific framework.

The recent expansion of scientific research in olive justifies this new comprehensive review. New cultural techniques, with greater tree density, more water, improved nutrition, and mechanical harvesting, are both the cause and effect of new research that is expanding. This review will consider individual components of physiological response, leading to an integrated view of their interactions that determine growth, survival, resource-use efficiencies, and productivity under field conditions. It will supplement and update two previously published reviews (Bongi and Palliotti 1994; Lavee 1996), and the more restricted reviews of fruit set (Lavee 1986), salt tolerance (Gucci and Tattini 1997), water relations (Fernández and Moreno 1999), and flower induction and differentiation (Fabbri and Benelli 2000). It will evaluate the existing literature on olive within the established framework of plant and crop physiological science (see e.g. Taiz and Zeiger 1991; Loomis and Connor 1992) so that the consolidated knowledge can be applied to olive production, in whatever form, in all appropriate environments. A consequent important outcome will be the identification of areas where knowledge is inadequate and so the review will also contribute to setting priorities for future research.

\section{GROWTH AND DEVELOPMENT}

The size and activity of the foliage canopy determine the carbon gain and growth of olive trees. It is, however, the pattern of appearance of new organs that determines how that growth is progressively partitioned to buds, leaves and roots, and in consequence, how yield is determined annually and how trees change morphologically in the longer term.

Olive is widely reported as a day-neutral plant in which the rate of development through its biennial vegetative-reproductive cycle is governed climatologically by temperature and sunlight (assimilate supply). Since the only experimental evidence for this day neutrality resides in work with a single cultivar, 'Rubra' (Hackett and Hartmann 1964), this response of olive does merit wider investigation. The biennial cycle (Rallo 1998), one in which individual trees bear in alternate years, arises because olive flowers on 1-year-old shoots and the induction of buds during summer is affected by the presence, at that time, of the current year's fruit. The interaction between external environment and the internal physiological responses that operate over the extended period from induction in summer to flowering in spring is, however, poorly understood. Sanz-Cortés et al. (2002) developed a numerical scale for the vegetative and floral phenological stages (PS) that is consistent with scales used widely in other tree crops. This standardized scale should facilitate description of developmental patterns and research directed to understand controls of phenological development in olive.

\section{A. Vegetative Growth}

The production of nodes, the expansion of leaves, and the thickening of stems can occur at any time during the year depending upon temperature, water supply, and solar 
radiation. Vegetative growth is, however, commonly constrained by low temperature in winter, and in rain-fed systems, by water supply during summer. While, irrigated orchards may maintain shoot growth and leaf expansion from spring through autumn, rain-fed orchards typically display two flushes of vegetative growth, in spring and autumn, respectively.

Moriana et al. (2003) made detailed records of trunk growth over an annual cycle and showed that fruit load effected trunk growth patterns of mature trees. Growth in an irrigated tree, following harvest of a heavy fruit load (and thus very small load in the current year), was very slow in spring and increased more or less linearly, exhibiting maximum growth rates at the end of summer and in early autumn. In contrast, a tree with a heavy crop grew faster during spring but slowed markedly in summer and autumn. Trunks of mature trees under severe water deficits did not grow at all and even shrunk during the driest periods.

Little is known of the dynamics of root growth of olive trees in the field. Although olive root systems can be extensive and deep, measurements of root length density (RLD, $\mathrm{cm} \mathrm{cm}^{-3}$ ) suggest that values usually range between 0.1 and $1.0 \mathrm{~cm} \mathrm{~cm}^{-3}$ (E. Fereres, unpublished), less than in herbaceous crops and some deciduous orchards (Fereres and Goldhamer 1990). The seasonal distribution of root growth has been studied by Fernández et al. (1991) for 'Manzanillo' (southern Spain) and Palese et al. (2000) for 'Coratina' (southern Italy). Both studies used mini-rhizotrons to compare rain-fed with irrigated orchards planted at $6 \times 6 \mathrm{~m}$. Irrigation in the Spanish study was by drip and in Italy by a single micro-jet per tree spanning $1 \mathrm{~m}^{2}$. Observations from mini-rhizotrons are considered to overestimate actual RLD but they can provide reliable estimates of comparative activity and, given that caution, the overall conclusions of the two studies are similar. Under localized irrigation, RLD increased in the wetted zones and while roots in rain-fed orchards extended widely, those in drip- and micro-spray-irrigated orchards tended to be concentrated within the wetted volume. Maximum RLD occurred in winter-spring in rain-fed systems but in summer in irrigated systems. The studies have thus provided evidence of the plasticity of olive root systems to adjust to the localized wetting patterns, now common in many new plantings under micro-irrigation. The evergreen nature of the olive, and the usual wetting of the whole profile in winter in Mediterranean climates, usually ensures that roots proliferate within the potential root zone, regardless of the irrigation method.

Root morphology is also affected by water supply. Lo Gullo et al. (1998) observed that that roots responded to drought stress by forming a multi-layered and more suberized endodermis, while Fernández et al. (1994) reported that the transition to secondary growth occurs closer to the apex for roots that extend into dry rather than wet soil.

\section{B. Floral Induction, Initiation, and Differentiation}

Flowering in olive occurs on buds formed in the leaf axils on shoots produced in the previous year. The sequence of development passes through induction, when changes in gene expression commit the future development of buds to floral structures, to initiation, when the floral structures are evident by microscopic examination, and finally to differentiation as the buds grow to form mature flowers. 
Floral induction occurs in mid-summer ( 7 to 8 weeks after full bloom) around the time of pit hardening (endocarp sclerification) of the current season's fruit, i.e. stage PS75 (Sanz-Cortés et al. 2002). Floral induction is apparently influenced by compounds released by the developing fruit and seed that are translocated to the buds (Stutte and Martin 1986; Rallo and Martin 1991; Fernández-Escobar et al. 1992; Lavee 1996; Fabbri and Benelli 2000). Induction cannot be observed visually but associated changes have been detected by histochemical techniques. Thus, Pinney and Polito (1990) and Navarro et al. (1990), both working with 'Manzanillo', recorded changes in the ribulose nucleic acid content of buds in autumn that are linked to morphological changes that precede floral initiation.

The recognition of induction as a separate phase that is established before winter is important to understanding the complexities of flowering in olive. Vernalization (exposure to cool temperatures, $<7^{\circ} \mathrm{C}$ ) controls the second phase of the reproductive process, i.e. the initiation of induced buds, sometimes described as their "release from dormancy" ( Rallo and Martin 1991; Fabbri and Benelli 2000). After bud burst in Spring the entire tree enters a period of growth with a dominant response to increasing temperature. This changed response to temperature explains why early analyses of thermal response of flowering in olive emphasized the importance of alternating temperatures and the conflicting requirements between low temperatures required for vernalization and warm temperatures required for growth and subsequent flowering (Denney and McEachern 1983).

Although some morphological signs may be evident earlier, floral initiation can be unequivocally recognized soon after bud burst (PS53) about two months prior to flowering (PS60) in late Spring (Rapoport 1998; de la Rosa et al. 2000). Some buds are initiated and some of those differentiate to produce inflorescences. It is unknown if this results from incomplete induction or if the process is reversible. In addition to internal controls, environmental conditions following bud burst are important determinants of floral morphology, including number of flowers per inflorescence and the proportion of staminate flowers (Rallo et al. 1981; Rapoport and Rallo 1991b).

The inhibition of floral induction by fruit and seed growth also contributes to alternate bearing that is characteristic of olive. Years of intense fruiting ("on") tend to be followed by years of restricted flowering ("off" years). This pattern of biennial flowering and yield, common in fruit trees, is well expressed in olive (Rallo 1998).

\section{Response of Flowering to Temperature}

Hartmann's group in California ( Hartmann 1953; Hartmann and Porlingis 1958; Hackett and Hartmann 1967; Hartmann and Whisler 1975) studied the role of temperature, including chilling in the flowering response of olive. Based on this work, Denney and McEachern (1983) proposed an optimum temperature regime for flowering of 2 to $4^{\circ} \mathrm{C}$ (minima) and 15.5 to $19^{\circ} \mathrm{C}$ (maximum). Plants grown at a constant temperature of $7^{\circ} \mathrm{C}$ produced few if any flowers so this fluctuating temperature regime was interpreted as providing the optimum balance between the chilling signal (vernalization) that released induced buds for further development and the warm conditions that supported the associated growth, without high temperature that could reverse the chilling effect (devernalization). It is unknown how widely this model can be applied, or if optimum 
temperatures or durations vary among cultivars. It is known, however, that a chilling requirement is not absolute because olives flower and produce fruit in various subtropical locations where vernalization requirements, as defined above, are not met.

A temperature-based model for predicting flowering in olive is urgently needed to specify individual responses of vernalization and devernalization during the successive stages from induction through initiation and differentiation to full bloom. Hopefully this advance would make it possible to evaluate the actual adaptive range of cultivars and untangle the internal non-temperature effects on flowering. Ayerza and Sibbett (2001) evaluated the suitability of new sites for olive production in the Chaco Region of Argentina by comparing the probabilities of minimum and maximum temperatures in the ranges 0.0 to 12.5 and 12.5 to $21.1^{\circ} \mathrm{C}$, respectively, and the probabilities of extreme cold $\left(<0^{\circ} \mathrm{C}\right)$ and heat $\left(>37.8^{\circ} \mathrm{C}\right)$ during flowering periods, with those of established sites in Argentina, Italy, Mexico, Spain, and USA. By these criteria, all Italian and Spanish sites had at least 150 vernalizing days per year while no existing Argentine site, San Juan ( $31^{\circ}$ $34^{\prime}$ S, 598 m), Mendoza ( $32^{0} 50^{\prime}$ S, 704 m), or San Rafael (34 $35^{\circ}, 748$ m), exceeded 110. All proposed new Chaco sites had less than 60 vernalising days and also recorded the greatest daily probabilities of heat damage during flowering. On this basis caution is warranted in expanding olive areas in Argentina and comparable environments and should be based on evaluations of the potential damage of high temperature at flowering rather than on low probability of vernalization. This is evident because olives flower and bear fruit in a number of subtropical regions in the world. The same study (Ayerza and Sibbett 2001) reported that 'Criollo' can bear good crops at a coastal site at Ica, Peru (14 $05^{\prime} \mathrm{S}, 398 \mathrm{~m}$ ) without, according to the above definition, any exposure to vernalising temperatures.

The flowering of 'Criollo', without evident vernalization, on the coastal lowlands of Peru, is not only a matter of cultivar difference because other cultivars are grown there and they also flower. It is common practice in that region to suspend irrigation during the dry winter months. This is not simply a copy of traditional management practices in Spain where winters are cool and rainy; rather the practice has developed because water stress promotes flowering once irrigation is resumed in spring (F. Castillo, pers. comm.). It seems that water stress at that time plays a role in the flowering of olive similar to that of low winter temperatures in the Mediterranean. This proposed similarity may offer an important physiological lead to be pursued in untangling the nature of internal controls of flowering in olive.

The beginnings of a multistage model of flowering response can be found in Alcalá and Barranco (1992). Working with flowering dates recorded for a collection of 170 cultivars at Córdoba, Spain, they established the period during which heat accumulation above a threshold temperature best explained the variation in flowering times over a ten-year period. They established that a common mean daily threshold temperature of $12.5^{\circ} \mathrm{C}$ was appropriate for all cultivars but that the best fit to commencement of the heat accumulation period varied among cultivars from 1 January to 1 March. 


\section{Flowering, Pollination, and Fertilization}

Flowers are produced in great numbers in paniculate inflorescences of up to 40 flowers each, depending on cultivar and growing conditions. One report (Tous and Ferguson 1997), reports up to 500,000 flowers per tree under Calfornian conditions but the number clearly depends upon tree size and growing conditions. The individual branches of inflorescences contain from 1 to 4 flowers on short peduncles (Martin 1990; Rapoport 1998). Flowers can be bisexual (perfect) or male (staminate), the proportions depending upon cultivar, growing conditions, "on" or "off" condition, and position on tree. In individual studies, the percentage of perfect flowers has ranged from 20 to 96 (Rapoport and Rallo 1991b; Cuevas et al. 1994; Dimassi et al. 1999; Ferrara et al. 1999; Ghrisi et al. 1999). Dimassi et al. (1999) recorded a greater proportion of perfect flowers in the middle of inflorescences located in the middle of flowering shoots on the southern (sunny) side of trees, the most favorable location for the growth of individual shoots on trees in the northern hemisphere. Perfect flowers contain four ovules, two in each of two locules (Rapoport 1998) and are short lived. Pollen is produced in abundance over ca. 5 days and individual stigmas remain receptive for ca. 2 days. Flowering in individual trees lasts for ca. 10 days and in orchards for ca. 20 to 30 days.

Pollination is by wind and is hindered by strong winds and rain and may also suffer from high temperature or hot winds that desiccate pollen and stigmas. For individual trees, the success of such a haphazard process increases with flower number and pollen production. Subsequent fertilization comprises a number of steps. It involves recognition of pollen by the stigma, and in response, the growth of pollen tubes each carrying two gametes downwards within the style towards the ovules in the embryo sac. Usually a single pollen tube enters the embryo sac (Rapoport 1998). This process must be complete while the ovule remains receptive and hence pollen vigor is important, especially when plant and environmental conditions are suboptimal for ovule fertility and pollination. Staminate flowers desiccate first, quickly followed by perfect flowers after successful fertilization (Rapoport and Rallo 1991b).

It has been observed that pollen-tubes grow more vigorously following cross pollination between cultivars (Fernández-Escobar et al. 1983; Ghrisi et al. 1999; Cuevas et al. 2001).

\section{E. Self Compatibility}

Olive is partially self-incompatible so cross pollination increases fruit set and yield. There is good evidence that cross pollination leads to more vigorous growth of pollen tubes (Ghrisi et al. 1999; Cuevas et al. 2001) that can be advantageous in adverse environmental conditions when pollen is in short supply or stigma receptivity or ovule fertility is low (Fernández-Escobar et al. 1983). Under those conditions, high pollen-tube vigor may improve fruit set and yield. Recent work with crosses among 'Picual', 'Hojiblanca', 'Manzanilla', and 'Arbequina' revealed that improved fertilization was not, however, the only advantage of cross-pollination (Cuevas et al. 2001). Those experiments report increases in both the proportion of fruit retained and the number of fruit set. This identifies the existence of additional recognition-acceptance-rejection mechanisms operating between embryo and maternal tissue that are clearly important 
given the considerable experience that greater fruit set need not translate to greater fruit retention.

The benefit of cross-pollination is well recognised in many production zones in the form of specific recommendations for pollinizer-receptor pairs and maximum distances (e.g. $30 \mathrm{~m}$ ) between pollinizer trees in orchard design (Griggs et al. 1975; Rallo 1998; Dimassi et al. 1999; Ferrara et al. 1999). In other regions, where little attention has been previously paid to cross pollination, benefits are now being detected. An example is found in Jaen Province, Andalusia, Spain, where 200,000 ha have been planted to 'Picual' without concern to the provision of pollinizers. Recent work in that region has detected advantages to fruit set and yield by cross pollination among the cultivars 'Picual', 'Hojiblanca', and 'Arbequina'. This has led to recommendations for associative plantings of those cultivars, considered to be especially valuable in years of poor flowering (Cuevas et al. 2001). There is ample evidence, however, that some major cultivars have a relatively high self-compatibility that provides adequate pollination under most seasonal conditions. Examples include the extensive plantings of 'Picual' in Andalusia; 'Chemlali' in central Tunisia, and 'Arbequina' in Catalonia , each grown widely without pollinizers (Anon. 2000). The causes and consequences of this behavior need to be investigated. Note that detection of the degree of self-compatibility is potentially underestimated by the routine method of bagging inflorescences on individual trees. Quite apart from the danger of unsuitable environmental conditions within the bags, this technique evaluates within-tree and not within-cultivar compatibility.

The inclusion of pollinizers is easily satisfied in commercial practice because there are good reasons to design orchards with more than one cultivar, including, diversification of oil quality, spreading harvest requirements, minimizing risk from environmental variability, and changing market preferences. Further work is urgently needed, however, because uncertainties remain on the necessity of receptor-pollinizer pairs, and their optimum combinations, especially in new olive-producing regions.

\section{F. Fruit Set, Filling, and Maturation}

In most cultivars, a single fertilized ovary develops per inflorescence but there are exceptions, particularly in cultivars with small fruits such as 'Arbequina' and 'Koroneiki' that usually produce more on most inflorescences. Most ovaries, fertilized or not, soon abort. Fruit set at 2 to 3 weeks after flowering (PS71) may account for 10 to $15 \%$ of total flowers but it continues to decrease, to 7 to $10 \%$, in the following 4 to 5 weeks (i.e. 6 to 7 weeks after full bloom, PS75). Thus in 'Manzanillo de Sevilla', just 25\% of ovaries were retained at the end of flowering (marked by petal drop, PS68) (Troncoso et al. 1978), and only 5\% survived to fruit filling (Rapoport and Rallo 1991a). Analysis of growth patterns of ovaries following fertilization indicates a possible role of substrate competition (Rallo and Suarez 1989; Rapoport and Rallo 1991a). Some ovaries develop parthenocarpically, i.e. without fertilization. Those fruits (zofairones) are smaller and commercially unimportant because most abort quickly and few persist until harvest (Rapoport 1998). Their formation may, however, be indicative of environmental conditions or physiological defects during flower formation, pollination, or fertilization. The characteristic of many olive cultivars to set a single fruit per inflorescence establishes the inflorescence as the effective reproductive unit (Rallo and Fernández-Escobar 1985) 
which is more appropriately, as well as more easily, used than flower number to calculate an index of fruit set.

Despite the usual large losses of flowers and fruits, partial fruit removal (fruit thinning) is often used to increase fruit size. This can be achieved by mechanical (beating with sticks) and chemical methods (e.g. naphthaleneacetic acid) during early stages of fruit growth (PS71) (Kreuger et al. 2002). For table cultivars, where fruit size determines quality, as many as $70 \%$ of fruitlets may be removed in years of heavy fruit set. Fruit thinning is also undertaken in attempts to minimize alternate bearing but it may be an ineffective practice because it appears that complete flower removal is required to ensure return to bloom (Rallo et al. 1994).

Growth of the olive fruit (botanically a drupe) lasts for 4 to 5 months (PS71 to PS89) and involves cell division, cell expansion, and storage of metabolites, dominantly, but not exclusively, in that order. After a 1 to 2 months of intense cellular division, during which $80 \%$ of final cell number is formed (Manrique et al. 1999), the three component tissues, exocarp, mesocarp, and endocarp, can be identified visually. The first, comprising a layer of epidermal cells rich in chloroplasts, is covered by a thin cuticle and contains rudimentary stomata that are lost in the following month (Proietti et al. 1999a). The mesocarp tissue is rich in protoplasm and surrounds the endocarp that is increasingly sclerified. Then, about 2 to 3 months after fruit set and about half way through the fruit-growth period, the fruit is covered by a waxy layer, mesocarp cells have developed vacuoles, and the endocarp has completely sclerified (pit hardening, PS75) and ceases enlargement. Then follows the major period of oil deposition that continues until maturity. This sequential pattern of tissue growth determines the response of the major fruit characteristics such as size, weight, pulp/pit ratio, and oil content to weather, fruit load, and orchard management practices (see also Section VID).

An issue of considerable commercial importance is the intrinsic seasonal pattern of fruit growth. Initial reports indicated that the pattern of olive fruit growth (Lavee 1986, 1996) followed a double sigmoid, that is characteristic of deciduous stone fruits (Mitchell and Chalmers 1982). However, while periods of suspended fruit growth commonly coincide with pit hardening in rain-fed olive orchards subject to summer water shortage, fruit growth continues under irrigation. Fruit dry weight increases linearly during the first part of fruit growth (Fig. 1) in the absence of water deficits, slowing when oil accumulation processes (Section VID) increase the energy content of dry matter (Tombesi 1994).

At fruit maturity, three abscission zones develop, one where the peduncle joins the branch, and two more where the pedicel joins the peduncle and fruit, respectively (Barranco et al. 2002). In consequence, the physical force required to remove fruit decreases during maturation. The process of abscission is under the control of ethylene released by the maturing fruit, and there is considerable variation between cultivars (Hartmann et al. 1970; Rallo 1998). Controlled and synchronized fruit fall benefits fruit quality, especially with the advent of mechanical harvesting when the objective is to remove all fruit in a single operation without physical damage to the tree. Various treatments are available to decrease retention force, including the application by spray of ethylene compounds and monopotassium phosphate (MKP). The latter appears to stimulate release of ethylene compounds (Yamada and Martin 1994). Fruit retention 
force (FRF) of 'Arbequina' and 'Picual' decreased within 2 weeks of application of 3\% MKP (with surfactants) and remained less than the naturally declining FRF (control) for up to 10 weeks (Barranco et al. 2002). Harvest efficiency, the proportion of fruits harvested, increased from 45 to $60 \%$, with best results obtained 4 weeks after treatment. Treatment did not change the distribution of separation zones; most fruit were released at the peduncle and least at the fruit itself.

\section{G. Efficiency of Reproductive Strategy}

In years of heavy flowering, a fruit set of 1 to $2 \%$ of flowers can be adequate for a good commercial yield and as many as $50 \%$ of flowers can be removed without effecting final fruit number (Lavee et al. 1999). The energetic and nutrient efficiencies of the massive flowering and fruit loss of olive appear small but there is little quantitative information on these aspects. Bouranis et al. (1999) presented biomass and nutrient content of olive inflorescences at flowering. Assuming 2 million inflorescences ha ${ }^{-1}$ (200 trees ha ${ }^{-1}$ with an average of 10,000 inflorescences of $70 \mathrm{mg}$ dry weight each), the total dry weight at full flowering would amount to $140 \mathrm{~kg} \mathrm{ha}^{-1}$, containing around $300 \mathrm{~g} \mathrm{~N}, 150 \mathrm{~g} \mathrm{P}, 850 \mathrm{~g}$ $\mathrm{K}, 500 \mathrm{~g} \mathrm{Ca}, 40 \mathrm{~g} \mathrm{Mg}, 18 \mathrm{~g} \mathrm{Fe}$, and around $2 \mathrm{~g}$ each of $\mathrm{Cu}, \mathrm{Zn}$, and $\mathrm{Mn}$ (Table 2). This biomass could be easily produced by normal olive canopies with growth rates that would approach $65 \mathrm{~kg} \mathrm{ha}^{-1}$ day $^{-1}$ in the month up to flowering, without the necessity to draw on reserves. That growth rate was calculated using a daily incoming photosynthetically active radiation (PAR) of $8 \mathrm{MJ} \mathrm{m}^{-2}$ with $60 \%$ intercepted by the canopy and a radiationuse efficiency (RUE) of $1.35 \mathrm{~g} \mathrm{MJ}^{-1}$ intercepted PAR measured by Mariscal et al. (2000b) on young plantations of 'Picual' growing at high density. The nutrient requirements of this growth are not substantial and there is also the possibility of substantial mobilization of nutrients into surviving fruitlets during the flower- and fruit-abscission period.

Overall, we identify three features that minimize energy and nutrient costs of reproductive strategy in the olive. First, the large proportion of male flowers increases pollen production at lower cost per flower or pollen grain than for perfect flowers. Second, the rapid abortion of flowers following successful fertilization on individual inflorescences further reduces wasteful tissue growth. Third, the rapid abortion of many fertilized ovaries occurs before they become significant sinks for assimilate. On balance olive may have an effective strategy when compared to the alternative of producing nectar, adopted to secure pollination in many species.

\section{WATER ECONOMY}

The metabolism of all terrestrial plants operates in an aqueous phase, placing them in the hostile interface between a transiently wet soil and a relatively dry atmosphere. In this sense, plant growth can be considered as resulting from an interchange of internal water for carbon dioxide from the atmosphere required for photosynthesis. The loss of water from plant leaves (transpiration, T) establishes internal flows that eventually draw replacement water from the soil via roots. Rates of water flow into and within the tree depend upon gradients of water potential $(\partial \psi / \partial z)$ and hydraulic conductance to transport, with the xylem providing a high-conductance, direct, internal pathway between roots and canopy. The internal water status of plants thus varies dynamically in response to the balance between loss and uptake. The important short-term dynamic is diurnal. 
Evaporative demand increases as the day advances and plant water content falls to a minimum around midday provided soil water content is high. It recovers in the evening so that plants may then approach equilibrium with the water potential of the soil $\left(\psi_{\mathrm{s}}\right)$. As the root zone dries, however, leaf water potential $\left(\psi_{1}\right)$ falls further each day and, despite gradual control of water loss by stomatal closure, recovery slows until the soil is rewetted by rainfall or irrigation. After a prolonged dry period $\psi_{1}$ is much lower than $\psi_{\mathrm{s}}$, even by dawn the following day. If serious internal water deficit persists, metabolism is disrupted and plants eventually die from desiccation.

Growth and survival, therefore, require adaptations to the uptake and conservation of internal water status that are appropriate to the environmental patterns of water supply and demand. The special features by which the evergreen olive is able to maintain an adequate internal water status during severe summer drought derive from its ability to restrict loss of water to the atmosphere and withstand the substantial internal water deficit that is required to maximize extraction of water from the soil. In practice, orchard management greatly assists this balance between uptake and loss by adjusting the size of the transpiring canopy that intercepts radiation by controlling the ground cover that minimizes or prevents non-tree transpiration, and in some situations by full or deficit irrigation. Canopy volume and cover are managed through planting density and pruning (Pastor Munoz Cobo and Humanes Guillen 1996; Gucci and Cantini 2000), while ground cover is controlled either by tillage or herbicides (Pastor et al. 1998).

\section{A. Collection of Water by Root Systems}

Root systems are possibly the least explored area in crop physiology even though their roles in the uptake of water and nutrients are central to crop adaptation and management. Whereas we have relatively good information on the production, distribution, activity, and lifespan of leaves, comparable information is not available for roots. Without information on the seasonal and spatial distribution of length, surface area, and activity we cannot expect to properly understand the capacity of root systems to absorb water and nutrients. Newly formed roots probably provide the uptake capacity while older roots, that survive harsh conditions and predation to undergo secondary thickening, provide the framework for exploration, the conduit for transport to foliage via trunk, and anchorage to the soil. There are, however, few data to help us quantify the processes and understand their dynamics in olive.

Most olive trees are produced vegetatively and do not have root systems dominated, at the outset, by a principal axis as occurs in trees grown from seedlings. Rather, many adventitious roots are produced from the base of either woody or semiwoody cuttings. The lateral spread of these root branches and the depth they achieve depend upon tree vigor, soil depth, mechanical resistance, aeration, moisture content, fertility, pruning, and perhaps cultivar (Navarro and Parra 1998). There is folklore that olive tree roots extend laterally only to the width of the canopy and this may be true of surface roots in orchards that are frequently tilled. It can be more reasonably concluded, however, that the successful tree spacing of traditional orchards are those that explore the soil volume completely, at least in the driest times. The success of olive cultivation in marginal soils must be attributed, at least in part, to its root system, not only in extent but also in its plasticity and capacity to react quickly to changes in soil water content. Unfortunately, we can only infer some of these properties indirectly, from shoot behavior. 
A number of papers refer to aspects of root distribution and performance in olive ( Rieger 1995; Moreno et al. 1996; Palese et al. 2000) but there is little systematic information about root distributions and dynamics. In one study, Fernandez et al. (1991) made extensive observations by trench excavation and auger sampling to $2 \mathrm{~m}$ depth within $7 \times 7$ m orchards of 20 year-old 'Manzanillo' (table olive) growing on a deep sandy loam soil at Sevilla, Spain. The observations, made in summer, revealed that irrigation increased root length density (RLD) but decreased the spread of roots, largely confining them to the wetted area. It is probable that roots, developed outside the wetted area during the rainy periods in that treatment, either died or were not detected by the sampling technique. In a 12-year-old rain-fed treatment, roots were well distributed to 2 $\mathrm{m}$ depth and to a distance of $2 \mathrm{~m}$ from the tree but nowhere with densities exceeding 0.5 $\mathrm{cm} \mathrm{cm}^{-3}$. Except under the canopy, roots were less frequent in the surface than in lower layers. In contrast, drip irrigation to $0.4 \mathrm{E}_{\mathrm{pan}}$ for $8 \mathrm{y}$ had dramatic effects, with roots largely confined to the dripper line and RLD up to $6 \mathrm{~cm} \mathrm{~cm}^{-3}$ in the surface layer adjacent to the trees. Such values are extremely high and suggest either extreme confinement or contamination of samples by roots of weeds. In another plot of finer surface soil texture, but where root penetration was restricted to $80 \mathrm{~cm}$ depth by an impervious layer, RLD in similar locations never exceeded $1 \mathrm{~cm} \mathrm{~cm}^{-3}$ and roots were more evenly distributed in the wetted volume. Away from the canopy, there were few roots in the surface along the dripper line, or at depth on transects running at right angles to it. Tillage, undertaken routinely three times per year to $20 \mathrm{~cm}$, could explain the low surface densities in both treatments, but there is no explanation for absence of roots at depth under irrigation.

Analysis of the two treatments of Fernández et al. (1991) can be extended to estimate total root length as an important parameter of the water-collecting capacity of root systems. Here, RLD profiles to $1.5 \mathrm{~m}$ and spatial distributions within $4 \times 4 \mathrm{~m}$ centred on the tree reveal mean RLD for roots $<0.5 \mathrm{~mm}$ diameter of 0.177 and $0.224 \mathrm{~cm}$ $\mathrm{cm}^{-3}$ for rain-fed and irrigated treatments, respectively. If this soil volume $\left(24 \mathrm{~m}^{3}\right)$ sampled most of the root system, then the corresponding root lengths were 42.4 and 53.6 $\mathrm{km}$ per tree. Even allowing for the smaller tree density and estimation of RLD from root weight that possibly underestimates the total length of fine roots, these estimates greatly exceed those reported for 6-year-old 'Coratina' at $6 \times 3 \mathrm{~m}$ spacing (Dichio et al. 2002). There, RLD in irrigated and rain-fed trees of 0.022 and $0.018 \mathrm{~cm} \mathrm{~cm}^{-3}$ within explored volumes of 16.8 and $13.4 \mathrm{~m}^{3}$, estimate total length per tree at 3.7 and $2.5 \mathrm{~km}$, respectively.

In terms of tree water balance, the importance of root length resides in the capacity of the root system to obtain water to support the transpiring leaf area (see Section IIID). In sunflower, Connor and Jones (1985) recorded root lengths of 7.8 and $5.2 \mathrm{~km} \mathrm{~m}^{-2}$ ground area, corresponding to root length/leaf area ratios of 2.5 and $4.8 \mathrm{~km}$ $\mathrm{m}^{-2}$ leaf area, for rain-fed and irrigated crops, respectively. If the LAI of the rain-fed olive orchard (Fernández et al. 1991) was 0.4, a small but typical value of a good orchard subjected to the severe pruning practices in that area, then at $7 \times 7 \mathrm{~m} \mathrm{spacing}$, the root length/leaf area ratio would vary from 2.2 to $2.7 \mathrm{~km} \mathrm{~m}^{-2}$, a comparable value to that of sunflower. The contrast between RLD reported in the two studies, in Spain and Italy respectively, is an illustration of the uncertainties, assumptions, and differences found in the literature on this subject. 
In many species, colonization of roots by mychorrizae is known to affect root morphology and assist the uptake of water and nutrients, especially under conditions of low fertility and water supply. Arbuscular mycorrhizae have been recorded in olive (Hayman et al. 1976) and while there is no information on the impact on tree performance in the field, growth advantages have been reported in rooted cuttings. Citernesi et al. (1998) recorded more extensive and more branched root systems in 'Frantoio', 'Moraiolo', and 'Leccino' and greater shoot growth in 'Frantoio' and 'Moraiolo' following inoculation by Glomus mosseae.

\section{B. Leaf Anatomy and Water Relations}

Olive leaves are well adapted to conditions of water shortage. They are small $(5-6 \mathrm{~cm}$ long and $1-1.5 \mathrm{~cm}$ at widest point), sclerophyllous, and have stomata on the lower (abaxial) surface only. The specific leaf mass (SLM) was in the range 190 to $220 \mathrm{~g} \mathrm{~m}^{-2}$ for field-grown plants of 'Picual' (Mariscal et al. 2000b), although smaller values are reported for plants grown under controlled conditions (e.g. $130 \mathrm{~g} \mathrm{~m}^{-2}$ for 'Frantoio' and 'Leccino') (Gucci et al. 1997). Leaf surfaces, especially the abaxial ones, are covered with wax sheets and peltate trichomes. The latter are characteristic scales supported above the epidermis on single cells (Fahn 1986). Olive invests a considerable amount of biomass in trichomes, estimated at $2.6 \%$ of leaf dry matter for 'Koroneiki' (Karabourniotis et al. 1992). These trichomes confer a less green color to the abaxial surface of leaves, that is especially noticeable in some cultivars, e.g. the appropriately named 'Hojiblanca. Mariscal et al. (2000a) measured the reflectivities of adaxial and abaxial surfaces of three cultivars. 'Hojiblanca' $(0.063,0.13)$, was the most reflective, followed by 'Picual' $(0.06,0.12)$, and then 'Arbequina' $(0.06,0.10)$. High reflectivity, combined with small leaf size, assists with dissipation of sensible heat thus minimizing differences between leaf and air temperatures, a feature particularly important when stomata close under conditions of water shortage.

The internal structure of the leaf is comprised of two layers of elongated palisade cells, one associated with each epidermis, that enclose the mesophyll with characteristically thick cell walls (Bongi et al. 1987a), dispersed vascular bundles, and lignified strengthening tissues. The upper and lower palisade layers are usually three and one cell deep, respectively (Chartzoulakis et al. 1999; Bosabalidis and Kofidis 2002). The compactness of the internal structures explains the large SLM, the low transmissivity to PAR $(<0.0002)$ (Mariscal et al. 2000a), and the small area of mesophyll cells exposed to air within the leaf, estimated in the range 6 to $15 \mathrm{~m}^{2} \mathrm{~m}^{-2}$ leaf area for 'Ascolana' and 'Koroneiki', respectively (Bongi et al. 1987b; Chartzoulakis et al. 1999). The consequence is a small internal conductance to water vapor transport of around $0.4 \mathrm{mmol}$ $\mathrm{m}^{-2} \mathrm{~s}^{-1}$ (Chartzoulakis et al. 1999) for 'Mastoidis' and 'Koroneiki'. Stomata are small (length by breadth $=$ ca. 25 by $20 \mu \mathrm{m}$ ) with apertures ca. 11 by $5 \mu \mathrm{m}$ and are embedded in the abaxial epidermis at densities of 400 to $800 \mathrm{~mm}^{-2}$ for 'Mastoidis' and 'Koroneiki' (Bosabalidis and Kofidis 2002). The stomatal characteristics, combined with the waxy cuticle and trichomes afford good control over water loss by transpiration. The conductance of the waxy cuticle is negligible so that leaf conductance to water vapor transfer from sub-stomatal cavities to the boundary layer $\left(\mathrm{g}_{\mathrm{l}}\right)$ is essentially equal to the stomatal conductance $\left(g_{s}\right)$. Many papers cited in this review use $g_{s}$ synonymously with $g_{1}$. 
Leaf size and structure vary among cultivars. Chartzoulakis et al. (1999) and Bosabalidis and Kofidis (2002) provide comparisons of leaf anatomy of the two major cultivars, 'Mastoidis' and 'Koroneiki', grown on the island of Crete including their responses to water shortage. Under water stress, leaves were smaller and thinner and were composed of more, smaller, and more densely packed cells in each tissue type. Trichomes and stomata were more numerous. The net result was higher reflectivity, lessconductive cuticles, improved stomatal control, and a smaller cell area exposed for evaporation within the mesophyll tissue, i.e. smaller $\mathrm{g}_{\mathrm{w}}$ (Bongi et al. 1987b). Bosabalidis and Kofidis (2002) also established differences in cultivar response to water shortage. While there were no differences between the cultivars in cell wall elasticity or osmotic adjustment, greater response in stomata and trichome densities in 'Koroneiki' were consistent with its perceived greater drought tolerance.

Cell turgor develops due to inflow of water in response to low osmotic potential $\left(\psi_{\pi}\right)$. When water loss is excessive, cells lose turgor to the detriment of cell expansion in growing tissues, structural stability, metabolism, and guard cell movement for stomatal control. Loss of water lowers $\psi_{\pi}$ and therefore increases ability to absorb water from neighboring cells and tissues, and in the case of roots, to withdraw water from the soil. Many plants, however, have developed the ability to further decrease $\psi_{\pi}$ during water shortage and maintain turgor, metabolism, and water uptake, by the accumulation of osmotically active ions and metabolites. This is known as osmotic adjustment and in olive, the accumulation of mannitol (Flora and Matore 1993; Dichio et al. 2003) plays a major role.

\section{The Olive Tree as a Hydraulic System}

A tree can be represented hydraulically as a conductor-capacitor model in which the canopy is connected in series to the root system by the xylem, and each of the three components is in turn connected in parallel to internal storage tissues (Fig. 2). On a diurnal basis, the active storage tissues are the sapwood, with associated cambium and phloem, and the canopy. The flows in the xylem are determined by gradients of water potential and hydraulic conductance, while movement to/from the storage tissue is explained by storage volume and capacitance $(\mathrm{Q})$, i.e. change in water content per unit change in water potential $(\mathrm{Q}=\partial \mathrm{W} / \partial \psi)$.

Sap flow begins in the morning when the canopy has lost enough water for the concomitant decrease in $\psi_{1}$ to provide the required hydraulic lift. At the same time, withdrawal from sapwood storage allows transpiration to further exceed uptake by roots and thus slow the decline in $\psi_{1}$. The greater the storage relative to transpiration, the longer the delay until flow increases in the roots. Late in the day, as $\psi$ gradients reverse, storage can be replenished when water uptake exceeds transpiration. As soil water content decreases from day to day, the time for recharge of storage is delayed, depending on stomatal control, later into the evening or night. Such diurnal dynamics have been measured in many tree species (Wullschleger et al. 1998; Meinzer et al. 2001) and have revealed that storage contributes from 10 to $25 \%$ of daily transpiration. Schulze et al. (1985) working with 20-25 m Larix estimated a contribution of $16.7 \mathrm{~kg}$ from the canopy but only $1.6 \mathrm{~kg}$ from trunk. The contribution of heartwood (old xylem) is less certain and is perhaps restricted to periods of extended drought. 
Leaves at the tops of trees are the most exposed and therefore experience the greatest evaporative demand. They are also connected to the root system by the longest pathway and for both reasons are potentially subject to the greatest drop in $\psi_{1}$ relative to the root $\left(\psi_{\mathrm{r}}\right)$. The pattern of conduction in a tree, i.e. the hydraulic architecture, is therefore an important determinant of the distribution of $\psi_{1}$ throughout the canopy. Salleo et al. (1985) measured hydraulic conductivity $\left(\mathrm{m}^{2} \mathrm{~s}^{-1} \mathrm{~m}^{-2} \mathrm{MPa}^{-1}\right)$ of stem segments of 1year-old shoots (cultivar not identified) in relation to xylem conducting area, xylem vessel area, and the leaf area supported by each segment. All parameters decreased with distance along the shoot and were highly linearly correlated. Conductivity of xylem vessels was an order of magnitude greater than that of xylem area, reflecting the small vessel diameter (ca. $10 \mu \mathrm{m}$ ) and large proportion of cell-wall tissue. Vessel density varied from 250 to $400 \mathrm{~mm}^{-2}$. There was also a strong linear correlation between the leaf specific hydraulic conductivity (LSC), the rate of water flow per unit leaf area supported per unit pressure gradient and xylem area (and also vessel area) presenting an appealing view of tree hydraulic architecture with coordinated expansion of leaves and conducting capacity of the xylem. Thompson et al. (1983) had previously shown that LSC was related to stem diameter in primary, secondary, and tertiary branches of potted (4-year old, $1.5 \mathrm{~m}$ tall) plants of 'Nocellara' and 'Coratina'.

Sap flow in olive trees has been measured in the trunks (Fernández et al. 2001; Giorio and d'Andria 2002; Giorio and Giorio 2003) and in roots (Fernández et al. 2001) using sap-velocity sensors and estimates of the xylem conducting area. This work has shown that sap flow is variable at depth within the xylem, around the trunk, and from major root to major root. The observation that the root system absorbs water preferentially from moist regions is consistent with the theory of water flow in response to gradients of water potential, as is also the rapid re-activation of parts of the root system following rainfall or irrigation. Favored connections between individual stems and parts of the root system could explain the variations of flow around the trunk. This has yet to be shown in olive, but has been inferred in other species, e.g. Eucalyptus regnans (Legge 1985) by following flow patterns of dyes injected into roots. Less clear are the observed profiles of water flow in the xylem. There is a general decrease in flow with depth that is consistent with gradual occlusion of vessels as they age, perhaps caused in part by embolisms. The issues of the formation of embolisms by cavitation, their possible recovery, and their significance to drought tolerance are discussed in Section VIIA. The suggestion by Fernández et al. (2001) that the small flow recorded in the periphery of xylem tissues in water-stressed trees reflects stomatal control of transpiration of active leaves, preferentially connected to the youngest xylem vessels, requires further evaluation. Giorio and d'Andria (2002) also reported a similar form of sap-flow profile. Observations of night-time sap flow in roots are of interest to the role of capacitance in the water relations of trees, but additional associated measurements are required to establish the extent and importance of this, and other hydraulic characteristics, of olive.

One limitation of sap flow sensors in determining actual rates of transpiration is uncertainty in the dimensions of the cross-sectional area of the conducting xylem. Sap velocity probes are usually placed in one or several radial positions and the cross sectional area of the trunk is assumed to be uniform around the circumference. Observations on olive trees have shown that the apparent area of the conducting xylem varies in thickness across various diameters, casting doubts on the assumption of uniform 
cross sectional area (E. Fereres, unpublished). Giorio and d'Andria (2002) installed sap flow sensors in a 7-year orchard of 'Kalamata' $(6 \times 3 \mathrm{~m})$. There were strong linear relationships between tree transpiration $(\mathrm{T})$ and reference crop evapotranspiration $\left(\mathrm{ET}_{0}\right)$ in both rain-fed and irrigated orchards. Irrigation was set at $0.36 \mathrm{ET}_{0}$ according to the product of a crop coefficient and a cover factor, both $=0.6$. Mean $\mathrm{T}$ of individual trees at $\mathrm{ET}_{0}=5 \mathrm{~mm}$ day $^{-1}$ was recorded as 9 and $22 \mathrm{~L} \mathrm{day}^{-1}$ for rainfed and irrigated, respectively, corresponding on an orchard basis to 0.5 and $1.2 \mathrm{~mm}^{-1 a y}{ }^{-1}$. The T measured in the irrigated orchard was smaller than that calculated as $0.36 \mathrm{ET}_{0}\left(1.8 \mathrm{~mm}\right.$ day $\left.^{-1}\right)$. Cohen et al. (2001) found that sap flow sensors underestimated tree $\mathrm{T}$ by about $50 \%$ when compared with lysimeter measurements in peach.

Clearly there is much to be learned about these physiological and anatomical aspects of the water-conducting and water-storage characteristics of olive trees. Work done thus far with potted plants and small branches should be extended into the field. The daunting task of dealing with old trees can await the development of knowledge and techniques on young trees. They will present an easier target, and one that is more aligned with modern production systems. A good start would be to describe the structure of the conducting system - the hydraulic architecture of the tree (Tyree and Ewers 1991). What is the volume of the conduction system relative to canopy area? How does LSC vary from trunk to final branches? How does the capacitance of the sapwood compare with that of the canopy? How do storage and withdrawal contribute to diurnal and seasonal water status of the canopy? And inevitably, because of the potential disruption that it causes, how do these systems respond to pruning?

\section{Control of Transpiration}

There have been many studies of stomatal response to leaf water status and environment in olive (e.g. Abdel-Rahman and El-Sharkawi 1974; Natali et al. 1985; Xiloyannis et al. 1988; Fernández et al. 1993; Fernández et al. 1997; Giménez et al. 1997; Chartzoulakis et al. 1999; Moriana et al. 2002). They reveal that stomata respond in ways consistent with their role in controlling transpiration (T) and maintaining leaf water status. Leaf conductance is small, and decreases as $\psi_{1}$ falls and as vapor pressure deficit (VPD) increases. The observations of Moriana et al. (2002) in an 18-year-old orchard of 'Picual' at Córdoba are especially comprehensive. They reveal the dominant interaction of $\psi_{1}$ and VPD on $\mathrm{g}_{1}$ at midday (Fig. 3). Maximum conductance of $240 \mathrm{mmol} \mathrm{m}^{-2} \mathrm{~s}^{-1}$ at that time was recorded when midday $\psi_{1}$ exceeded $-1.65 \mathrm{MPa}$ and VPD was small (ca. 1 $\mathrm{kPa}$ ). Conductance fell with decrease in $\psi_{1}$. The response to VPD persisted in leaves in which $\psi_{1}$ exceeded $-4.0 \mathrm{MPa}$, but below this value the small $\mathrm{g}_{1}$, in leaves that were substantially water stressed was unresponsive to VPD. On a diurnal basis, $\mathrm{g}_{1}$ attained maximum levels in the early morning, and then decreased to a minimum during midday hours. In the afternoon, $\mathrm{g}_{1}$ followed stable or declining patterns depending on environmental conditions. Response to VPD is considered to operate through peristomatal transpiration and isolation of guard cell water status from the bulk leaf $\left(\psi_{1}\right)$. The observation that stomatal aperture varied from place to place on olive leaves (Loreto and Sharkey 1990) is evidence of independence of guard cells at high $\psi_{1}$. When $\psi_{1}$ declines substantially, however, it is increasingly unlikely that guard cells can remain isolated and hence independently responsive to VPD. 
The observed stomatal responses of olive are not, however, fully explained by changes in $\psi_{1}$ and VPD. For example, Moriana et al. (2002) found that maximum and midday $\mathrm{g}_{1}$ varied seasonally, even under well-watered conditions, and were also affected by fruit load. Thus olive stomatal responses to water stress cannot be interpreted using simplified physical models of the continuum of water status in trees because it appears that endogenous factors modulate responses in the long term. A similar conclusion first emerged from the analyses of interactions between $g_{1}$ and $\psi_{1}$ of fruit trees growing in the Negev desert (Schulze and Hall 1982).

In olive, the regulation of $\mathrm{g}_{1}$ below its maximum during much of the day is the cause of the small canopy conductance $\left(\mathrm{g}_{\mathrm{c}}\right)$ for the entire orchard (Villalobos et al. 2000). The impact of small canopy conductance on orchard T depends on the degree of coupling of the canopy with the atmosphere (MacNaughton and Jarvis 1983). Smooth, short canopies of field crops are not well coupled with the atmosphere and show only small reduction in transpiration as canopy conductance is reduced. In contrast, sparse, rough tree canopies, such as olive, are well coupled so a reduction in canopy conductance reduces T by a similar magnitude (Villalobos et al. 2000). Small canopy conductance of olive explains the small values of the empirical crop coefficients recommended to estimate ET of olive orchards (Orgaz and Fereres 1998; Pastor et al. 2001). At full cover $(\mathrm{CC}>0.5)$, drip-irrigated orchards experience little soil evaporation, and ET is in the range 50 to $65 \%$ of reference crop evapotranspiration $\left(\mathrm{ET}_{0}\right)$. Such values are less than those proposed for citrus (75\%) and for most tree crops (85-110\% of $\mathrm{ET}_{0}$ ) (Allen et al. 1998).

\section{MINERAL NUTRITION}

Olive, as other higher plants, requires macro- $(\mathrm{C}, \mathrm{H}, \mathrm{O}, \mathrm{N}, \mathrm{S}, \mathrm{P}, \mathrm{K}, \mathrm{Mg}, \mathrm{Ca})$ and micronutrients $(\mathrm{Fe}, \mathrm{Zn}, \mathrm{Cu}, \mathrm{Mn}, \mathrm{B}, \mathrm{Cl}$ ) in appropriate amounts for continuing growth and yield. With exception of $\mathrm{C}, \mathrm{H}$, and $\mathrm{O}$, obtained from air and water, the remainder are absorbed by roots from soil. Nitrogen deserves special attention, not just because it is the nutrient required in the greatest amounts, but also because unlike other soil-borne nutrients, it exists dominantly in the organic phase. In the soil, $\mathrm{N}$ exists in continual interaction between living organisms, dead organic matter, and the mineral forms $\mathrm{NH}_{4}{ }^{+}$and $\mathrm{NO}_{3}{ }^{-}$. Ammonium $\left(\mathrm{NH}_{4}{ }^{+}\right)$does not persist in aerobic soils and $\mathrm{NO}_{3}{ }^{-}$, a large molecule, exists dominantly in the soil solution. Three features typify the nutritional relationships of olive. First, as a perennial, it is able to mobilize and store nutrients internally, for example by withdrawal from senescing organs, especially leaves. Second, the mineral content of harvested fruit is small and thus the export of nutrients, especially from lowyielding rain-fed systems, is trivial. Third, pruning together with natural litter fall provides the possibility of significant external cycling of nutrients, including the recovery of nutrients from depth and their concentration in surface layers of the soil.

The nutrition of olive can be discussed in two ways. The first is the detection of nutrient deficiency, or in some cases toxicity, by visual symptoms and soil and/or plant tissue analysis. The application of knowledge here is on tactical fertilizer management to maintain or improve productivity. The second concerns the contribution to the long-term functioning of olive orchards by the cycling of nutrients internally within the trees and externally by litter fall, pruning, and the return of harvest residues. An understanding of nutrient cycling is required for the development of sustainable nutrient management 
strategies that have special importance to the current expansion of organic production systems.

\section{A. Deficiencies and Toxicities}

Catalogues of visual symptoms of nutrient deficiency have been published for many species and while some photographs are available for olive (Sanz Encinas and Montanes Garcia 1997; Fernández-Escobar 1998), no comprehensive catalogue has been published. Analyses of soil nutrient content are also useful in diagnosis. Caution must be expressed here, however, because in addition to substantial spatial variability within orchards, there may also be large differences between amounts and availability of individual nutrients in the soil. Soil analysis is most useful to detect the presence of extremely deficient or toxic levels of nutrients, e.g. deficiencies of $\mathrm{N}, \mathrm{P}, \mathrm{K}, \mathrm{Fe}$, and $\mathrm{B}$ or toxic levels of $\mathrm{Na}, \mathrm{Cl}$, or $\mathrm{B}$. Soil $\mathrm{pH}$ is itself a simple diagnostic test because it can predict availability of some nutrients, e.g. Mn and Fe.

The best means for detecting the nutritional status and thus the fertilizer requirements of olive orchards is by analysis of leaf nutrient concentration (FernándezEscobar 1998). While there has also been some success using flowers in other crops, only preliminary data are available for olive (Bouranis et al. 1999). For leaf analysis, care is needed in sampling, because leaf nutrient concentration varies depending upon leaf age, position on tree, weather conditions, and fruit load (see e.g. Fernández-Escobar et al. 1999; Sibbett and Ferguson 2002). Consequently, a standardized sampling procedure is required. For olive, this currently requires the collection around PS71 to PS74 of two to three current year's leaves, including petioles, from the base to the middle of non-fruiting shoots at various positions around the canopy. Time of leaf collection is not well defined and some data suggest that nutrient concentrations change during July but are more stable in October (M. Pastor, pers. comm.). To assess an orchard for nutritional requirements, a number of trees should be sampled. Sampling should avoid atypical trees, except for the specific purpose of diagnosis. Comparison with diagnostic data such as presented in Table 1 can, together with observations of visual symptoms, soil analysis, and local experience provide a basis for fertilizer recommendations. Care should be taken in assessing fertilizer $\mathrm{N}$ needs based on short-term field trials, because olive, as most perennials that evolved in Mediterranean environments, has the capacity to mobilize $\mathrm{N}$ to meet its small needs for several years before leaf deficiency or a response to the addition of $\mathrm{N}$ can be detected.

The objective of fertilization is to maintain or improve the nutrient status of the tree, so as to maintain or increase crop productivity. It can be achieved, depending on individual nutrient and cost, by direct application to soil (either broadly or directed to each individual trees) or more efficiently through injection into a drip irrigation system (fertigation), application by spray to canopies $(\mathrm{Fe}, \mathrm{B}, \mathrm{N})$, or by direct injection $(\mathrm{Fe})$ into tree trunks (Fernández-Escobar et al. 1993). All these methods are appropriate and are used for olive.

\section{B. Extraction and Cycling of Nutrients in Olive Orchards}

The available data on nutrient concentrations in the various organs of olive are variable. There are many data on leaves and fruit, one study on inflorescences (Bouranis et al. 1999) but nothing, to our knowledge, on branches, trunk, and roots. Data presented in the 
studies of nutrient uptake of young orchards (Celano et al. 1999; Xiloyannis et al. 2002) are only marginally useful. A compilation of data (Table 2), together with information on organ biomass, can be used to evaluate a range of issues in nutrient cycling in relation to orchard function and management. These include what is present in trees, how much is required for each year's growth, how much is cycled internally, what is removed by harvest, and what is cycled externally by litter fall and pruning. As olive production becomes more intensive, the nutrient dynamics and requirements contrast sharply with those of traditional olive culture.

The data in Table 2 allow estimates of extraction of nutrients in harvested fruit. It is small for $\mathrm{P}\left(1.1 \mathrm{~kg} \mathrm{t}^{-1}\right)$, greater for $\mathrm{N}$ (7.2), and greatest for $\mathrm{K}(10.9)$. Natural net accretion of $\mathrm{N}$ from storms and dust could account for extraction by $1 \mathrm{t} \mathrm{ha}^{-1}$ yield, but there is no such replacement for $\mathrm{K}$, which is extracted in greater quantities, pointing to the need for care in developing $\mathrm{K}$ fertilization strategies. From a physiological perspective, there is no information on the role of $\mathrm{K}$ in fruit growth of olive but by comparison with other plants $\mathrm{K}$ must play many roles in olive physiology, including some critical ones in the water relations through its osmotic activity.

There are few individual studies of the internal cycling of nutrients in olive. Exceptions are the comparisons of nutrient concentrations of mature and senescent leaves of 12-y-old 'Picual' (Fernández-Escobar et al. 1999) and observations of the apparent movement of B from young leaves to flowers during anthesis (Delgado et al. 1994; Perica et al. 2002). The data in Table 2 permit an analysis of the internal nutrient cycling from leaves as they senesce because in this case the authors report that leaf mass $(85 \mathrm{mg})$ did not change from maturity to the senescent condition. Leaves live for 2 to 3 years so ca. $40 \%$ of the canopy is lost (and replaced) each year. The biggest recorded change is for $\mathrm{N}$. For an orchard, $\mathrm{N}$ withdrawal will be around $12 \mathrm{~kg} \mathrm{ha}^{-1}$ per unit loss of leaf area index $(\mathrm{LAI})\left(\mathrm{SLM}=200 \mathrm{~g} \mathrm{~m}^{-2}\right)$ which amounts to $39 \%$ of the $\mathrm{N}$ supply required for leaf replacement. External cycling of $\mathrm{N}$ by leaf fall is around $19 \mathrm{~kg} \mathrm{LAI}^{-1}$ but not all of this would be available to the tree after leaf fall. Severe pruning that removes up to $30 \%$ of the leaf canopy (with associated branches) is an infrequent intervention, but one that has substantial effects on nutrient and water demand as well as on nutrient cycling. The impact on nutrient cycling would depend on whether the pruned branches are removed from the orchard, burnt in place, or chopped and left on the soil surface, as in recommended organic farming practices. Information on nutrient contents of wood and on external recycling is needed to make complete analyses.

\section{CARBON ACCUMULATION}

Carbon accumulation is the net result of assimilation of $\mathrm{CO}_{2}$ from the atmosphere by photosynthesis and subsequent dissimilation of part of that by respiration. The remainder is retained as the major component of biomass. Leaves are the dominant organs of assimilation in olive while all living tissues respire. Fruit play a minor role in assimilation but have high respiration rates consistent with their intense metabolic activity in lipid synthesis (see Section VID). Respiration provides energy in appropriate forms (e.g. ATP, NADH) for all metabolic processes ranging from maintaining integrity of membranes, transport and interconversions of nutrients, through to providing the energy for the construction of new organs. While there is no single chemistry of respiration (release of $\mathrm{CO}_{2}$ ), it is useful to consider it in two components. The first is 
maintenance respiration (MR) that provides the energy that sustains existing organs and the second, constructional respiration (CR) that provides the energy to build the complex chemical compounds of new tissues. Maintenance respiration is expressed as $\mathrm{CO}_{2}$ release per unit tissue mass per unit time and shows a major response to temperature, essentially doubling for each $10^{\circ} \mathrm{C}$ rise in temperature. In contrast, $\mathrm{CR}$ is expressed as $\mathrm{CO}_{2}$ release per unit of growth, so although the underlying metabolic processes respond to temperature, CR depends upon the amount and nature of the new growth. For example, polymerization of sugar to starch or cellulose requires less energy that the construction of proteins or fats. This gives rise to the notion of glucose requirement of growth $(\mathrm{GR}=\mathrm{g}$ glucose $\mathrm{g}^{-1}$ dry matter produced or maintained) that can be calculated from chemical composition (Penning de Vries et al. 1974) or elemental analysis (McDermitt and Loomis 1981). Merino (1987) used these methods to compare the cost of growing and maintaining leaves of a range of Mediterranean species. Olive, with GR for growth $=$ $1.66 \mathrm{~g}_{\text {glucose }} \mathrm{g}^{-1}$ dry matter (d.m.), was greater than the mean for tree species (1.54)

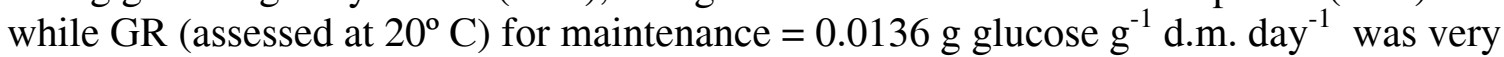
close to the mean (0.0138).

\section{A. Leaf Photosynthesis}

Photosynthesis (A) in olive proceeds by the $C_{3}$ pathway (Bongi et al. 1987b) and, in common with many other shrub and tree species, achieves a lower maximum rate $\left(\mathrm{A}_{\max }\right)$ at higher saturating photon flux density (800 to $1000 \mu \mathrm{mol} \mathrm{m}^{-2} \mathrm{~s}^{-1}$ ) (Bongi and Long 1987; Bongi and Loreto 1989; Bongi and Palliotti 1994; Proietti and Palliotti 1997) with a smaller quantum efficiency $(\varphi)$ and higher internal $\left[\mathrm{CO}_{2}\right]$ under optimal conditions and ambient $\left[\mathrm{CO}_{2}\right]$ (ca. $350 \mu \mathrm{mol} \mathrm{mol}{ }^{-1}$ ) than herbaceous $\mathrm{C}_{3}$ (crop) species.

The highest $\mathrm{A}_{\max }$ of $22 \mu \mathrm{mol} \mathrm{CO} \mathrm{Cm}^{-2} \mathrm{~s}^{-1}$ was recorded for 'Coratina' grown outdoors in pots (Angelopoulos et al. 1996). Other studies also report reasonably high rates, e.g. $19 \mu \mathrm{mol} \mathrm{CO} \mathrm{CO}^{-2} \mathrm{~s}^{-1}$ in an 18-year-old orchard of 'Picual' (Moriana et al. 2002), $18 \mu \mathrm{mol} \mathrm{CO} \mathrm{m}^{-2} \mathrm{~s}^{-1}$ in mature 'Picual' (Giménez et al. 1997), 15 to $16 \mu \mathrm{mol} \mathrm{CO}_{2}$ $\mathrm{m}^{-2} \mathrm{~s}^{-1}$ for 'Koroneiki' and 'Amphissis' (Chartzoulakis et al. 2002), $14 \mu \mathrm{mol} \mathrm{CO}_{2} \mathrm{~m}^{-2} \mathrm{~s}^{-1}$ for 'Frantoio' and 'Maurino' (Proietti and Palliotti 1997), 'Kalamon' (Giorio et al. 1999), and 'Mastoidis' (Chartzoulakis et al. 1999). These results contrast with much smaller $\mathrm{A}_{\max }$ recorded in other studies, when plants were grown in artificial environments or at low irradiance. High irradiance is required for complete development of leaf anatomy and carboxylation capacity for photosynthesis. Thus, $\mathrm{A}_{\max }$ was $7.7 \mu \mathrm{mol} \mathrm{CO}_{2} \mathrm{~m}^{-2} \mathrm{~s}^{-1}$ for 'Rajo' (Bongi and Long 1987) and $5.4 \mu \mathrm{mol} \mathrm{CO} \mathrm{Cm}^{-2} \mathrm{~s}^{-1}$ for 'Manzanilla', 'Dolce Agogia', 'Coratina', and 'Leccino' (Bongi et al. 1987a) in controlled environments. Given the variability in $\mathrm{A}_{\max }$ that has been recorded in various published studies, it is only possible to make effective comparisons between cultivars when they are grown together under optimal conditions and measured with the same equipment. One example is that of Chartzoulakis et al. (2002) who established differences in $\mathrm{A}_{\max }(\mathrm{p}<0.05)$ among five cultivars, viz. 'Koroneiki' 15.6, 'Mastoides' and 'Amphissis' 14.5, 'Kothreiki' and 'Megaritiki' 13.5, and 'Kalamata' $10.4 \mu \mathrm{mol} \mathrm{CO} \mathrm{Cm}^{-2} \mathrm{~s}^{-1}$, respectively. A second (Loreto et al. 2003), working with 1-year-old potted plants, established extreme differences ranging from $17 \mu \mathrm{mol} \mathrm{CO} \mathrm{CO}_{2}^{-2} \mathrm{~s}^{-1}$ for 'Kerkiras' to $4 \mu \mathrm{mol} \mathrm{CO}_{2} \mathrm{~m}^{-2} \mathrm{~s}^{-1}$ for 'Chalkidikis'. Others were intermediate, 'Valanolia' at 7.5 and 'Throubolia', 'Adramitini' and 'Agouromanaki' at $6 \mu \mathrm{mol} \mathrm{CO}_{2} \mathrm{~m}^{-2} \mathrm{~s}^{-1}$. Such intraspecific variations in $\mathrm{A}_{\text {max }}$ are greater 
than those found in most crop plants, suggesting the existence of cultivars with low $\mathrm{A}_{\max }$ but always with concern over the effect of growing environment. Not surprisingly, all major cultivars have relatively high $\mathrm{A}_{\max }$ values.

Quantum efficiency is the ratio $\left(\mathrm{mol} \mathrm{mol}^{-1}\right)$ of photosynthesis to absorbed PAR at low irradiance because under that condition, with other factors optimal, $\left[\mathrm{CO}_{2}\right]$ does not limit photosynthesis. Two papers from Bongi and collaborators offer conflicting estimates of $\varphi$. The value of 0.026 reported by Bongi and Long (1987) for 'Rajo' seems more consistent with developing views of olive photosynthesis, restricted as it is by substantial inactive absorption of PAR in the sclerophyllous leaves and a possibly inefficient photochemistry. The matter does require further experimental evaluation, however, because the above value conflicts with a value of 0.052 reported for 'Coratina', 'Manzanilla', 'Dolce Agogia', and 'Leccino' (Bongi et al. 1987a) that would make olive comparable with herbaceous $\mathrm{C}_{3}$ crop species (Ehleringer and Pearcy 1993).

The ratio of $\mathrm{CO}_{2}$ concentration within the leaf to that outside $\left(\mathrm{C}_{\mathrm{i}} / \mathrm{C}_{\mathrm{a}}\right)$ reflects the relative magnitude of gaseous conductance from atmosphere to leaf spaces relative to the total pathway from atmosphere to the sites of fixation within the chloroplast where $\left[\mathrm{CO}_{2}\right]$ approaches zero. High values of $\mathrm{C}_{\mathrm{i}} / \mathrm{C}_{\mathrm{a}}$ indicate that low internal (liquid phase) conductance is a significant limitation to photosynthesis. In olive, recorded values of $\mathrm{C}_{\mathrm{i}} / \mathrm{C}_{\mathrm{a}}$ at high $\mathrm{A}_{\max }$ generally exceed 0.75 (Bongi and Long 1987; Bongi et al. 1987a; Bongi and Loreto 1989; Proietti and Palliotti 1997; Minnocci et al. 1999), values common to $\mathrm{C}_{3}$ species. In physiological experiments, measurements of the relationship between $A$ and $C_{i}$ are also used to examine the relative limitations imposed by stomata, internal conductance of $\mathrm{CO}_{2}$ transfer, and carboxylation under various experimental conditions.

The explanation of these photosynthetic characteristics of olive is found in three major features of the anatomy and morphology of the leaf. First, the anatomical basis of the low conductance to gaseous flow across the leaf surface was described earlier.

Second, the internal anatomy, with closely packed chlorenchyma, provides little space for gaseous diffusion inside the mesophyll. A stereological analysis that assessed the extent of packing in 'Ascolana' calculated an internal cell wall conductance to $\mathrm{CO}_{2}$ transport of $0.11 \mathrm{~mol} \mathrm{~m}^{-2} \mathrm{~s}^{-1}$ that is one quarter of the corresponding value for wheat (Bongi et al. 1987b). The interplay of leaf surface and internal conductances explains the high $C_{i} / C_{a}$ ratio that characterizes olive photosynthesis. Whereas low wall conductance is an effective mechanism to reduce loss of internal water under severe stress it always limits photosynthesis by restricting the supply of $\mathrm{CO}_{2}$ to the sites of fixation. Third, the tightly packed mesophyll, together with the additional structural tissue that together provide the rigid sclerophyllous leaves characteristic of olive, result in low chlorophyll and $\mathrm{N}$ content (see Table 2) and therefore more inactive absorption of PAR than occurs in herbaceous (crop) $\mathrm{C}_{3}$ species. Inactive adsorption and low internal conductance explain the low $\mathrm{A}_{\max }$ and the high PAR needed to achieve it. Internal PAR absorption also explains why olive leaves have greater photosynthesis when illuminated at low irradiance from both sides. Proietti and Palliotti (1997), working with 'Frantoio', proposed light compensation points of 30 and $50 \mu \mathrm{mol} \mathrm{m} \mathrm{m}^{-2} \mathrm{~s}^{-1}$ for leaves irradiated on both, or only on the upper surface, respectively. These responses have significance within olive canopies where the 
proportion of reflected PAR increases with depth. Illumination from both sides decreases the light compensation point, i.e. the threshold irradiance for positive net photosynthesis.

The effect of peltate trichomes, especially common on the lower surfaces of olive leaves, on photosynthesis is controversial. Theory would propose a reduction in photosynthesis resulting from greater reflectivity. Consistent with this, Grammatikopoulos et al. (1994) report an increase of $11 \%$ (76 to $84 \%$ ) in PAR absorptance following trichome removal in an unspecified cultivar, not all of which would be actively absorbed by chlorophyll within the leaf. On this basis, one would expect a small increase in A at low irradiance gradually diminishing as irradiance approaches saturation. This may explain why comparisons of A between leaves with and without trichomes (Grammatikopoulos et al. 1994; Proietti and Palliotti 1997) have revealed no differences. Those comparisons were mostly made at high irradiance when responses should not be expected. Further, the wide range of measurements, with confidence levels at around $25 \%$ of the means, prevented detection of small differences in the few measurements taken at low irradiance (Proietti and Palliotti 1997).

Changes in the external environment, or internal factors that affect the photosynthetic system of the leaf, will reduce A below $\mathrm{A}_{\max }$. Photosynthesis can be reduced by stomatal closure, decreased internal transport of $\mathrm{CO}_{2}$ to the sites of fixation, and/or by reduced carboxylation. The effects may be transitory, as can be seen in diurnal patterns of photosynthesis that recover from day to day. If they are persistent, however, they may be of great importance because olive leaves usually remain on trees for two years or more and can maintain a stable photosynthetic capacity until the final stages of senescence (Bongi et al. 1987a). The most important factors that affect photosynthesis in the field are irradiance, temperature, and water status. Others of significance are salinity and photo-inhibition, and of increasing interest, atmospheric pollutants, UV-B radiation, and $\left[\mathrm{CO}_{2}\right]$.

1. Effects of Temperature. The optimum temperature for net photosynthesis (A) is around $28^{\circ} \mathrm{C}$ (Bongi et al. 1987a; Chartzoulakis et al. 2002) with high rates maintained in the range 20 to over $30^{\circ} \mathrm{C}$. In this temperature range, $\mathrm{g}_{1}$ is maintained high and respiration rates are small relative to assimilation. Bongi et al. (1987a) compared A of four cultivars, chosen to represent distinct thermal zones of olive production in the Mediterraean region ('Manzanilla' - warm Spanish area, 'Dolce Agogia' - cold Italian area, 'Coratina' - medium-warm Italian area, and 'Leccino' - medium-warm area), in response to temperatures of $10,20,30$ and $40^{\circ} \mathrm{C}$. The optimum temperature was around $28^{\circ} \mathrm{C}$ for all cultivars, but with differences at the extremes. While all cultivars displayed a similar and major reduction of $\mathrm{A}$ at $10^{\circ} \mathrm{C}$ (to $10 \%$ of maximum) and significant $\mathrm{A}$ at $40^{\circ} \mathrm{C}$ ( $>50 \%$ of maximum), 'Manzanilla', maintained highest $\mathrm{A}$ at $40^{\circ} \mathrm{C}(80 \%$ of maximum). While the performance of 'Manzanilla' at high temperature is consistent with its region of origin, the complete characterization of temperature responses must include assessing acclimation to low and high temperatures when grown in the field. The role of acclimation in olive must be critical, given the wide range of temperatures experienced seasonally by this crop within the various environments where it is grown.

2. Effects of Water Deficit. Many papers have dealt with the reduction of A under and following water stress ( Xiloyannis et al. 1988; Angelopoulos et al. 1996; Giménez et al. 1997; Giorio et al. 1999; Nogués and Baker 2000; Moriana et al. 2002). Taken together, 
these studies show that A is significantly reduced by water deficit and that stomatal closure plays a major role. There are, however, non-stomatal effects that may persist after prolonged water shortage.

Moriana et al. (2002) provided a comprehensive analysis of measurements taken on irrigated and droughted trees over the summer-autumn period in an 18-year-old orchard of 'Picual' at Córdoba, Spain. Midday xylem water potential ( $\psi_{\mathrm{x}}$, measured as $\psi_{1}$ of covered leaves) in rain-fed trees fell to $-8.0 \mathrm{MPa}$ and VPD reached $7 \mathrm{kPa}$. For all measurements at saturating irradiance and $\psi_{\mathrm{x}}>-4.5 \mathrm{MPa}, \mathrm{A}$ at $350 \mu \mathrm{mol} \mathrm{CO} \mathrm{mol}^{-1}$ was linearly related to $\mathrm{g}_{1}$. At lower $\psi_{\mathrm{x}}$, there was clear evidence of non-stomatal limitation. A similar conclusion was drawn by Angelopoulos et al. (1996) whose data, on 2-year-old potted plants of 'Coratina' grown outdoors (Fig. 4), display a two-part relationship between maximum $\mathrm{A}$ and $\mathrm{g}_{1}$. Stressed plants had $\mathrm{A}<5 \mu \mathrm{mol} \mathrm{CO}_{2} \mathrm{~m}^{-2} \mathrm{~s}^{-1}$ and did not conform to the general linear relationship but displayed smaller A than controls at equivalent $\mathrm{g}_{1}$. The diurnal patterns of A under water deficit also follow closely those reported by Moriana et al. (2002). As stress intensified, maximum A was observed earlier in the morning and the rate at midday gradually decreased. Contrary to the variability in A among cultivars in response to salinity (see below), there is no evidence of intraspecific variation in the response of A to water deficits.

3. Effects of Salinity. Accumulation of salt in leaves reduces A at concentrations below those at which visual symptoms are evident, and well below those that cause leaf drop. Salt is carried from roots to leaves in the transpiration stream so that plants have decreasing salt concentration from old to young leaves. This explains why effects on A and visual symptoms appear first in old leaves. Thus, Bongi and Loreto (1989), in experiments with 3-year-old plants of 'Rajo', exposed to external $\mathrm{NaCl}$ concentration of $250 \mathrm{mM}$ in hydroponics for up to 90 days, recorded leaf salt profiles from apex to base of 46 to $90 \mathrm{mM}$ at 25 days and from 75 to $990 \mathrm{mM}$ at 90 days compared with controls exposed to $35 \mathrm{mM}$ salt. Leaf photosynthesis was reduced by $18 \%$, leaf growth ceased, and there was $50 \%$ leaf drop when tissue salt exceeded $80 \mathrm{mM}$. Salt reduced A by decreasing $\mathrm{g}_{1}$, decreased internal conductance (smaller $\mathrm{g}_{\mathrm{w}}$ ), and effects at the photosynthetic sites (Bongi et al. 1987a; Tattini et al. 1997; Centritto et al. 2003; Loreto et al. 2003). The smaller internal conductance results from leaf thickening and greater water content. Measurements of chlorophyll fluorescence revealed irreversible damage at salt levels exceeding $200 \mathrm{mM}$.

Differential responses of A between cultivars to external salinity can derive from exclusion/sequestration of salt by the roots as well as by ability to sustain $\mathrm{A}$ in response to increasing leaf salt concentration. Both responses have been established in olive. Tattini et al. (1997) concluded that the effect of internal salt $(250 \mathrm{mM})$ was greater in 'Frantoio' than in 'Leccino', with threshold values for 50\% reduction of A at 146 and 275 $\mathrm{mM}$, respectively, in the two cultivars. This conclusion is, however, dominated by a couple of data points (their Fig. 5) and the true difference may be much smaller. In contrast, A in young leaves was reduced by $60 \%$ by $200 \mathrm{mM}$ salt in 'Koroneiki', 'Mastoides', and 'Amphissis', by 40\% in 'Kothreiki' and 'Megaritiki', and by $20 \%$ in 'Kalamata' (Chartzoulakis et al. 2002). No difference was detected, however, in the relationship between A and leaf tissue salt concentration, so the differences in tolerance between these cultivars must derive from exclusion/sequestration of salt at the root level. 
Certainly, 'Kalamata', the least affected cultivar, maintained the lowest leaf salt concentration across the range of external salt and showed no visual symptoms over the 5-month period of treatment. It is significant that cultivars with the smallest $\mathrm{A}$ and $\mathrm{g}_{1}$ under control conditions, 'Kalamata' in this study and 'Chalkidikis' in that of Loreto et al. (2003), were also least affected by salt.

The most interesting feature of these experiments is that the response of A does not coincide with current views on the relative salt tolerance of olive cultivars based on growth and performance data as reviewed by Gucci and Tattini (1997) (see Section VIIC). 'Frantoio' is considered more salt tolerant than 'Leccino' but A of 'Frantoio' appears the more sensitive to internal salt. Smaller $g_{1}$ and transpiration could certainly contribute to restricting salt load but, as with 'Kalamata', the major component of salt tolerance likely resides in the ability of the root system to exclude salt from the xylem flow. 'Kalamata' was not recorded as salt-tolerant (Gucci and Tattini 1997) but 'Megakaritiki' that was, also showed major reduction in A in the experiments reported above (Chartzoulakis et al. 2002).

4. Photo-inhibition. Any stress that reduces the ability of leaves to dissipate excitation energy through photosynthetic reduction of carbon dioxide increases the excess energy in the leaf and the potential for damage to the light reactions of photosynthesis and the development of reducing power. Photo-inhibition is most likely at high irradiance and may have long-lasting effects on photosynthetic performance. Photo-inhibition is potentially important in olive when photosynthesis is limited by high temperature and water shortage in summer and by low temperature in winter (Pavel and Fereres 1998). Photo-inhibition can be detected when photosynthesis is not maintained at fixed conditions of irradiance, $\left[\mathrm{CO}_{2}\right]$, leaf temperature, and $\mathrm{g}_{1}$. It can also be detected by measuring, chlorophyll content, quantum efficiency $(\varphi)$, and by evaluating the condition of photo-system II (PSII) in chloroplasts by measuring leaf fluorescence. Two studies reveal aspects of these responses in olive.

Bongi and Long (1987) studied the effect of low and high temperature on nonstomatal responses of photosynthesis of potted plants in controlled environments. Attached leaves of 'Rajo' were exposed to $5^{\circ} \mathrm{C}$ for up to $12 \mathrm{hr}$ at low $\left(95 \mu \mathrm{mol} \mathrm{m} \mathrm{s}^{-2}\right)$ and high $\left(1850 \mu \mathrm{mol} \mathrm{m} \mathrm{m}^{-2} \mathrm{~s}^{-1}\right)$ irradiance and VPD $=0.4 \mathrm{kPa}$ and then allowed to recover for $24 \mathrm{hr}$ under low irradiance $\left(95 \mu \mathrm{mol} \mathrm{m} \mathrm{m}^{-2}\right)$ at $26^{\circ} \mathrm{C}$. Treatment in low and high irradiance reduced both $\varphi$ and $\mathrm{A}_{\max }$ by 10 and 50\%, respectively. Non-stomatal effects were responsible for half of the effect on $\mathrm{A}_{\max }$. Leaves that had been treated for $12 \mathrm{hr}$ in low irradiance recovered photosynthesis completely within a few hours but those treated at high irradiance did not. Leaves that were recovering from chilling at high irradiance had far more damage when chilled a second time. When entire plants were chilled, the effects on individual leaves were more severe. Treatment of individual leaves at $38^{\circ} \mathrm{C}$ for up to $7 \mathrm{hr}$ in low irradiance produced no significant effect on $\varphi$ when returned to $26^{\circ} \mathrm{C}$. In contrast, leaves subjected to $38^{\circ} \mathrm{C}$ at high irradiance suffered reductions in $\varphi$ of $25 \%$ after $1 \mathrm{hr}$ and $75 \%$ after $3 \mathrm{hr}$. In both cases, however, recovery was complete after 3 to $5 \mathrm{hr}$ in low irradiance at $26^{\circ} \mathrm{C}$.

Angelopoulos et al. (1996) studied potted plants ('Coratina') subjected to various watering regimes outdoors during the summer. Analysis of A vs. $g_{1}$ revealed the existence of non-stomatal limitations in stressed plants that were confirmed by 
measurements of chlorophyll fluorescence. Both well-watered and stressed plants had greatest $\mathrm{A}$ in the morning. Rates fell during the morning, especially rapidly in stressed plants. All leaves had increasing fluorescence during the day, and while the control plants recovered in the evening, the stressed plants did not. These non-stomatal effects were, therefore, both transient and persistent. Perhaps we find here the reason for low $\mathrm{A}_{\max }$ measured in some experiments. For example Giorio et al. (1999) made measurements at $2000 \mu \mathrm{mol} \mathrm{m} \mathrm{m}^{-2}$, well above that $\left(800\right.$ to $\left.1000 \mu \mathrm{mol} \mathrm{m} \mathrm{s}^{-1}\right)$ required for saturation.

Protection against photoinhibition caused by excess excitation energy may be achieved directly in the chlorophyll carotenoid-binding antennae complex of photosystem II leading to smaller $\varphi$. In a comparison with Eucalyptus globulus, Quercus suber and $Q$. ilex, olive (cultivar not specified), with the smallest A, also displayed the greatest concentration of carotenoid pigments, and these increased during the summer (Faria et al. 1998). The high levels of carotenoids and the seasonal variation are consistent with adaptation in olive to low A, allowing diversion of excess excitation energy into the electron transport chain to match the consumption of its products with supply from the Calvin cycle. In this way, the danger of photo-inhibition may be minimized.

5. Atmospheric Changes. Measurements have also been reported of the effect of increasing levels of $\mathrm{CO}_{2}, \mathrm{UV}-\mathrm{B}$ radiation, and industrial pollution $\left(\mathrm{O}_{3}\right.$ and $\left.\mathrm{SO}_{2}\right)$ on photosynthesis in olive.

Carbon Dioxide $\left(\mathrm{CO}_{2}\right)$. Increasing $\left[\mathrm{CO}_{2}\right]$ to double current levels of ca. $350 \mu \mathrm{mol} \mathrm{mol}{ }^{-1}$ will increase leaf photosynthesis for the same transpiration rate, and therefore increase transpiration efficiency (TE), unless there is an accompanying reduction in $\mathrm{g}_{1}$. Leaf conductance $\left(\mathrm{g}_{1}\right)$ responds to changes in stomatal morphology, i.e. density and size, and such responses to increasing $\left[\mathrm{CO}_{2}\right]$ have been measured among a range of species, with differences also established between cultivars. For olive, Tognetti et al. (2001, 2002) have measured leaf photosynthetic characteristics in 'Frantoio' and 'Moraiolo' after 7 months exposure to 560 and $360 \mu \mathrm{mol} \mathrm{CO} \mathrm{mol}^{-1}$ For both cultivars, $\mathrm{A}_{\max }$ increased, stomatal density and $\mathrm{g}_{1}$ decreased, but $\mathrm{C}_{\mathrm{i}} / \mathrm{C}_{\mathrm{a}}$ remained constant, all in response to higher $\left[\mathrm{CO}_{2}\right]$. This $\mathrm{C}_{\mathrm{i}} / \mathrm{C}_{\mathrm{a}}$ ratio reveals that increased carboxylation capacity was offset by reduced gaseous diffusion but the net effect was a major increase in TE. The two cultivars responded differently. $\mathrm{A}_{\max }$ increased more in 'Moriaolo' than in 'Frantoio' (44 vs. $31 \%$ ) but reductions in stomatal density were similar in both cultivars (-11 v. $-9 \%)$ and both cultivars had similar decreases in $\mathrm{g}_{1}(-31 \%)$. The net result of changes to photosynthesis and transpiration was a greater response in TE by 'Frantoio' than in 'Moriaolo' (94 v. 73\%). Tognetti et al. (2001) also reported that $A_{\max }$ of both cultivars increased to $31 \mu \mathrm{mol} \mathrm{m} \mathrm{m}^{-2} \mathrm{~s}^{-1}$ at $\mathrm{C}_{\mathrm{i}}=1000 \mu \mathrm{mol} \mathrm{CO} \mathrm{mol}^{-1}$ for plants acclimated at both 360 and $550 \mu \mathrm{mol} \mathrm{mol}^{-1}$. This provides an interesting comparison with the measurements of $\mathrm{A}_{\max }$ under current ambient conditions reported previously, and also suggests that down regulation of $A_{\max }$, reported for many species following exposure to high $\mathrm{CO}_{2}$, either does not occur in olive or would occur only after a longer period of exposure. The long life of olive leaves, 2 to 3 years, is likely critical to such acclimation.

These large differences of $\mathrm{A}_{\max }$ at the leaf level are not expected to translate to similar differences in growth and productivity because processes at higher levels of organization in the plant play further determining roles. 
$U V-B$ Radiation. A number of studies conclude that olive is unlikely to be affected by UV-B radiation that increases with depletion of stratospheric ozone (Karabourniotis et al. 1992; Liakoura et al. 1999; Nogués and Baker 2000). These studies covered a range of cultivars and up to four times the current levels of UV-B radiation $\left(6 \mathrm{~kJ} \mathrm{~m}^{-2} \mathrm{~d}^{-1}\right)$ experienced in the Mediterranean Region. Nogués and Baker (2000) recorded reduced A at high UV-B due to stomatal closure, while other observations (Karabourniotis et al. 1992; Liakoura et al. 1999) revealed significant protection from the UV-B absorbing capacity of the peltate layers (60\% at $310 \mathrm{~nm}$ for 'Koroneiki'). Other work has recorded stomatal effects on $\mathrm{A}_{\max }$ and, in the case of de-haired leaves, persistent damage to exposed epidermal and guard cells (Grammatikopoulos et al. 1994). That work was, however, performed at a very high UV-B $\left(5.9 \mathrm{~W} \mathrm{~m}^{-2}\right)$ and although applied only during the measurement of photosynthesis at PAR $=900 \mu \mathrm{mol} \mathrm{m}^{-2} \mathrm{~s}^{-1}$ may not, therefore, be relevant to current concerns about environmental effects of increasing UV-B radiation.

Ozone $\left(\mathrm{O}_{3}\right)$ and Sulphur Dioxide $\left(\mathrm{SO}_{2}\right)$. Ozone is a major atmospheric pollutant in the Mediterraean Basin where significant concentrations in the range 70 to $100 \mathrm{vppb}$ have been recorded for several consecutive months, including large areas away from pollution sources (Vitagliano et al. 1999). These gases are able to enter leaves, be absorbed by the liquid phase, and interfere with metabolism. Photosynthesis can be reduced by both stomatal and non-stomatal effects and can occur before visual symptoms are evident. There is evidence of significant effects on photosynthetic productivity in local areas.

Similar effects have been reported with $\mathrm{O}_{3}$ by Minnocci et al. (1999) and Sebastiani (2002). Six-year old potted plants of 'Frantoio' and 'Moraiolo' were exposed daily to 3,50 , and $100 \mathrm{vppb} \mathrm{O}_{3}$ for $5 \mathrm{hr}$ over a period of 18 months. $\mathrm{A}_{\max }$ of newly developed leaves was reduced in both cultivars but more markedly in 'Frantoio' (reductions to 35 and $24 \%$ of control of $16 \mu \mathrm{mol} \mathrm{CO} \mathrm{Cm}^{-2} \mathrm{~s}^{-1}$ at 50 and $100 \mathrm{vppb}$, respectively) than in 'Moraiolo' (comparable values 35 and $69 \%$ of $13 \mu \mathrm{mol} \mathrm{CO} \mathrm{Cm}^{-2} \mathrm{~s}^{-1}$ ). The effect in both cultivars was mediated entirely by reduction in mesophyll photosynthetic capacity, except for 'Moraiolo' at $50 \mathrm{ppb}$, which also experienced reduced leaf conductance $\left(\mathrm{g}_{1}\right)$. The recovery of $\mathrm{A}_{\max }$ in 'Moraiolo' at $100 \mathrm{ppb}$ was a consequence of greater $\mathrm{g}_{1}$.

In the case of $\mathrm{SO}_{2}$, 'Frantoio' and 'Moraiolo' were subjected to five months exposure to $\mathrm{SO}_{2}$ at up to $100 \mathrm{ppb}$ (Giorgelli et al. 1994). No visual symptoms were recorded in either cultivar, but they did have different anatomical and physiological responses. In 'Frantoio', $A_{\max }$ decreased by $38 \%$ at $100 \mathrm{vppb}$ but was unaffected in 'Moraiolo. Leaf thickness decreased significantly in both cultivars, by a maximum of 15 and 9\%, respectively, in 'Frantoio' and 'Moraiolo'. There was also a reduction in stomatal density and size that was slightly greater in 'Frantoio' than in 'Moraiolo'.

\section{B. Interception of Radiation}

The extensive results on leaf photosynthesis contrast with the little information available on the photosynthetic performance of tree canopies or entire orchards. Such work, combined with measurements of the efflux of $\mathrm{CO}_{2}$ from the soil, is critical to understanding the role of physiological responses at leaf and lower levels of organization that underlie the environmental adaptation and productivity of olive. Measurements of the $\mathrm{CO}_{2}$ balance of individual trees can be made within transparent chambers, and of 
entire orchards, by meteorological techniques that establish the flux of $\mathrm{CO}_{2}$ into the canopy. Efflux of $\mathrm{CO}_{2}$ from the soil (respiration of root and soil) can be collected in various ways. Models of canopy photosynthesis then offer the best opportunity to synthesize these data and assess the importance of cultivar, weather and management on productivity. The first step in productivity analysis, however, is to assess the interception of radiation.

In olive orchards, individual trees usually have separated canopies, widely in traditional orchards to manage water demand, and more closely in modern high-density orchards to provide space between rows for the entry of machinery for management operations. The important consideration is the balance between the total amount of radiation intercepted that determines growth, and its distribution within the canopy that determines flowering and the formation and filling of fruit. This horizontally nonhomogeneous distribution of foliage in olive orchards contrasts with that of most field crops for which simple descriptions of canopy structure (leaf area index, LAI, and extinction coefficient, k) are generally adequate for the analysis and management of radiation and energy exchanges. The canopies of olive orchards are more appropriately defined by combinations of tree spacing (row and inter-row, $\mathrm{m}$ ), tree height $(\mathrm{m})$, row orientation (degrees $\mathrm{N}$ ), vertical projection of canopy cover (CC), and canopy volume $\left(\mathrm{m}^{3} \mathrm{ha}^{-1}\right)$. Villalobos et al. (1995) have shown how many of these parameters can be measured non-destructively by analysis of light interception in isolated olive trees and orchards using the gap-inversion method. At low canopy cover, trees intercept more incident radiation per unit leaf area than field crops of lower stature, and consequently shade more of the soil surface than herbaceous crops, except at high solar angles. This behavior is especially pronounced for evergreen trees in the temperate latitudes, where solar angles are low for several months of the year.

The relationship between interception of radiation and canopy structure varies throughout the year depending upon solar position and cloudiness (i.e. the proportions of direct and diffuse radiation). Existing approaches used in interception models for forest and orchard canopies have been recently extended to olive. Mariscal et al. (2000a) have developed a model of the interception of photosynthetically active radiation (PAR) and its distribution within the canopies of olive orchards. The geometrical analysis has separate treatments of the passage of direct and diffuse radiation through tree canopies of defined tree spacing, row orientation, canopy height, canopy volume, leaf area density, leaf angle distributions, and leaf optical properties. The model is appropriate for the calculation of tree or orchard photosynthesis and could also be useful in the analysis of flower survival, fruit survival, fruit filling, and fruit color. On the other hand, for many practical applications, interception is readily measured with linear PAR sensors and, in this, olive orchards have the advantage that canopy structure does not change rapidly.

\section{Tree and Canopy Photosynthesis}

There are no published data on direct measurement of photosynthesis of olive trees or orchard canopies. Information is required not just on total canopy photosynthesis but also on the distribution of activity throughout the canopy. The latter should contribute significantly to understanding flowering, fruit set and fruit filling, as well as devising 
improved strategies and timings of pruning. The lack of such measurements is a major restriction to the development of models of olive productivity. Current attempts at modelling (see Section VIII) have been developed using net growth in response to intercepted radiation (RUE). This approach avoids the issue of assimilate balance (photosynthesis and respiration separately) that is central to understanding source-sink activities in the partitioning of biomass - an important part of growth strategy and adaptation of the perennial olive.

With the data available at present, it is only possible to make rough estimates of orchard photosynthesis, in the absence of stress, using quantum efficiency $(\varphi)$ as introduced in Section VA. If one assumes, for example, that the average conversion efficiency of intercepted radiation is one half of $\varphi$ to account for reflection and the relatively high irradiance received by many leaves in the canopy, then the product of PAR $\times$ effective crop cover $\times \varphi / 2$ will estimate orchard photosynthesis. Thus for an orchard of full cover $(\mathrm{CC}=1)$, daily gross photosynthesis with incoming short wave radiation of $20 \mathrm{MJ} \mathrm{m}^{-2}$ would be $20 \mathrm{MJ} \mathrm{m}^{-2} \times 2.06\left(\mathrm{~mol}\right.$ quanta $\left.\mathrm{MJ}^{-1}\right) \times 0.026 / 2\left(\mathrm{~mol} \mathrm{CO}_{2}\right.$ mol quanta $\left.{ }^{-1}\right)=0.54 \mathrm{~mol} \mathrm{CO}_{2} \mathrm{~m}^{-2}$, corresponding, with a respiratory loss of $30 \%$, to a net photosynthetic gain of $16.6 \mathrm{~g} \mathrm{CO}_{2} \mathrm{~m}^{-2}$. This, converted to estimate biomass gain of ca. $13.1 \mathrm{~g} \mathrm{~m}^{-2}$, including an ash content of $8 \%$, would estimate radiation-use efficiency (RUE) of $1.31 \mathrm{~g} \mathrm{MJ}^{-1}$ (PAR) comparable with the value of 1.35 that Mariscal et al. (2000b) measured experimentally.

\section{BIOMASS PARTITIONING AND DEVELOPMENT OF YIELD}

Plant organs, roots, stems, leaves, and fruits, can be considered as a group of connected sources and sinks, whose seasonal patterns of supply and demand determine the partitioning of assimilates among them, and hence the survival, growth, and yield of the entire plant. A simple view sees leaves as the major source of assimilates and all other organs are sinks, but a more complex description of plant assimilate relationships is required because many organs can serve as both sources and sinks. Sink strength is determined by size and by two components of activity. First, assimilate to support general metabolism (MR) and second, for growth of existing and new organs (CR). The development of new organs, leaf and shoot units, flowers, roots, and fruits, that appear in response to external and internal signals are of particular importance here. The flow of assimilates from sources to sinks is determined by proximity and anatomical connectedness. In the event of inadequate supply for all maintenance and growth activities, sinks will compete for assimilate, with variable effects on plant production and survival.

The supply and demand for assimilates in plants also responds to plant hormones, and in this, $\mathrm{N}$ plays an important role. Roots export $\mathrm{NO}_{3}{ }^{-}$to leaves where it is reduced to the amino level at substantial energetic cost. This growth strategy reduces the energy cost of root systems that receive metabolites by return flow through the phloem. It is known, in many plants, that when $\mathrm{NO}_{3}{ }^{-}$levels are high roots also export cytokinins, plant hormones that stimulate cell division and growth. Alternatively, when $\mathrm{NO}_{3}{ }^{-}$levels are low, xylem sap is more concentrated in abscisic acids, hormones that restrict cell division, cause stomatal closure (Zhang and Davis 1990; Peuke et al. 1994), and increase leaf abscission in olive cuttings (Kitsaki et al. 1999). Because $\mathrm{NO}_{3}{ }^{-}$moves in the transpiration stream, its quantity and composition signal the shoot of both water supply 
and fertility available from roots. Herein lays the theory behind partial root zone drying (PRD) that is being applied with variable success to vines (Dry and Loveys 1999; Dry et al. 2000), but has not, as yet, been evaluated in olive. By alternating irrigation on opposite sides of the root zone, the notion is to develop root signals to close stomata, control growth, and reduce overall water demand, without exposing the plant to severe water stress. In practice, the ability to achieve alternate wetting and drying depends upon rainfall patterns and importantly soil water-holding capacity, being more effective in soils of light texture. It now appears, however, that irrigation water deficits imposed in this fashion, have the same effects on growth, water relations and productivity as those produced when the same quantity of water is applied with conventional deficit irrigation practices (Fereres et al. 2003). The advantage of double irrigation lines may reside in a larger wetted zone and a more extensive root system that may be of value in arid areas with marginal soils (see Section IIIA).

Two questions arise from the above description of assimilate relationships within plants. First, how much of this behavior is known for olive. Second, does current knowledge support the validity of this source-sink approach to its assimilate relationships and growth. There is little information to answer the first question, so the second question cannot be answered. The only structured study is that of Priestley (1977) who studied the monthly growth and assimilate profiles in leaves, stems, and roots of 3-yearold potted plants of 'Ascolana' for one yearly cycle. That study demonstrated aspects of the coordination of growth and also that chemical techniques are available to distinguish the assimilate content of organs from their biomass (Proietti et al. 1999b). Growth was most rapid in summer and took place in all organs concurrently. There were no signs of alternating growth among organs. The data also describe the seasonal variability of assimilate in the various organs, showing, for example, the importance of leaves in storing as well as producing assimilate. Even in these young plants, total non-structural carbohydrates accounted for $50 \%$ of dry weight in mature leaves compared with $40 \%$ in stems and $10 \%$ in roots.

A paucity of information on assimilate relationships is not unusual, even to wellstudied annual crops. In the case of olive, we have much information on assimilation by individual leaves and on the productivity of olive fruit (mass and oil), but little else. There are even few static descriptions of the distribution of biomass between organs, let alone on the factors that control partitioning of assimilates among organs. There is evidence of competition for assimilates during flowering and fruit growth (Rallo and Suarez 1989), and the same probably applies to more general interactions between canopy, trunk, and root system.

\section{A. Movement of Assimilate from Leaves.}

Measurements of phloem exudates reveal that assimilates are translocated from olive leaves mainly as raffinose oligosaccharides (50\%, predominantly stachyose) and sucrose (30\%), with mannitol comprising a small proportion $(<10 \%)$ (Flora and Matore 1993; Gucci et al. 1998b). This contrasts with the sugar composition of leaf tissue in which mannitol forms the major component (30\%), followed by glucose $(18 \%)$, sucrose $(8 \%)$, and various oligosaccharide precursors (galactose, raffinose, verbascose). Pulse chase experiments with $\mathrm{C}^{14}$ reveal the location and sequence of the interconversions. Mannitol and sucrose are formed rapidly ( $2 \mathrm{~min}$ ) from the primary assimilate, glucose, in the 
mesophyll close to site of $\mathrm{C}$ fixation. Mannitol is synthesized in the cytosol from mannose-6-P and quickly localized in cell vacuoles. In contrast, stachyose (sucrose+galactose+galactose) and raffinose (sucrose+galactose) appear later (10 min), consistent with synthesis closer to the point of phloem loading, probably in the intermediary cells associated with minor vein endings (Flora and Matore 1993). This transport-synthesis sequence for the major translocates may explain why Gucci and Minchin (2002) reported slow translocation of $\mathrm{C}^{11}$ label in their observations of in situ translocation from olive leaves. Mannitol has been shown to increase in concentration in leaves of plants subjected to salinity stress as well as water stress (Gucci et al. 1998a; Gucci et al. 1998b), but the role of mannitol as an intermediate store of assimilate and the adaptive significance, if any, of the dominance of assimilate transport as stachyose in olive remain unclear.

Other important aspects of assimilate relations relate to linkages between organs. There is some information on this from labelling and defoliation experiments. Studies of the movement of isotopically labelled $\left(\mathrm{C}^{11}\right)$ assimilate from leaves along an actively growing olive shoot, cultivar unspecified (Gucci and Minchin 2002), revealed that assimilate movement depended on leaf age. In this case there was no export within $2 \mathrm{hr}$ from the youngest expanded leaf but assimilate flowed in both directions; the older the leaf position, the more assimilate moved out of the stem. This pattern has been seen in many plants. Other important features, not shown here, and so far not confirmed for olive, are that young expanding leaves may be importers and exporters at the same time, and that once expanded, old leaves do not become importers, even when they enter a period of negative carbon balance due to shading or senescence. In defoliation and shading experiments, Proietti and Tombesi (1996) have further inferred the effective isolation of branches, to the tertiary level, in terms of vegetative growth, and limited transfer from closely associated branches for fruit growth. Sub-units of the tree canopy act more or less independently to support their own growth, including that of fruit, while maintaining active xylem and phloem connections with the root system via the subtending stems and branches. A tree may then be considered, from the standpoint of carbon utilization, as a collection of branches loosely connected and operating individually. The implications of this notion to attempts to extrapolate measurements at the leaf level up to the canopy are obvious. Virtually nothing is known of the long distance relationships that determine the contribution of assimilate to trunks and roots.

\section{B. Above- and Below-ground Biomass}

Growth and partitioning of biomass were studied during the first two years of two fully irrigated high-density 'Picual' orchards, 5000 and 20,000 trees ha ${ }^{-1}$, at Córdoba (Mariscal et al. 2000b). There was a large response of total growth to tree density. Competition among trees was evident in summer of the second year (from day 500) as divergences in stem diameter and plant leaf area between the two densities. There was, however, a strong linear relationship between the biomass of the organs in all cases. The young olive trees partitioned 0.26 of total biomass to roots and of the remainder $(0.74)$ that remained in shoots, $60 \%$ was in wood and $40 \%$ in leaves. As competition increased in the second year, biomass partitioned to wood (trunk, branches, and stems) increased to $70 \%$. Other data on root-shoot partitioning of olive orchards provide comparable data and also describe the impact of water shortage on partitioning. Dichio et al. (2002) reported 
measurements on 'Coratina' for 8 years after planting at $6 \times 6 \mathrm{~m}$ spacing. Up to year 5 , shoots retained a steady proportion of total biomass, 0.76 and 0.69 for irrigated and rainfed treatments, respectively. Towards year 8, partitioning to roots increased, so that shoots then represented a smaller proportion, 0.58 and 0.55 , of total biomass. Water shortage reduced overall growth, 33 vs. $19 \mathrm{t} \mathrm{ha}^{-1}$ for irrigated and rain-fed treatments, respectively, but the effect was seen more in the stem and canopy than in the root system. This response is common to most plants and is an advantageous adaptation that establishes a more favorable water balance under drought conditions.

An important issue in considerations of the partition of biomass between organs concerns the energetic cost of dry matter production that was seen earlier (Section V) in the explanation of the glucose requirement (GR) for growth. Leaves, stems and fruits of olive have markedly different chemical constitution and therefore have different assimilate costs of production. In their study of biomass production and partition in young orchards of 'Picual', Mariscal et al. (2000b) estimated GR $=1.49$ ( cf. 1.66 by Merino 1987), 1.43, and 1.54 for leaves, fine branches and trunk respectively. The value for fruit varies depending upon composition, especially oil content for which GR = 3.11. For oil cultivars, GR of fruit is 2.3 , for an estimated composition of oil $=50 \%$, sugar $=$ $10 \%$, lignin $=27 \%$, protein $=9 \%$, and minerals $=2 \%$ (Hermoso et al. 1998; Jordão and Lietão 1990).

\section{Shoots and Fruit}

The seasonal distribution of biomass within a fruit-bearing limb ("on" year) of 8-year-old trees of 'Picual', studied by Rallo and Suarez (1989), displayed the growth and interactions of the component organs. The presence of fruit greatly reduced concurrent vegetative growth relative to the "off" condition, by 50 and $40 \%$ for new nodes and new leaf area, respectively. The major proportion of new biomass was directed to the fruit. Accounting for a 50\% reduction in the biomass of previous year's leaves, $85 \%$ of new biomass from PS65 to PS79 was in fruit, with the rest in new leaves (10\%) and shoots $(5 \%)$. The previously existing shoot did not increase in biomass. Those data reflect an even greater diversion of current assimilate to fruit.

Competition between shoot and fruit during "on" years is also an important determinant of yield in the following year, because shoot growth provides the sites for flower formation. The role of assimilate supply for floral induction, a process that occurs during fruit growth, is uncertain. Both leaves and fruit are involved in the internal signals that influence the process, but the distinction between assimilate supply and other exports from leaves has not been satisfactorily resolved. The experiments of Proietti and Tombesi (1996), for example, revealed a dramatic effect of defoliation and intense shading on return to flowering as well as on current fruit growth. Given the relative isolation of shoots with regard to assimilate (Proietti and Tombesi 1996), however, it seems highly likely that the treatments imposed on assimilate supply were too severe for a proper conclusion.

The irregular distribution of fruit in the canopy and its importance to tree productivity and management have long been recognized (Ortega Nieto 1945). Fruit are formed preferentially on the more-illuminated parts of canopies, the top and southern sides in the northern hemisphere. Pruning practice, well illustrated in the widely used 
open-vase form, is directed to improve light penetration to promote more fruiting sites. Surprisingly, though, there has been little research on the role of assimilate in the sequential steps from floral initiation to fruit filling.

Acebedo et al. (2002) studied flower and fruit dynamics in $6 \times 6 \mathrm{~m}, 16$-year-old ca. N-S planted orchards, of two widely planted cultivars at Mengibar, Spain. 'Picual' forms a relatively open canopy and usually sets one large fruit per inflorescence, while 'Arbequina' is shrubby, more dense, and sets small, multiple fruit. The authors followed the fate of flowers on previous year's shoots formed at five positions around the periphery (top, N, S, E, W at $1.5 \mathrm{~m}$ height), low (L) on the south side at $0.4 \mathrm{~m}$, and within the canopy (I) adjacent to it. They established differences in behavior between locations that became increasingly pronounced in the sequence, inflorescence number, fruit number, and fruit weight per shoot (Fig. 5). Both cultivars showed the dominance of top and exposed locations in fruit yield and oil percentage. The major difference between cultivars was in fruit number, which did not translate into more fruit weight per shoot. This sequence suggests the increasing importance of assimilate supply on fruit filling and oil content. It should now be possible to combine measurements of orchard illumination patterns and models of canopy photosynthesis to the study of this issue, and importantly, extend the analysis to new orchard designs distinct from those developed by traditional practice over centuries.

\section{Assimilate Supply and Oil Formation.}

There are two sources, relative sizes unknown (and probably variable), of assimilate for fruit growth in olive. The major source is certainly the sugars translocated in the phloem from leaves or sites of storage. These were seen previously to comprise raffinose oligosaccharides (mainly stachyose) and sucrose. The secondary source is sugars formed by photosynthesis in fruit themselves that remain green for a considerable period and retain active chlorophyll even when they change color (PS81) as they approach maturity. While chlorophyll is mostly in the exocarp, the mesocarp has been shown to contain significant amounts of phosphoenol pyruvate carboxylase (Sánchez 1994), the $\mathrm{CO}_{2}$ fixation enzyme of the CAM and $\mathrm{C}_{4}$ photosynthetic pathways. This means that fruit can continuously sequester respiratory $\mathrm{CO}_{2}$ in the mesocarp and release it to enter the Calvin Cycle $\left(\mathrm{C}_{3}\right)$ photosynthesis during the light, along with any free $\mathrm{CO}_{2}$ in the tissue at that time. This internal $\mathrm{CO}_{2}$ is generated by the intense metabolism related, initially with the cell division and growth, and later, and for a considerable period, to the synthesis of oil. On this point, it seems that seed and mesocarp behave differently with respect to assimilate supply. Seed growth depends exclusively on assimilate imported by the phloem while isotopic label was recovered only from the mesocarp when photosynthesizing fruit were exposed to $\mathrm{C}^{14} \mathrm{O}_{2}$ at 21 weeks after full bloom (Sánchez 1994).

Observations confirm that fruit photosynthesis makes a positive contribution to mesocarp growth, even though the $\mathrm{CO}_{2}$ balance of fruit is apparently negative from the outset. Comparisons of $\mathrm{CO}_{2}$ exchange in light and dark (Proietti et al. 1999a) reveal that young fruit in full sunlight are able to fix up to $80 \%$ of respired $\mathrm{CO}_{2}$, the proportion falling gradually to zero towards maturity as chlorophyll is lost. The provision of $\mathrm{CO}_{2}$ for photosynthesis was considerable, with internal $\mathrm{C}_{\mathrm{i}}$ always $>400 \mu \mathrm{mol} \mathrm{mol}{ }^{-1}$ and rising to $800 \mu \mathrm{mol} \mathrm{mol}{ }^{-1}$ during the second half of the fruit-filling period when the conductance of 
the exocarp fell as stomata were lost and cuticular wax thickened. The available $\mathrm{CO}_{2}$ balance data do not, however, allow an estimate of the overall contribution that refixation makes to mesocarp growth over the seasonal cycle. If re-fixation reduces the dependence of fruit growth on current assimilation rate to a significant extent, that may help explain why fruit load had no apparent effect on leaf photosynthetic rate (Proietti 2000), a source-sink feedback that has been observed in many crop plants.

The sugar content of young mesocarp is high, around $20 \%$ dry matter, but falls steadily as the mesocarp accumulates oil. The synthesis and formation of these storage lipids (triacylglycerols, TAG) is complex requiring many steps, essentially common to all plants (Browse and Somerville 1991), that occur in various cellular compartments. Aerobic respiration of sugars provides acetyl CoA and malonyl CoA the primer and building blocks, respectively, for the stepwise elongation of the fatty acid chain. This process involves a multi-enzyme fatty acid synthase (FAS) complex and a low molecular weight acyl-carrier protein that sequentially adds $2-\mathrm{C}$ units up to the saturated 16-C stage (C16:0, palmitic). Further elongation with some desaturation, not controlled by FAS, continues with the majority terminating at the $18-\mathrm{C}$ stage in olive. The storage triacylglycerols (TAG) are then formed by sequential acylation of glycerol-3-phosphate and desaturation steps that determine the fatty acid profile of the fruit (and cultivar). Oil bodies are formed by accumulation of TAG within leaflets of the endoplasmic reticulum.

Oil formation commences around pit hardening (PS75), about 2 months after full bloom (PS65), and persists for 100+ days. The oil concentration in the seed increases quickly and reaches a maximum well before ripening begins (PS81) but continues in the mesocarp even after this time. The pattern of accumulation varies greatly, including between oil cultivars. Garcia and Mancha (1992) presented a comparison of lipid synthesis capabilities of 'Picual' and 'Gordal', measured by the incorporation of ${ }^{14} \mathrm{C}$ labelled acetate in slices of mesocarp tissue. The activity in 'Picual', an oil cultivar, was three times greater, peaked later, and persisted longer than in 'Gordal', a table cultivar. A comparison of oil accumulation in the six cultivars, 'Carolea', 'Maurino', 'Leccino', 'Frantoio', 'Moraiolo' and 'Dolce Agogia', was presented by Farinelli et al. (2002) (Table 3, Fig. 6). Oil formation commenced first in 'Carolea' (41 days after full bloom) with the other cultivars following about 20 days later. 'Leccino' and 'Moraiolo' had the longest oil-filling period of 172 days but the seasonal patterns varied considerably. 'Carolea' had the greatest relative rate of $21.5 \mathrm{mg}$ oil (g fruit) ${ }^{-1}$ day $^{-1}$ and 'Maurino' and 'Moraiolo' the least at $9.5 \mathrm{mg}$ oil ( $\mathrm{g}$ fruit) ${ }^{-1}$ day $^{-1}$. Compared to the variability in these production patterns, the data also reveal relative consistency in oil content and composition among cultivars, compared with the variability of polyphenol content, as discussed above.

Hermoso et al. (1998) provide a general description of the composition of oil cultivars. Total fruit weight, comprises 70 to $90 \%$ mesocarp, 9 to $27 \%$ endocarp, and 2 to $3 \%$ seed. At the usual harvest time for oil production, mesocarp has about $60 \%$ water, $30 \%$ oil, $4 \%$ sugars, $3 \%$ protein, and the rest primarily fibre and ash. The endocarp has $10 \%$ water, $30 \%$ cellulose, $40 \%$ other carbohydrates, and about $1 \%$ oil. The seed has $30 \%$ water, $27 \%$ oil, $27 \%$ carbohydrates, and $10 \%$ protein.

Two features endow a human dietary advantage to olive oil. First, the monounsaturated oleic acid (C18:1) which exists in high proportions, up to $80 \%$, has strong 
hypocholesterolemic properties and is considered to reduce the risk of coronary diseases. Other acids, present in smaller amounts, are the saturated palmitic (C16:0, 10 to 15\%) and stearic (C18:0, 2 to $3 \%)$, and the polyunsaturated linoleic (C18:2, 5 to $10 \%)$ (Tombesi 1994). Linoleic acid also has hypocholesterolemic properties and is as an essential fatty acid, i.e. is required but is not synthesized by human metabolism. Second, a range of antioxidant phenolic compounds, especially in virgin oil, are active in reducing the incidence of bowel and breast cancer (Owen et al. 2000; Visioli et al. 2002). Other constituents important in the market place are flavor (organoleptic) compounds that are produced enzymatically in the mesocarp and transferred to the oil during extraction by pressing. The types and amounts of oils and organoleptics have a strong genetic base and are, therefore, characteristic of individual cultivars, but are also under environmental control. Uceda and Hermoso (1998) report a comparison of oil and organoleptic properties of 30 cultivars, harvested over five years. Cultivar explained 78, 71 and $46 \%$ of the variation in the contents of oleic acid, tocopherols, and polyphenols, respectively.

\section{STRESS PHYSIOLOGY}

The ability of olive to survive and yield in marginal areas is based on resistance to environmental stresses of drought, low temperature, and salinity. Water stress is common in Mediterranean environments and olive has long been considered a tree adapted "par excellence" to water deficit. The importance of low temperature has increased as production has moved to higher latitudes and higher altitudes within the present zone of distribution. Salinity is a common problem in soils of arid and coastal environments and is becoming more important in olive production as the search to increase productivity by irrigation is challenged by water of low quality.

Resistance to stress is usefully considered with components of escape, avoidance, and tolerance (Loomis and Connor 1992). The first, escape, derives from development patterns that allow plants to complete life cycles without stress in potentially stressful environments. In contrast, avoidance and tolerance, derive from physiological attributes. Avoidance mechanisms maintain high internal water or low salt in the face of stress, when these mechanisms fail or are insufficient, stress resistance depends upon tolerance to adverse internal conditions.

From a strategic viewpoint, it is interesting to compare the success of olive with that of winter cereals, the major productive option for rain fed agriculture in the Mediterranean environment. For these annual cereals, success in this environment is primarily achieved by rapid phenological development (drought escape) combined with aspects of drought avoidance (Loomis and Connor 1991). For perennial, evergreen olive, in contrast, success depends upon a broad combination of avoidance and tolerance attributes.

\section{A. Drought}

Olive culture has prospered under rain fed conditions in Mediterranean environments because the tree is capable of acceptable yield while subjected to the characteristic prolonged summer water shortage (drought). Olive achieves this result with physiological and morphological responses that reduce water loss and maintain water uptake at high plant water status as drought commences (drought avoidance), with others that maintain turgor and tolerate dehydration at low plant water status as the drought 
deepens (drought tolerance). In general terms, drought avoidance combines low leaf conductance, low leaf area, minimizing radiation load, deep roots, high root length density, and high hydraulic conductance. Olive maintains turgor by osmotic adjustment of cell contents, small cell size, and changes in cell wall elasticity. Olive also tolerates dehydration by other properties of protoplasm and cell wall. For productivity, rain fed olive must tolerate summer drought and recover quickly to fill fruit in Autumn. The success of this strategy is aided by conservative water use in Spring that in turn minimizes the extent and intensity of the ensuing summer drought.

1. Leaf Water Relations. Olive leaf tissue has the ability to tolerate and recover from low $\psi_{1}$ ( <-8 MPa) (Xiloyannis et al. 1988; Moriana et al. 2003) that would kill most annual and perennial crop plants. Olive leaves reduce radiation load by adopting a more vertical angle (Natali et al. 1999) and also maintain turgor and functionality at low $\psi_{1}$ by osmotic adjustment. The latter response is further aided under dehydration by high tissue elasticity (Bosabalidis and Kofidis 2002). A study of the relation between relative water content and $\psi_{1}$ (moisture release curves) of leaf tissue of 'Picual' (E. Fereres, unpublished) revealed significant osmotic adjustment (ca. $1 \mathrm{MPa}$ ) when soil water deficit lowered predawn $\psi_{1}$ from -1 to $-4 \mathrm{MPa}$. These moisture release curves exhibited a large change in $\psi_{1}$ per unit hydration change, indicative of relatively rigid cell walls which confer the advantage of sustaining low $\psi_{1}$ with moderate dehydration (Kramer and Boyer 1995). The combination of the capacity of olive to lower $\psi_{1}$ below $-8 \mathrm{MPa}$ and an extensive root system enhances capacity to withstand drought by increasing the volume of extractable soil water. Moriana et al. (2003) estimated that rain fed trees with $\psi_{1}$ around $-8 \mathrm{MPa}$ extracted an additional $40 \mathrm{~mm}$ from below the conventional permanent wilting point of $-1.5 \mathrm{MPa}$ in a $240-\mathrm{cm}$ deep profile. This is a significant additional contribution that corresponds to 10 to $15 \%$ of the seasonal ET of a traditional rain fed orchard in that area (Orgaz and Fereres 1998).

The diurnal pattern of leaf conductance and photosynthesis of olive follows, contrary to that observed in most crop plants, the optimization theory of stomatal operation in relation to water use proposed by (Cowan 1982). When the tree is subjected to water deficit, this behavior becomes even more firmly established. Transpiration efficiency (TE) is maximized, as stress develops, because stomata open (greatest diurnal $\mathrm{g}_{1}$ ) earlier each day, when VPD is lowest, and remain open for shorter periods.

Transpiration efficiency was four times greater in the early morning than at midday (Moriana et al. 2002). While it is well established that severe water stress decreases TE in many plants due to direct effects on the photosynthetic apparatus (Brodribb 1996), the response of olive is uncertain. For example, there was no effect of water stress on TE of severely stressed olive until $\psi_{1}$ fell below $-4.4 \mathrm{MPa}$ (Moriana et al. 2002) and Larcher et al. (1981) found that TE increased (relative to control) in potted olive trees when rehydrated following cycles of water stress. Comparable behavior, that would hold great adaptive significance, has not been established in the field although TE, that had decreased under severe water deficit, returned to normal values immediately after the first autumn rain (Moriana et al. 2002).

Taken together, these observations on stomatal response point to efficient capture of carbon by olive leaves at low water cost, even when trees are subjected to substantial water deficit. It remains to be seen if these leaf-level responses to stress translate to 
favorable responses to water deficit at tree and orchard levels. If such observations confirm the curvilinear relationship found between yield and ET in olive ( Patumi et al. 2002; Moriana et al. 2003) that defines greater water productivity below maximum ET, they would lend theoretical support to the value of deficit irrigation in this crop, a practice already used extensively in areas of limited water supply.

2. Xylem Cavitation and Vulnerability to Embolisms. Water is transported in the xylem under tension and is therefore vulnerable under drought (low $\left.\psi_{1}\right)$ to cavitation and the rapid expansion of a gas-filled space (embolism) within individual xylem conduits. Cavitation may be initiated during water stress by the entry of air through conduit pit membranes when xylem tension exceeds a critical level, or by bubbles formed during freezing and thawing of xylem sap. Cavitation has been demonstrated in water-stressed plants by acoustic techniques (Milburn and Johnson 1966; Tyree and Sperry 1989) and measured by changes in hydraulic conductivity of excised stem or root sections before and after pressurization with degassed water to remove embolisms (Sperry et al. 1988; Tyree et al. 1995; Lo Gullo et al. 1998).

Embolisms are important because they reduce the hydraulic conductivity of the xylem giving rise to the possibility of 'runaway' reduction in hydraulic conductance unless transpiration is reduced to relieve tension and prevent further cavitation (Tyree and Ewers 1991). Stems harvested from trees usually have a degree of embolism and Tyree and Sperry (1988) have estimated an ability to accommodate a 5 to $20 \%$ loss of hydraulic conductance without danger of approaching an unstable state. Adaptations to minimize the number of cavitations are found in the small diameter of conduits and the ability of pit membranes to prevent expansion of embolisms into neighboring conduits. Adaptations to minimize the effect of embolisms on xylem hydraulic conductivity are found in short conduits and the generally complex pathway of water flow (Sperry 2003). Optimization of xylem structure thus requires a balanced adaptation because the features that reduce vulnerability to cavitation, narrow conduits and many inter-conduit connections, also result in the low hydraulic conductivity that generates the high xylem tensions that trigger cavitation. Of particular importance here is the fourth power relationship (Poiseulle's Law) between conduit diameter and hydraulic conductance. To maintain equivalent xylem hydraulic conductivity, the aggregate area of vessel conduits must increase dramatically as the diameter of individual conduits decreases.

Until recently, embolisms were thought to be largely irreversible (Sperry 1995) and thus cavitation was considered a serious xylem dysfunction in plants, whose repair in woody species must then generally await the formation of new water-filled xylem vessels around the expanding periphery. That process is undoubtedly important but it now appears that embolisms can be repaired (Salleo et al. 1996; Hacke and Sperry 2003) and that xylem hydraulic conductance may consequently vary from day to day, or even diurnally. There is also the suggestion that the hydraulic shock from individual embolisms may play a role in regulating stomatal conductance (Salleo et al. 2000) and that the release of water may contribute significantly to the capacitance of the xylem tissue (Meinzer et al. 2001).

Some of this work on drought response and adaptation has been undertaken on sclerophylls of the Mediterranean region (Lo Gullo et al. 1998; Martínez-Vilalta et al. 2002). Lo Gullo et al. (1998) measured the response of root hydraulic conductivity of 
potted seedlings of wild olive $(O$. oleaster) to water stress and subsequent watering. They recorded significant decreases in hydraulic conductivity that were only recoverable following short, mild stress. Observations on root anatomy revealed loss of roots and also changes to root anatomy. A thicker, more suberized endodermis decreased conductivity from soil into the stele, the least conductive part of the transport pathway in the root. Given these morphological and anatomical changes, complete recovery of root conductivity was achieved only following the growth of new roots. A study of the hydraulic properties and vulnerability to cavitation of nine woody species of an evergreen oak forest in Catalonia, Spain, included Phillyrea latifoli (Oleaceae) (Martínez-Vilalta et al. 2002). It established a common trade-off across species and their component tissues between hydraulic conductivity and xylem security. The latter, expressing the resistance to cavitation, was parameterized as the water potential causing a $50 \%$ decrease in hydraulic conductivity per unit conducting area (specific conductivity). Xylem security increased with decreasing conduit diameter (d) according to relationship $1 / \mathrm{d}^{2}$. According to this criterion, roots of the studied species operated closer to their hydraulic limit for cavitation than did stems. This characteristic has also been reported for other species and potentially holds important clues for evolution of xylem tissues, ecological adaptation of species, and the mechanisms by which embolisms can be repaired. As yet, there have been neither observations nor analyses on cavitation responses in olive. This could now be a priority area for research, given the low water potentials that the tree sustains and the unanswered questions concerning stomatal responses.

3. Flowering and Fruit Filling. Compared to the water relations of leaves of droughted plants, there is relatively little information on the drought responses of the reproductive processes from flowering through fruit growth to oil accumulation.

Olive flowers late compared with winter cereals adapted to the Mediterranean climate. This late-Spring flowering behavior is consistent with the subtropical origin of the plant (Section II) and presents a compromise between the risk of damage by cold and by water deficit. While it significantly decreases the risk of flowering to low temperature, it increases the risk of damage to flowering by water and/or high temperature stress, and also delays fruit growth into an extended period of water shortage. There exists a wide range of flowering responses (Barranco et al. 1994), as yet incompletely understood (Section IIC), that is the basis for adaptation of cultivars to individual sites.

Observations in drought years suggest the possible loss of most flowers or fruits when water deficits develop, a response that enhances the alternate bearing habit. Thus, while there is very little doubt that flowering and fruit set are very sensitive to water deficits (Moriana et al. 2003), there is an urgent need for studies to uncover the degree of sensitivity, the potential for adaptation to stress, and the possibility of differential responses among cultivars, especially as olive cultivation extends into drier environments.

The nature and pattern of fruit growth is important to adaptation to drought and also to the effectiveness of various irrigation strategies. Olive does not follow the classical pattern of cell division and expansion described for drupes (Bollard 1970). Recent work has shown that cell division and cell expansion are both active in the mesocarp at 8 to 10 weeks after full bloom when expansion of the endocarp is virtually 
complete (PS75) (Rallo and Rapoport 2001). From then until maturity, considerable cell expansion occurs and up to $40 \%$ of mesocarp cells may be produced, depending on cultivar (Manrique et al. 1999). The timing as well as the extent of stress, therefore, determine the effect on cell number and cell size. Rapoport et al. (2004) studied the effect of water shortage during the first 4 to 9 weeks after full bloom (PS65) on fruit growth of 3-year-old potted plants of 'Leccino'. Predawn $\psi_{1}$ fell to $-3.1 \mathrm{MPa}$ in the stress treatment compared to $-0.8 \mathrm{MPa}$ in the control. Measurements taken at 6,8 , and 22 weeks after full bloom were taken to assess the impact of water stress and recovery of fruit characteristics. Mesocarp cell size (area) was reduced to $40 \%$ of the control by the end of the stress period (week 8) and recovered to $65 \%$ by week 22 . In contrast, mesocarp cell number was unaffected during the treatment period and division continued comparable with the control during recovery when ca. $15 \%$ of final cell number was produced. The major effect of drought was seen in the endocarp. By the end of the stress period (week 8), it had achieved $90 \%$ of final growth in the control but only $40 \%$ under stress. Thus by week 8 , fruit fresh weight (1.13 v. $2.25 \mathrm{~g})$ and volume (1.6 v. 2.6 cc) were substantially reduced compared to the control, and recovery remained incomplete to week 22 (PS81). At that time, the dry weight and oil contents of the mesocarp were unaffected by the early stress (mean values 25 and $46 \%$ ). In general, the reported effects in the literature of drought and irrigation practice on oil proportion and quality have been variable (see Patumi et al. 2002) and this not surprising considering the range of cultivar, stress level, timing, and duration involved as well as the range of parameters needed to define oil quality.

Olive growers commonly express surprise at the capacity of the tree to recover from prolonged summer drought to produce reasonable yields. It is likely that the ability of olive to recover from water deficit is its most important feature of drought response. Thus, in a 1983 experiment at Cordoba (E. Fereres unpublished), trees of 'Picual' rehydrated within three days from a predawn $\psi_{1}$ of $-4 \mathrm{MPa}$ to reach normal $\mathrm{g}_{1}$ in less than two weeks. Further observations at Cordoba in 1995 when an unusual drought lowered $\psi_{1}$ to $-8.0 \mathrm{MPa}$ in some trees are summarized in Fig. 7. Despite the initial low $\psi_{1}$, trees reached control values and were fully re-hydrated within six days of $60 \mathrm{~mm}$ of rain received over two days in early November (Fig. 7a). The recovery of $g_{1}$ was much slower, as seen in many species (Hsiao 1973). Leaf conductance increased after the rain but remained below control values for about two weeks. Interestingly, there was much tree-to-tree variation in $\mathrm{g}_{1}$ and those trees that had a heavy fruit load, also had high $\mathrm{g}_{1}$, in some cases as high as in control trees (Fig. 7b). It appears that functional recovery, and presumably carbon assimilation, was faster in trees with a heavy fruit load, leading to a recovery in fruit growth and yield. Moriana et al. (2003), showed that oil accumulation is slowed or perhaps stopped by summer drought, but resumes in the stressed treatments in Autumn at a faster rate than in fully irrigated trees.

\section{B. Low Temperature}

Olive has good cold tolerance compared to other species that share its subtropical origins (Larcher 1987). Leaves and bark can withstand temperatures to $-12^{\circ} \mathrm{C}$ or less, depending upon cultivar and duration, provided the tissues have been previously hardened by prolonged exposure to temperature in the range 0 to $5^{\circ} \mathrm{C}$ (Bartolozzi and Fontanazza 1999). Significant damage to aerial parts, mainly leaf drop and twig desiccation, that 
threaten survival and reduce productivity can, however, be expected at temperatures around $-7^{\circ} \mathrm{C}$ (Palliotti and Bongi 1996). In susceptible areas, damage is greatest in late autumn and early winter, decreasing in severity for the same temperatures as the plants gradually harden. Young plants require hardening before planting in the field because they are especially susceptible to low temperature. In newly planted orchards, sensitive leaf and apex tissues are close to the ground where temperature is lowest during radiative frosts. In contrast to the substantial tolerance of bark and leaves, the reproductive organs, flower buds and flowers, are seriously damaged by temperatures around $0^{\circ} \mathrm{C}$ and there is

Field experience, for example after the 1985 and 1991 freezes in Italy (Roselli et al. 1989; Bartolozzi and Fontanazza 1999) and in experiments with young trees in controlled environments (Mancuso 1998, 2000), have enabled the classification of some cultivars with regard to cold tolerance (Table 4). The wide range of olive germplasm means, however, that evaluation is far from complete so further understanding of response mechanisms to freezing temperatures is required to improve selection for cold tolerance.

Studies with many plant species have shown that damage to tissues becomes irreversible when ice forms and disrupts membranes and organelles. Further, it is known that tolerance to deep cold depends upon the ability of tissue to supercool through metabolic adjustments that lower freezing point. Measurement of supercooling and tissue damage now form the basis of tests designed to compare the behavior of cultivars. The challenge remains to ensure that such tests correlate well with field performance. Alternative screening techniques rely on correlations. For example Roselli et al. (1989) have reported that low stomatal density correlated well with cold hardiness in cultivars that experienced the severe freeze $\left(<-20^{\circ} \mathrm{C}\right)$ in Tuscany in 1985.

Measurements of freezing tolerance on leaves are made by sampling stem segments to detect ionic leakage (leaf discs give unstable results), and on bark and leaves by measurements of differential thermal analysis and of electrical conductivity during cooling (Bartolozzi and Fontanazza 1999; Mancuso 2000). Ion leakage identifies that freezing has occurred while differential thermal analysis and electrical conductivity identify membrane disruption. Mancuso (2000) showed that measurements of freezing temperature made by electrical conductivity satisfactorily discriminated between two cold-tolerant, 'Ascolana' $\left(-14.5^{\circ} \mathrm{C}\right)$, 'Leccino' $\left(-12.9^{\circ} \mathrm{C}\right)$, and two cold-sensitive, 'Frantoio' $\left(-12.3^{\circ} \mathrm{C}\right)$, 'Coratina' $\left(-11.8^{\circ} \mathrm{C}\right)$, cultivars. That study also revealed that the sensitivity of tissues was in the order roots $>$ leaves $>$ shoots $>$ vegetative buds. The sensitivity of roots is understandable because they do not experience low temperatures that characterize the aerial environment and therefore do not harden. The tolerance of vegetative buds contrasts with the sensitivity of floral buds and flowers.

Water stress improves the ability of olive to super cool and therefore to tolerate freezing, presumably by concentrating the aqueous phase of the cell solution. Certainly, Palliotti and Bongi (1996) showed that the increased tolerance they recorded in coldsensitive 'Frantoio' to treatment with mefluidide, a plant growth regulator, was associated with a decrease in leaf relative water content. Perhaps this relationship reveals a further adaptive advantage of the leaf water shortage that olive experiences in winter despite high soil moisture content and low evaporative demand. Pavel and Fereres (1998) working with 'Picual', showed that leaf water stress in winter had its origin in low water uptake 
caused by decreased hydraulic conductivity of the root system. The cause, either physiological change in roots or some pattern of root senescence, has not been investigated.

\section{Salinity}

Salinity, either naturally occurring or induced by irrigation, is a major concern in many semi-arid areas to which olive is climatically adapted. The major salt concerned is $\mathrm{NaCl}$, but $\mathrm{SO}_{4}{ }^{2-}, \mathrm{HCO}_{3}{ }^{-}$, and $\mathrm{CO}_{3}{ }^{2-}$ ions may also be present. The salinity of the saturated soil extract and of irrigation water can be measured most easily by electrical conductivity $\left(\mathrm{EC}, \mathrm{dS} \mathrm{m}{ }^{-1}\right.$ at $25^{\circ} \mathrm{C}$ ), or summarized chemically as total dissolved salts $\left(\mathrm{g} \mathrm{L}^{-1}\right)$, but is most accurately described with details of particular ionic composition. As bench marks, EC of sea water falls in the range 50 to $60 \mathrm{dS} \mathrm{m}^{-1}$ and $3 \mathrm{ML}$ of irrigation water with EC = $1 \mathrm{dS} \mathrm{m}^{-1}$ adds $2 \mathrm{t}$ salt.

Olive is considered moderately tolerant to salinity (Gucci and Tattini 1997) but, as in all higher plants, growth is negatively affected by salinity in three ways. First, there is an osmotic effect in the soil solution that restricts the availability of water thus causing a water stress. Second, there are toxic effects of particular ions (most commonly $\mathrm{Na}^{+}$and $\mathrm{Cl}^{-}$) when they accumulate within tissues. Third, there is the metabolic energy expended in exclusion of salt by roots and/or its sequestration within the plant. In these ways, salt has many effects on physiological processes, including water relations, photosynthesis, nutrition, biomass partitioning, and fruit quality.

The accumulation of salt modifies leaf anatomy with effects on water relations (Section IIIB) and photosynthesis (Section VA). Leaves become thicker and have greater water content. Bongi and Loreto (1989) recorded increases in palisade cell length and mesophyll thickness of 38 and 50\%, respectively for plants, 'Rajo', exposed to $250 \mathrm{mM}$ salt. Water relations are also affected and osmotic adjustment is enhanced. Exposure of 1-year-old plants of 'Frantoio' and 'Leccino' (Gucci et al. 1997) to $200 \mathrm{mM}$ salt for 35 days reduced pre-dawn $\psi_{1}, \psi_{\pi}$ at full turgor, and $\psi_{\pi}$ at the point of turgor loss. Inorganic ions $\left(\mathrm{Na}^{+}, \mathrm{K}^{+}\right)$made the major contribution to lower $\psi_{\pi}$, but with significant contributions from glucose and mannitol. The two cultivars differed in their ability to accumulate inorganic ions but not carbohydrates. Net solute accumulation was greater in 'Leccino' than in the salt-tolerant 'Frantoio'.

Olive owes its tolerance to salinity to ability to restrict transport to shoots, isolate $\mathrm{Na}$ in vacuoles, and maintain a high $\mathrm{K} / \mathrm{Na}$ ratio to support tissue metabolism (see also Section VA), but a major component of its salinity tolerance actually resides in its ability to avoid salinity by restricting salt uptake by the roots. There is good evidence of variation in salt tolerance among cultivars of olive and Table 5 is constructed from experiments in which plant growth, and sometimes yield, have been used to evaluate relative tolerance to salt. An important point that has emerged during this review is that salt tolerance does not necessarily imply ability of individual physiological processes to withstand internal salt. Thus, it was shown that the salt-tolerant 'Frantoio' ceases photosynthesis at lower levels of leaf salt than does the salt-sensitive 'Leccino'. In this case, 'Frantoio' was successful by excluding salt rather than by tolerating it. As has been emphasized previously, the detailed physiological investigations on responses to salinity conducted at the leaf or at lower levels of organization, have not been matched by studies 
leading to a complete assessment of the salinity tolerance of olive and of its responses to salinity under the relevant field conditions. Thus, we do not yet have information on yield reductions expected in olive plantations of the major cultivars from irrigating with saline waters.

\section{Waterlogging}

Although the roots of few plant species are able to tolerate anaerobic (lactate) respiration for considerable periods, most rely on a continuing supply of oxygen to sustain aerobic (Krebs Cycle) respiration to provide energy for metabolic processes associated with growth and nutrient uptake. Roots can acquire adequate oxygen directly from the air within drained soils or through specialized aerenchyma tissue that conducts air from shoots to roots in species, e.g. rice, that are adapted to waterlogged conditions. Olive, in common with most plants, is susceptible to waterlogging (Navarro and Parra 1998) and plantations are advisably located where inundation does not occur, or where raised tree lines or surface drains can shed water rapidly. Despite the well known sensitivity of olive plantations to waterlogging, there have, however, been no studies on the anatomy and physiology of the response of olive to waterlogging or in search of differential adaptations between cultivars.

\section{INTEGRATION OF RESPONSES}

Two techniques are currently available to evaluate the interactions between component physiological responses of crops. The first considers responses of growth and yield in terms of resource-use efficiencies for radiation, water, and nitrogen. These efficiencies are the quantities of biomass or yield per unit of radiation intercepted (RUE), water used (WUE), water transpired (TE), and nitrogen uptake (NUE). Biomass and yield can also be expressed in terms of glucose requirement to facilitate comparisons between organs of different chemical composition. The second is the construction of physiologically based simulation models of crop development, growth, partitioning, and yield in response to environment and management. There are many such models for herbaceous field crops (van Ittersum and Donatelli 2002) and some for perennial fruit crops also (e.g. DeJong and Goudriaan 1989; Grossman and DeJong 1994).

There are, as yet, few integrative studies for olive. Some work on leaf photosynthesis, referred to earlier, has been extended to evaluations of RUE (Mariscal et al. 2000b) and TE (Moriana et al. 2002), but nothing has been reported on NUE. In any event, that level of analysis is well removed from the functioning of entire trees, which should be an important focus for physiological research. There is now some work at the orchard level on the redistribution of rainfall intercepted by canopies (Gómez et al. 2001), interception of radiation (Villalobos et al. 1995; Mariscal et al. 2000a), transpiration and photosynthesis of trees (Diaz-Espejo et al. 2002), evapotranspiration (Bonachela et al. 1998; Villalobos 1999), and growth and partitioning of biomass (Villalobos 1999; Mariscal et al. 2000b). The complexities of working with tree crops must be acknowledged but so also must be the importance and utility of models as the only known means to integrate knowledge for practical application and as a guide for research effort.

For olive, system-thinking will be useful in identifying the major shortcomings in knowledge of root systems, the complexity of flowering response, the hydraulic architecture of trees, the photosynthesis of canopies, and the filling of fruit. Simulation 
modelling offers the only known opportunity to build frameworks of interacting processes to evaluate available information and to guide future research but this research technique has hardly been applied to the study of olive (Villalobos 1999). To make significant progress, physiological research needs now to turn to more comprehensive studies of whole-tree and orchard systems and develop simulation models at various levels. It would probably be a great advantage if research in various places concentrated on few cultivars, perhaps selected from those now being planted worldwide in new plantation methods. A modeling framework that can provide a means to evaluate the relevance of currently available information and identify what new information is urgently required, and in what form.

\section{RECOMMENDATIONS FOR FUTURE RESEARCH}

The following recommendations for future research are discussed under the headings of phenological development, and the balances of carbon, water, and nutrients that form the logic of simulation models.

\section{A. Phenological Development.}

The internal mechanisms by which fruit load effects flowering behavior in the following year have received much attention. While this helps explain what occurs in the field, there has been relatively less effort to quantitatively define the role of environment on flowering and other aspects of phenological development. The substantial work on response to cold and temperature alternation has not been extended to the development of predictive models of phenological development such as exist for many field crops. An understanding of how the environment establishes signals for development could help untangle the present confusion about internal controls and provide a more secure way to seek appropriate cultivar-location combinations for new production environments.

\section{B. Carbon Accumulation and Partitioning.}

Leaves are clearly the dominant organs of carbon acquisition and it is evident that studies of leaf photosynthesis dominate the physiological literature about olive. Despite the many studies of leaf gas exchange, studies on the $\mathrm{C}$ balance of entire trees that include photosynthesis, respiration, partitioning of biomass, and fruit filling are missing. The measurements on leaf photosynthesis, together with the start that has been made on the illumination patterns of orchard canopies, can provide inputs to studies (and models) of tree and orchard photosynthesis. Such studies are needed to understand the effect of canopy illumination on flower survival, fruit fall, and competition with shoot growth during fruit filling. There is little information on competition between leaf and shoot growth, nothing on the role of assimilate storage $(\mathrm{C}$ and $\mathrm{N})$ in stems and roots in tree growth or survival, or the energy cost of the growth and maintenance of root systems. Studies are needed of the quantitative contribution that the olive fruit, which remains green for many months and has an internal supply of $\mathrm{CO}_{2}$ from intense respiration, make to growth and oil formation and how this contribution can be maximized.

\section{Water Relations}

In common with studies on many trees, leaves have been the focus of evaluations of drought resistance in olive. Tree water balance, however, also has components of uptake and storage, and there is little information on olive at this level. There are a few, but 
contradictory, measurements of the extent of root systems but little on their seasonal dynamics and activity. Important questions relate to the uptake of water by root systems and the possibilities for internal redistribution. How does root growth and activity relate to the formation of new leaves, quantitatively and anatomically? How does the complex stomatal behavior influence the transpiration of canopies of different densities and arrangements? What is the quantitative relationship between leaf area and the sapwood that supports it? Are there preferential flow pathways within the tree? What are the relative contributions of sapwood, heartwood and canopy to diurnal and seasonal water status of the canopy?

\section{Nutrient Balance}

For centuries, olive has been produced in regions of marginal water supply where yield and hence extraction of nutrients have been small. Natural fertility, together with accessions of nutrients by rainfall and dust, have provided a continuing supply of nutrients for productivity. Recycling by leaf fall and heavy pruning also reduced nutrient export and thus deficits. However, adequate attention has not been paid to the question of whole crop nutrient balance that will become increasingly critical for the sustainability of new intensive production systems. This requires, as a first step, the construction of nutrient balance sheets for orchards taking into account extraction by yield, internal and external cycling in nutrient withdrawal through, litter fall, pruning, and cover crops, as well as losses by runoff erosion, and leaching. The contrast between the nutrient balances of high intensity production systems, on the one hand, and the current development of organic production systems for olive, place these issues in sharp perspective.

\section{CONCLUSION}

This review reveals that literature on the physiology of olive has expanded greatly in recent years providing much insight into the functioning and adaptation of the tree but that the distribution of effort has been uneven and has left important areas untouched. Areas of strong activity have been in photosynthesis and water relations of leaves, pollination, fruit set, tolerance to salinity and freezing, and some micronutrient issues. Areas that have received little attention include environmental control over flowering together with the assimilate, water and nutrient balances of entire trees, including fruit and root systems, as they affect productivity and adaptation.

One noticeable feature of the literature is that a wide range of cultivars has been studied and yet few differences have been established between them at the physiological level. This can be explained by the genetic proximity that characterizes olive cultivars in response to vegetative propagation and longevity of the tree. Conflicts in the literature on relative freezing tolerance of cultivars, and to a lesser extent on salinity tolerance, are noteworthy. An exception may be in the terminal processes that determine oil quality. Cultivars are major determinants of quality, although that too is under, as yet incompletely understood, environmental control. Another feature is the amount of work that has been performed under conditions far removed from the field. There is a concentration of work on plants in pots in controlled environments that continues the emphasis on leaf physiology at the expense of whole-tree responses in the field. There is 
a real danger that the literature contains too many 'exact answers to approximate problems'. It will be a major challenge to assemble the totality of physiological responses that determines the climatic adaptation, growth, and yield responses of what are often large (and old and substantially manipulated) trees. Progress will require investment of effort more evenly across responses in realistic field environments if an adequate understanding of the processes that determine productivity and adaptability is to emerge.

In contrast to wheat and barley, the other long-standing crops of importance that evolved with it in the Mediterranean region, physiological understanding of olive remains influenced by folklore. That difference cannot be explained only by its more complicated perennial growth habit alone. Perhaps part of the answer resides in globalization. Wheat and barley spread more quickly to other continents and cultures that have applied additional scientific skills to their study and development. Olive has remained a regional crop, but that too is changing. Perhaps we are now poised for more intense interest, scientific activity, and understanding of olive.

\section{LITERATURE CITED}


November 25 am

Abdel-Rahman, A.A. and H.M. El-Sharkawi. 1974. Response of olive and almond orchards to partial irrigation under dry-farming practices in semi-arid regions. II. Plant-soil water relations in olive during the growing season. Plant Soil 41: 13-31.

Acebedo, M.M., M.L. Cañete, and J. Cuevas. 2002. Processes affecting fruit distribution and its quality in the canopy of olive trees. Adv. Hort. Sci. 14: 169-175.

Alcalá, A.R. and D. Barranco. 1992. Prediction of flowering time in olive for the Córdoba olive collection. HortScience 27: 1205-1207.

Allen, R.G., L.S. Pereira, D. Raes, and M. Smith. 1998. Crop evapotranspiration. Guidelines for computing crop water requirements. Irrigation and drainage paper, No. 56. FAO, Rome.

Angelopoulos, K., B. Dichio, and C. Xiloyannis. 1996. Inhibition of photosynthesis in olive trees (Olea europaea L.) during water stress and rewatering. J. Exp. Bot. 47: 1093-1100.

Anon. 2000. Catálogo mundial de variedades de olivo. Consejo Oleícola International, Madrid.

Ayerza, R. and G.S. Sibbett. 2001. Thermal adaptability of olive (Olea europaea L.) to the Arid Chaco of Argentina. Agr. Ecosyst. Environ. 84: 277-285.

Barranco, D., C.C. de Toro, and H.F. Rapoport. 2002. Monopotassium phosphate $\left(\mathrm{PO}_{4} \mathrm{H}_{2} \mathrm{~K}\right)$ for olive fruit abscission. Acta Hort. 586: 263-266.

Barranco, D., G. Milona, and L. Rallo. 1994. Flowering dates of olive cultivars in Cordoba. Investigacion Agraria, Produccion y Proteccion Vegetales. 9: 213-220.

Barranco, D. and L. Rallo. 2000. Olive cultivars in Spain. Hort. Technol. 10: 107-110.

Bartolozzi, F. and G. Fontanazza. 1999. Assessment of frost tolerance in olive (Olea europaea L.). Scientia Hort. 81: 309-319.

Bidner-BarHava, N. and B. Ramati. 1967. Tolerance of three olive varieties to soil salinity in Israel. Expt. Agr. 3: 295-305.

Bollard, E.G. 1970. The physiology and nutrition of developing fruits. p. 387-425. In: A.C. Hulme (ed.). The biochemistry of fruits and their products. Academic Press, New York.

Bonachela, S., F. Orgaz, F.J. Villalobos, and E. Fereres. 1998. Measurement and simulation of evaporation from soil in olive orchards. Irrig. Sci. 18: 205-211.

Bongi, G. and S.P. Long. 1987. Light-dependant damage to photosynthesis in olive leaves during chilling and high temperature stress. Plant Cell Environ. 10: 241249.

Bongi, G. and F. Loreto. 1989. Gas-exchange properties of salt-stressed olive (Olea europaea L.) leaves. Plant Physiol. 90: 1408-1416.

Bongi, G. and A. Palliotti. 1994. Olive. p. 165-187. In: B. Schaffer and P.C. Anderson (eds.). Handbook of environmental physiology of fruit crops. CRC Press, Boca Raton, FL.

Bongi, G., M. Mencuccini, and G. Fontanazza. 1987a. Photosynthesis of olive leaves: effect of light flux density, leaf age, temperature, peltates, and $\mathrm{H}_{2} \mathrm{O}$ vapor pressure on gas exchange. J. Am. Soc. Hort. Sci. 112: 143-148. 
Bongi, G., G.F. Soldatini, and K.T. Hubick. 1987b. Mechanism of photosynthesis in olive tree (Olea europaea L.). Photosynthetica 21: 572-578.

Bosabalidis, A.M. and G. Kofidis. 2002. Comparative effects of drought stress on leaf anatomy of two olive cultivars. Plant Sci. 163: 375-379.

Bouranis, D.L., C.K. Kitsaki, S.N. Chorianopoulou, G. Aivalakis, and J.B. Drossopoulos. 1999. Nutritional dynamics of olive tree flowers. J. Plant Nutr. 22: 245-257.

Brodribb, T. 1996. Dynamics of changing intercellular $\mathrm{CO}_{2}$ concentration $\left(\mathrm{c}_{\mathrm{i}}\right)$ during drought and determination of minimum functional $\mathrm{c}_{\mathrm{i}}$. Plant Physiol. 111: 179-185.

Browse, J. and C. Somerville. 1991. Glycerolipid synthesis: biochemistry and regulation. Annu. Rev. Plant Physiol. Plant Mol. Biol. 42: 467-506.

Celano, G., B. Dichio, G. Montanaro, V. Nuzzo, A.M. Palese, and C. Xiloyannis. 1999. Distribution of dry matter and amount of mineral elements in irrigated and nonirrigated olive trees. Acta Hort. 474: 381-384.

Centritto, M., F. Loreto, and K. Chartzoulakis. 2003. The use of low $\left[\mathrm{CO}_{2}\right]$ to estimate diffusional and non-diffusional limitations of photsynthetic capacity of saltstressed olive. Plant Cell Environ. 26: 585-594.

Chartzoulakis, K., M.H. Loupassaki, M. Bertaki, and I. Androulakis. 2002. Effects of $\mathrm{NaCl}$ salinity on growth, ion content and $\mathrm{CO}_{2}$ assimilation rate of six olive cultivars. Scientia Hort. 1814: 235-247.

Chartzoulakis, K., A. Patakas, and A.M. Bosabalidis. 1999. Changes in water relations, photosynthesis and leaf anatomy induced by intermittent drought in two olive cultivars. Environ. Expt. Bot. 42: 113-120.

Citernesi, A.S., C. Vitagliano, and M. Giovannetti. 1998. Plant growth and root system morphology of Olea europaea L. rooted cuttings as influenced by arbuscular mycorrhizas. J. Hort. Sci. Biotech. 73: 647-654.

Cohen, M.E., E. Fereres, D.A. Goldhamer, M. Mata, and J. Girona. 2001. Assessment of peach tree responses to irrigation water deficits by continuous monitoring of trunk diameter changes. J. Hort. Sci. Biotech. 76: 55-60.

Connor, D.J. and A.J. Hall. 1997. Sunflower physiology. p. 113-182. In: A.A. Schneiter (ed.). Sunflower technology and production. Agron. Monogr. No. 35. ASACSSA-SSSA, Madison.

Connor, D.J. and T.R. Jones. 1985. Response of sunflower to strategies of irrigation. II. Morphological and physiological responses to water shortage. Field Crops Res. 12: 91-103.

Cowan, I.R. 1982. Regulation of water use in relation to carbon gain in higher plants. p. 589-613. In: O.L. Lange, P.S. Nobel, C.B. Osmond, and H. Ziegler (eds.). Physiological plant ecology II. Springer-Verlag, New York.

Cuevas, J., A.J. Diaz Hermoso, D. Galian, J.J. Hueso, V. Pinillos, M. Prieto, D. Sola, and V.S. Polito. 2001. Response to cross pollination and choice of pollinisers for the olive cultivars (Olea europaea L.) 'Manzanilla de Sevilla', 'Hojiblanca' and 'Picual'. Olivae. 85: 26-32.

Cuevas, J., L. Rallo, and H.F. Rapoport. 1994. Crop load effects on floral quality in olive. Scientia Hort. 59: 123-130.

de la Rosa, R., L. Rallo, and H.F. Rapoport. 2000. Olive floral bud growth and starch content during winter rest and spring budbreak. HortScience 35: 1223-1227. 
DeJong, T.M. and J. Goudriaan. 1989. Modeling peach fruit growth and carbohydrate requirements: reevaluation of the double-sigmoid growth pattern. J. Am. Soc. Hort. Sci. 114: 800-804.

Delgado, A., M. Benlloch, and R. Fernández-Escobar. 1994. Mobilization of boron in olive trees during flowering and fruit development. HortScience 29: 616-618.

Denney, J.O. and G.R. McEachern. 1983. An analysis of several climatic temperature variables dealing with olive reproduction. J. Am. Soc. Hort. Sci. 108: 578-581.

Diaz-Espejo, A., B. Hafidi, J.E. Fernández, and M.J. Palomo. 2002. Transpiration and photosynthesis of the olive tree: a model approach. Acta Hort. 586: 457-460.

Dichio, B., M. Romano, V. Nuzzo, and C. Xiloyannis. 2002. Soil water availability and relationship between canopy and roots in young olive trees (cv. Coratina). Acta Hort. 586: 255-258.

Dichio, B., C. Xiloyannis, K. Angelopoulos, V. Nuzzo, S.A. Bufo, and G. Celano. 2003. Drought-induced variations of water relations parameters in Oleo europaea $\mathrm{L}$. Plant Soil 257: 381-389.

Dimassi, K., I. Therios, A. Balatsos, I.T. Metzidakis, and D.G. Voyiatzis. 1999. The blooming period and self-fruitfulness in twelve Greek and three foreign olive cultivars. Acta Hort. 474: 275-278.

Dry, P.R. and B.R. Loveys. 1999. Grape shoot growth and stomatal conductance are reduced when part of the root system is dried. Vitis 38: 151-156.

Dry, P.R., B.R. Loveys, and H. During. 2000. Partial drying of the root-zone of grape. I. Transient changes in shoot growth and gas exchange. Vitis 39: 3-8.

Ehleringer, J. and R.W. Pearcy. 1993. Variation in quantum yield, for $\mathrm{CO}_{2}$ uptake among $\mathrm{C}_{3}$ and $\mathrm{C}_{4}$ plants. Plant Physiol. 73: 555-559.

Fabbri, A. and C. Benelli. 2000. Flower bud induction and differentiation in olive. J. Hort. Sci. Biotech. 75: 131-141.

Fahn, A. 1986. Structural and functional properties of trichomes of xeromorphic leaves. Ann. Bot. 57: 631-637.

FAOSTAT, 2003. FAO Statistical Databases. Agriculture Data Collection (Primary Crops). Vol. 2003, http://apps.fao.org/page/collections?subset=agriculture.

Faria, T., D. Silverio, E. Breia, R. Cabral, A. Abadia, J. Abadia, J.S. Pereira, and M.M. Chaves. 1998. Differences in the response of carbon assimilation to summer stress (water deficits, high light and temperature) in four Mediterranean tree species. Physiol. Plant. 102: 419-428.

Farinelli, D., M. Boco, and A. Tombesi. 2002. Intensity and growth period of the fruit components of olive varieties. Acta Hort. 586: 607-610.

Fereres, E. and D.A. Goldhamer. 1990. Deciduous fruit and nut trees. p. 987-1017. In: B.A. Stewart and D.R. Nielsen (eds.). Irrigation of agricultural crops. Amer. Soc. Agron. Monogr. No. 30. ASA, Madison, WI.

Fernández, J.E. and F. Moreno. 1999. Water use by the olive tree. J. Plant Prod. 2: 101162.

Fernández, J.E., F. Moreno, F. Cabrera, J.L. Arrue, and J. Martín-Aranda. 1991. Drip irrigation, soil characteristics and the root distribution and root activity of olive trees. Plant Soil 133: 239-251.

Fernández, J.E., F. Moreno, I.F. Giron, and O.M. Blazquez. 1997. Stomatal control of water use in olive tree leaves. Plant Soil 190: 179-192. 
Fernández, J.E., F. Moreno, J. Martin Aranda, and J. Lopez Galvez. 1993. Water status of olive trees under dry-farming and drip-irrigation. Acta Hort. 335: 157-164.

Fernández, J.E., F. Moreno, J. Martín-Aranda, and H.F. Rapoport. 1994. Anatomical response of olive roots to dry and irrigated soils. Adv. Hort. Sci. 8: 141-144.

Fernández, J.E., M.J. Palomo, A. Diaz Espejo, B.E. Clothier, S.R. Green, I.F. Giron, and F. Moreno. 2001. Heat-pulse measurements of sap flow in olives for automating irrigation: tests, root flow and diagnostics of water stress. Agr. Water Mgt. 51: 99123.

Fernández-Escobar, R. 1998. Fertilización. p. 229-249. In: D. Barranco, R. FernándezEscobar, and L. Rallo (eds.). El cultivo del olivo. Junta de Andalucía y MundiPrensa, Madrid.

Fernández-Escobar, R., D. Barranco, and M. Benlloch. 1993. Overcoming iron chlorosis in olive and peach trees using low-pressure trunk-injection method. HortScience 28: 192-194.

Fernández-Escobar, R., M. Benlloch, C. Navarro, and G.C. Martin. 1992. The time of floral induction in olive. J. Am. Soc. Hort. Sci. 117: 304-307.

Fernández-Escobar, R., G. Gómez-Valledor, and L. Rallo. 1983. Influence of pistil extract and temperature on in vitro pollen germination and pollen tube growth of olive cultivars. J. Hort. Sci. 58: 219-227.

Fernández-Escobar, R., R. Moreno, and M. García-Creus. 1999. Seasonal changes of mineral nutrients in olive leaves during the alternate-bearing cycle. Scientia Hort. 82: $25-45$.

Ferrara, E., G. Lorusso, F. Lamparelli, I.T. Metzidakis, and D.G. Voyiatzis. 1999. A study of floral biology and the technological features of seven olive cultivars of different origins. Acta Hort. 474: 279-283.

Fereres, E., D.A. Goldhamer, and L.R. Parsons. 2003. Irrigation water management of horticultural crops. HortScience 38: 1036-1042.

Flora, L.J. and M.A. Matore. 1993. Stachyose and mannitol transport in olive (Olea europaea L.). Planta 189: 484-490.

Garcia, J.M. and M. Mancha. 1992. Evolución de la biosíntesis de lípidos durante la maduración de las variedades de aceituna 'Picual' y 'Gordal'. Grasas y Aceites Sevilla. 43: 277-280.

Ghrisi, N., B. Boulouha, M. Benichou, and S. Hilali. 1999. Agro-physiological evaluation of the phenomenon of pollen compatibility in olive. Case of the Mediterranean collection at the Menara Station, Marrakech. Olivae 79: 51-59.

Giménez, C., E. Fereres, C. Ruz, F. Orgaz, and K.S. Chartzoulakis. 1997. Water relations and gas exchange of olive trees: diurnal and seasonal patterns of leaf water potential, photosynthesis and stomatal conductance. Acta Hort. 449: 411-415.

Giorgelli, F., A. Minnocci, A. Panicucci, C. Vitagliano, and G. Lorenzini. 1994. Effects of long-term $\mathrm{SO}_{2}$ pollution on olive-tree gas exchange and leaf morphology. Acta Hort. 356: 185-188.

Giorio, G. and R. d'Andria. 2002. Sap flow estimated by compensation heat-pulse velocity technique in olive trees under two irrigation regimes in Southern Italy. Acta Hort. 586: 401-404.

Giorio, P. and G. Giorio. 2003. Sap flow of several olive trees estimated with the heatpulse technique by continuous monitoring of a single gauge. Environ. Expt. Bot. 49: 9-20. 
Giorio, P., G. Sorrentino, and R. d' Andria. 1999. Stomatal behaviour, leaf water status and photosynthetic response in field-grown olive trees under water deficit. Environ. Expt. Bot. 42: 95-104.

Gómez, J.A., J.V. Giraldez, and E. Fereres. 2001. Rainfall interception by olive trees in relation to leaf area. Agr. Water Mgt. 49: 65-76.

Grammatikopoulos, G., G. Karabourniotis, A. Kyparissis, Y. Petropoulou, and Y. Manetas. 1994. Leaf hairs of olive (Olea europaea) prevent stomatal closure by ultraviolet-B radiation. Austral. J. Plant Physiol. 21: 293-301.

Griggs, W.H., H.T. Hartmann, M.V. Bradley, B.T. Iwakini, and J. Whisler. 1975. Olive pollination in California. California Agr. Expt. Sta. Bul. 869.

Grossman, Y.L. and T.M. DeJong. 1994. PEACH: a simulation model of reproductive and vegetative growth in peach trees. Tree Physiol. 14: 329-345.

Gucci, R. and C. Cantini. 2000. Pruning and training systems for modern olive growing. CSIRO Publishing, Collingwood, Victoria, Australia.

Gucci, R., E. Gravano, A. Moing, and J.P. Gaudillere. 1998a. Ripartizione dei carboidrati in giovani piante de olivo soggette a stress salino o deficit idrico. Atti Giornate Scientifiche - San Remo 1-3: 383-384.

Gucci, R., L. Lombardini, and M. Tattini. 1997. Analysis of leaf water relations in leaves of two olive (Olea europaea) cultivars differing in tolerance to salinity. Tree Physiol. 17: 13-21.

Gucci, R. and P.E.H. Minchin. 2002. Translocation of newly-assimilated carbon in the vegetative shoot of olive. Acta Hort. 586: 461-463.

Gucci, R., A. Moing, E. Gravano, and J.P. Gaudillere. 1998b. Partitioning of photosynthetic carbohydrates in leaves of salt-stressed olive plants. Austral. J. Plant Physiol. 25: 571-579.

Gucci, R. and M. Tattini. 1997. Salinity tolerance in olive. Hort. Rev. 21: 177-213.

Hacke, U.G. and J.S. Sperry. 2003. Limits to xylem refilling under negative pressure in Laurus nobilis and Acer negundo. Plant Cell Environ. 26: 303-311.

Hackett, W.P. and H.T. Hartmann. 1964. Inflorescence formation in olive as influenced by low temperature, photoperiod, and leaf area. Bot. Gaz. 125: 65-72.

Hackett, W.P. and H.T. Hartmann. 1967. The influence of temperature on floral intiation in olive. Physiol. Plant. 20: 430.436.

Hartmann, H.T. 1953. Effect of winter chilling on fruitfulness and vegetative growth in olive. Proc. Amer. Soc. Hort. Sci. 62: 184-190.

Hartmann, H.T. and I.C. Porlingis. 1958. Effects of different amounts of winter chilling on fruitfullness of several olive varieties. Bot. Gaz. 119: 102-104.

Hartmann, H.T., A. Tombesi, and J. Whisler. 1970. Promotion of ethylene evolution and fruit abcission in the olive by 2-cloroethane phosphonic acid and cycloheximide. J. Am. Soc. Hort. Sci. 95: 635-650.

Hartmann, H.T. and J.E. Whisler. 1975. Flower production in olive as influenced by various chilling temperature regimes. J. Am. Soc. Hort. Sci. 100: 670-674.

Hayman, D.S., J.M. Barea, and R. Azcon. 1976. Vesicular-arbuscular mycorrhiza in southern Spain: its distribution in crops growing in soil of different fertility. Phytopathol. Mediter. 15: 1-6.

Hermoso, M., M. Uceda, L. Frías, and G. Beltrán. 1998. Maduracíon. p. 145-161. In: D. Barranco, R. Fernández-Escobar, and L. Rallo (eds.). El cultivo del olivo. Junta de Andalucia y Mundi-Prensa, Madrid. 
Hsiao, T.C. 1973. Plant responses to water stress. Annu. Rev. Plant Physiol. 24: 519-570.

Jordão, P.V. and F. Lietão. 1990. The olive's mineral composition and some parameters of quality in fifty olive cultivars grown in Portugal. Acta Hort. 286: 461-464.

Karabourniotis, G., K. Papadopoulos, M. Papamarkou, and Y. Manetas. 1992. Ultraviolet-B radiation absorbing capacity of leaf hairs. Physiol. Plant. 86: 414418.

Kitsaki, C.K., J.B. Drossopoulos, G. Aivalakis, F. Anastasiadou, and C. Delis. 1999. In vitro studies of ABA and ethephon induced abscission in olive organs. J. Hort. Sci and Biotech. 74: 19-25.

Kramer, P.J. and J.S. Boyer. 1995. The water relations of plants and soils. Academic Press, San Diego.

Kreuger, W.H., Z. Heath, and B. Mulqueeney. 2002. Effect of spray solution concentration, active ingedient, additives and sequential treatments of napthalene acetic acid for chemical thinning of Manzanillo table olives (Olea europaea). Acta Hort. 586: 267-269.

Larcher, W. 1987. Regional distribution of plants and their adaptive responses to low temperatures - Mediterranean sclerophylls. p. 174-234. In: A. Sakai and W. Larcher (eds.). Frost survival of plants. Responses and adaptation to freezing stress. Springer Verlag, Berlin.

Larcher, W., J.A.P.V. De Moraes, and H. Bauer. 1981. Adaptive responses of leaf water potential, $\mathrm{CO}_{2}$-gas exchange and water use efficiency of Olea europaea during drying and rewatering. p. 77-84. In: N.S. Margaris and H.A. Mooney (eds.). Components of productivity of Mediterranean-climate regions. Basic and applied aspects. Dr. W. Junk, The Hague.

Lavee, S. 1986. Olive. p. 261-276. In: S.P. Monselise (ed.). CRC handbook of fruit set and development. CRC Press, Boca Raton, Florida.

Lavee, S. 1990. Aims, methods, and advances in breeding of new olive (Olea europaea L.) cultivars. Acta Hort. 286: 23-36.

Lavee, S. 1996. Biology and physiology of the olive. p. 59-110. In: IOOC (ed.). World Olive Encyclopaedia. Plaza \& Janés Editorial, Barcelona.

Lavee, S., L. Rallo, H.F. Rapoport, and A. Troncoso. 1999. The floral biology of the olive. II. The effect of inflorescence load and distribution per shoot on fruit set and load. Scientia Hort. 82: 181-192.

Legge, N.J. 1985. Anatomical aspects of water movement through stems of Mountain Ash (Eucalyptus regnans F. Muell). Austral. J. Bot. 33: 287-298.

Liakoura, V., S. Stanvrianakou, G. Liakopoulos, G. Karabourniotis, and Y. Manetas. 1999. Effects of UV-B radiation on Olea europaea: comparisons between a greenhouse and field experiment. Tree Physiol. 19: 905-908.

Lo Gullo, M.A., A. Nardini, S. Salleo, and M.T. Tyree. 1998. Changes in root hydraulic conductance $\left(\mathrm{K}_{\mathrm{R}}\right)$ of Olea oleaster seedlings following drought stress and irrigation. New Phytol. 140: 25-31.

Loomis, R.S. and D.J. Connor. 1991. Strategies and tactics for water-limited agriculture in low rainfall environments. p. 441-465. In: E. Acevedo, E. Fereres, C. Giménez, and J.P. Srivastra (eds.). Improvement and management of winter cereals under temperature, drought and salinity stresses. INIA, Madrid.

Loomis, R.S. and D.J. Connor. 1992. Crop ecology: productivity and management in agricultural systems. Cambridge Univ. Press, Cambridge. 
Loreto, F., M. Centritto, and K. Chartzoulakis. 2003. Photosynthetic limitations in olive cultivars with different sensitivities to salt stress. Plant Cell Environ. 26: 595-601.

Loreto, F. and T.D. Sharkey. 1990. Low humidity can cause uneven photosynthesis in olive (Olea europaea L.) leaves. Tree Physiol. 6: 409-415.

MacNaughton, K.G. and P.G. Jarvis. 1983. Predicting effects of vegetation on transpiration and evaporation. p. 1-47. In: T.T. Koslowski (ed.). Water deficits and plant growth. Academic Press, New York.

Mancuso, S. 1998. Seasonal dynamics of electrical impedance parameters in shoots and leaves to rooting ability of olive (Olea europaea) cuttings. Tree Physiol. 19: 95101.

Mancuso, S. 2000. Electrical resistance changes during exposure to low temperature measure chilling and freezing tolerance in olive tree (Olea europaea L.) plants. Plant Cell Environ. 23: 291-299.

Manrique, T., H.F. Rapoport, J. Castro, and M. Pastor. 1999. Mesocarp cell division and expansion in the growth of olive fruits. Acta Hort. 474: 301-304.

Mariscal, M.J., F. Orgaz, and F.J. Villalobos. 2000a. Modelling and measurement of radiation interception by olive canopies. Agr. For. Meteorol. 100: 183-197.

Mariscal, M.J., F. Orgaz, and F.J. Villalobos. 2000b. Radiation-use efficiency and dry matter partitioning of a young olive (Olea europaea) orchard. Tree Physiol. 20: 65-72.

Martin, G.C. 1990. Olive flower and fruit population dynamics. Acta Hort. 286: 141-153.

Martínez-Vilalta, J., E. Prat, and I. Oliveras. 2002. Xylem hydraulic properties of roots and stems on nine Mediterranean woody species. Oecologia 133: 19-29.

McDermitt, D.K. and R.S. Loomis. 1981. Elemental composition of biomass and its relation to energy content, growth efficiency and growth yield. Ann. Bot. 48: 275290.

Meinzer, F.C., M.J. Clearwater, and G. Goldstein. 2001. Water transport in trees: current perspectives, new insights and some controversies. Environ. Expt. Bot. 45: 239262.

Merino, J. 1987. The costs of growing and maintaining leaves of Mediterranean plants. p. 553-564. In: J.D. Tenhuned, F.M. Catarino, O.L. Lange, W.V. Oechel (eds.), Plant response to stress. Functional analysis in Mediterranean ecosystems. NATO ISI Series, Vol. G15, Springer Verlag, Berlin.

Milburn, J.A. and R.P.C. Johnson. 1966. The conduction of sap. II. Detection of vibrations produced by sap cavitation. Planta 69: 43-52.

Minnocci, A., A. Panicucci, L. Sebastiani, G. Lorenzini, and C. Vitagliano. 1999. Physiological and morphological responses of olive plants to ozone exposure during a growing season. Tree Physiol. 19: 391-397.

Miranovic, K. 1994. Investigations of elayographic properties of the olive cultivar Zutica (Olea europaea L.). Acta Hort. 356: 74-77.

Mitchell, P.D. and D.J. Chalmers. 1982. The effect of reduced water supply on peach tree growth and yield. J. Am. Soc. Hort. Sci. 107: 853-856.

Mitchell, P.D., B. van den Ende, P.H. Jerie, and D.J. Chalmers. 1989. Response of 'Bartlet' pear to withholding irrigation, regulated deficit irrigation, and tree spacing. J. Am. Soc. Hort. Sci. 114: 15-19.

Moreno, F., J.E. Fernandez, B.E. Clothier, and S.R. Green. 1996. Transpiration and root water uptake by olive trees. Plant Soil 184: 85-96. 
Moriana, A., F. Orgaz, M. Pastor, and E. Fereres. 2003. Yield responses of a mature olive orchard to water deficits. J. Am. Soc. Hort. Sci. 128: 425-431.

Moriana, A., F.J. Villalobos, and E. Fereres. 2002. Stomatal and photosynthetic responses of olive (Olea europaea L.) leaves to water deficits. Plant Cell Environ. 25: 395405.

Mulas, M., F. Virdis, M. Schirra, and Mura.M. 1999. Fruit quality of table-olive clones selected from 'Nera' variety. Acta Hort. 474: 605-608.

Natali, S., C. Bignami, C. Cammilli, and M. Muganu. 1999. Effect of water stress on leaf movement in olive cultivars. Acta Hort. 474: 445-448.

Natali, S., C. Xiloyannis, and P. Angelini. 1985. Water consumptive use of olive trees (Olea europaea) and effect of water stress on leaf water potential and diffusive resistance. Acta Hort. 171: 341-345.

Navarro, C., R. Fernández-Escobar, and M. Benlloch. 1990. Flower bud induction in Manzanillo olive. Acta Hort. 286: 195-198.

Navarro, C. and M.A. Parra. 1998. Plantacíon. p. 163-195. In: D. Barranco, R. Fernández-Escobar, and L. Rallo (eds.). El cultivo del olivo. Junta de Andalucía y Mundi-Prensa.

Nogués, S. and N.R. Baker. 2000. Effects of drought on photosynthesis in Mediterranean plants grown under enhanced UV-B radiation. J. Exp. Bot. 51: 1309-1317.

Orgaz, F. and E. Fereres. 1998. Riego. p. 259-280. In: D. Barranco, R. FernándezEscobar, and L. Rallo (eds.). El cultivo del olivo. MundiPrensa, Madrid.

Ortega Nieto, J.M. 1945. Poda del olivo; con aplicacíon especial a las zonas de Ubeda y 'El Condado' (Jaen). Editora El Olivo, S.S.L., Jaen.

Owen, R.W., A. Giacosa, W.E. Hull, R. Haubner, B. Spiegelhalder, and H. Bartsch. 2000. The antioxidant/anticancer potential of phenolic compounds isolated from olive oil. Eur. J. Cancer. 36: 1235-1347.

Palese, A.M., V. Nuzzo, B. Dichio, G. Celano, M. Romano, C. Xiloyannis, M.I. Ferreira, and H.G. Jones. 2000. The influence of soil water content on root density in young olive trees. Acta Hort. 537: 329-336.

Palliotti, A. and G. Bongi. 1996. Freezing injury in the olive leaf and effects of mefluidide treatment. J. Hort. Sci. 71: 57-63.

Pastor, M., J. Castro, V. Vega, and M.D. Humanes. 1998. Sistemas de manejo del suelo. p. 197-236. In: D. Barranco, R. Fernández-Escobar, and L. Rallo (eds.). El Cultivo del Olivo. Junta de Andalucía y Mundi-Prensa, Madrid.

Pastor, M., J. Hidalgo, V. Vega, J. Girona, L. Soria, F. Orgaz, E. Fernández, J. Fernández, and J. Rojo. 2001. Programación de riegos en olivar. Consejería de Agric. y Pesca, Junta de Andalucía, Sevilla.

Pastor Munoz Cobo, M. and J. Humanes Guillen. 1996. Poda del olivo. Moderna olivicultura. Editorial Agric. Española, S.A., Madrid.

Patumi, M., R. d' Andria, V. Marsilio, G. Fontanazza, G. Morelli, and B. Lanza. 2002. Olive and olive oil quality after intensive monocone olive growing (Olea europaea L., cv. Kalamata) in different irrigation regimes. Food Chem. 77: 27-34.

Pavel, E.W. and E. Fereres. 1998. Low soil temperatures induce water deficits in olive (Olea europaea) trees. Physiol. Plant. 104: 525-532.

Penning de Vries, F.W.T., A.H.M. Brunsting, and A.H. van Laar. 1974. Product requirements and efficiency of biosynthesis: a quantitative approach. J. Theor. Biol. 45: 339-377. 
Perica, S., P.H. Brown, J.H. Connell, and H. Hu. 2002. Olive response to foliar boron application. Acta Hort. 586: 381-383.

Peuke, A.D., W.D. Jesche, and W. Hartung. 1994. The uptake and flow of C, N and ions between roots and shoots in Ricinus communis L. III. Long-distance transport of abscisic acid depending on nitrogen nutrition and salt stress. J. Exp. Bot. 45: 741747.

Pinney, K. and V.S. Polito. 1990. Flower initiation in Manzanillo olive. Acta Hort. 286: 203-205.

Priestley, C.A. 1977. The annual turnover of resources in young olive trees. J. Hort. Sci. 52: $105-112$.

Proietti, P. 2000. Effect of fruiting on leaf gas exchange in olive (Olea europaea L.). Photosynthetica 38: 397-402.

Proietti, P. and A. Palliotti. 1997. Contribution of the adaxial and abaxial surfaces of olive leaves to photosynthesis. Photosynthetica 33: 63-69.

Proietti, P. and A. Tombesi. 1996. Translocation of assimilates and source-sink influences on productive characteristics of the olive tree. Adv. Hort. Sci. 10: 1114.

Proietti, P., F. Famiani, and A. Tombesi. 1999a. Gas exchange in olive fruit. Photosynthetica 36: 423-432.

Proietti, P., A. Palliotti, and G. Nottiani. 1999b. Availability of assimilates and development of olive fruit. Acta Hort. 474: 297-300.

Rallo, L. 1998. Frutificacíon y Produccíon. p. 112-144. In: D. Barranco, R. FernándezEscobar, and L. Rallo (eds.). El cultivo del olivo. Junta de Andalucía y MundiPrensa, Madrid.

Rallo, L. and R. Fernández-Escobar. 1985. Influence of cultivar and flower thinning within the inflorescence on competition among olive fruit. J. Am. Soc. Hort. Sci. 110: 303-308.

Rallo, L. and G.C. Martin. 1991. The role of chilling in releasing olive floral buds from dormancy. J. Am. Soc. Hort. Sci. 116: 1058-1062.

Rallo, L., G.C. Martin, and S. Lavee. 1981. Relationship between abnormal embryo sac development and fruitfulness in olive. J. Am. Soc. Hort. Sci. 106: 813-817.

Rallo, L. and M.P. Suarez. 1989. Seasonal distribution of dry matter within the olive fruit-bearing limb. Adv. Hort. Sci. 3: 55-59.

Rallo, L., P. Torreno, and J.A. Vargas. 1994. Dormany and alternate bearing in olive. Acta Hort. 356: 127-136.

Rallo, P. and H.F. Rapoport. 2001. Early growth and development of the olive fruit mesocarp. J. Hort. Sci. Biotech. 76: 408-412.

Rapoport, H., G. Costagli, and R. Gucci. 2004. The effect of water deficit during early fruit development on olive fruit morphogenesis. J. Amer. Soc. Hort. Sci. 129: (in press).

Rapoport, H.F. 1998. Botanica y morfología. p. 34-60. In: D. Barranco, R. Fernández Escobar, and L. Rallo (eds.). El cultivo del olivo. Junta de Andalucía y MundiPrensa, Madrid.

Rapoport, H.F. and L. Rallo. 1991a. Fruit set and enlargement in fertilized and unfertilized olive oviaries. HortScience 26: 896-898.

Rapoport, H.F. and L. Rallo. 1991b. Postanthesis flower and fruit abscission in 'Manzanillo' olive. HortScience 116: 720-723. 
Reuter, D.J., J.B. Robinson, and C. Dutkiewicz. 1997. Plant analysis: an interpretation manual. CSIRO Publishing, Melbourne.

Rieger, M. 1995. Offsetting effects of reduced root hydraulic conductivity and osmotic adjustment following drought. Tree Physiol. 15: 379-385.

Rojo, C. 1840. Arte de cultivar del olivo. El Olivo S.L.L., Ubeda.

Roselli, G., G. Benelli, and D. Morelli. 1989. Relationship between stomatal density and winter hardiness in olive (Olea europaea L.). J. Hort. Sci. 64: 199-203.

Salleo, S., M.A. Lo Gullo, D. De Paoli, and M. Zippo. 1996. Xylem recovery from cavitation-induced embolism in young plants of Laurus nobilis. A possible mechanism. New Phytologist. 132: 47-56.

Salleo, S., M.A. Lo Gullo, and F. Oliveri. 1985. Hydraulic parameters measured in 1year-old twigs of some mediterraean species with diffuse porous wood: changes in hydraulic conductivity and their possible functional significance. J. Exp. Bot. 36: 1-11.

Salleo, S., A. Nardini, F. Pitt, and M.A. lo Gullo. 2000. Xylem cavitation and hydraulic control of stomatal conductance in laurel (Laurus nobilis L.). Plant Cell Environ. 23: 71-79.

Sánchez, J. 1994. Lipid photosynthesis in olive fruit. Progr. Lipid Res. 33: 97-104.

Sanz Encinas, M. and L. Montanes Garcia. 1997. Visual diagnosis of iron chlorosis. ITEA Produccion Vegetal. 93: 7-22.

Sanz-Cortés, F., J. Martínez-Calvo, M.L. Badenes, H. Bleiholder, H. Hack, G. Llacer, and U. Meier. 2002. Phenological growth stages of olive trees (Olea europaea). Ann. Appl. Biol. 140: 151-157.

Schulze, E.-D., J. Eermák, R. Matyssek, M. Penka, R. Zimmermann, F. Vasicek, W. Gries, and J. Kueera. 1985. Canopy transpiration and water fluxes in the xylem of the trunk of Larix and Picea trees - a comparison of xylem flow, porometer and cuvette measurements. Oecologia 66: 475-483.

Schulze, E.-D. and A.E. Hall. 1982. Stomatal responses, water loss and $\mathrm{CO}_{2}$ assimilation rates of plants in contrasting environments. p. 182-230. In: O.L. Lange, P.S. Nobel, C.B. Osmond, and H. Ziegler (eds.). Physiological plant ecology II. Springer-Verlag, New York.

Sebastiani, L., A. Minnocci, F. Scebba, C. Vitagliano, A. Panicucci, and G. Lorenzini. 2002. Physiological and biochemical reactions of olive genotypes during siterelevant ozone exposure. Acta Hort. 586: 445-448.

Sibbett, G.S. and L. Ferguson. 2002. Nitrogen, boron, and potassium dynamic in ON vs OFF cropped Manzanillo olive trees in California, USA. Acta Hort. 586: 369-373.

Sperry, J.S. 1995. Limitations on stem water transport and their consequences. p. 105124. In: B.L. Gartner (ed.). Plant stems: physiological and functional morphology. Academic Press, San Diego.

Sperry, J.S. 2003. Evolution of water transport and xylem structure. Intl. J. Plant Sci. 164: S115-127.

Sperry, J.S., J.R. Donnelly, and M.T. Tyree. 1988. A method for measuring hydraulic conductivity and embolism in xylem. Plant Cell Environ. 11: 35-40.

Stutte, G.W. and G.C. Martin. 1986. Effect of killing the seed on return to bloom of olive. Scientia Hort. 29: 107-113.

Taiz, L. and E. Zeiger. 1991. Plant physiology. Benjamin/Cummings, Redwood City, CA. 
Tattini, M., L. Lombardini, and R. Gucci. 1997. The effect of $\mathrm{NaCl}$ stress and relief on gas exchange properties of two olive cultivars differing in tolerance to salinity. Plant Soil 197: 87-93.

Thompson, R.G., M.T. Tyree, M.A. Lo Gullo, and S. Salleo. 1983. The water relations of young olive trees in mediteranean winter. Measurements of evaporation from leaves and conduction in wood. Ann. Bot. 52: 399-406.

Tognetti, R., L. Sebastiani, A. Minnocci, C. Vitagliano, and A. Raschi. 2002. Foliar responses of olive trees (Olea europaea L.) under field exposure to elevated $\mathrm{CO}_{2}$ concentration. Acta Hort. 586: 449-452.

Tognetti, R., L. Sebastiani, C. Vitagliano, A. Raschi, and A. Minnocci. 2001. Responses of two olive tree (Olea europaea L.) cultivars to elevated $\mathrm{CO}_{2}$ concentration in the field. Photosynthetica 39: 403-410.

Tombesi, A. 1994. Olive fruit growth and metabolism. Acta Hort. 356: 225-232.

Tous, J. and L. Ferguson. 1997. Olive growing in California (USA). Olivae 67: 18-26.

Troncoso, A., J. Prieto, and J. Liñan. 1978. Aclareo quimico de frutos en el olivar Manzanilla de Sevilla. Annal. Edafol. Agrobio. 37: 882-893.

Tyree, M.T. and F.W. Ewers. 1991. The hydraulic architecture of trees and other woody plants. New Phytol. 119: 345-360.

Tyree, M.T., S. Patiño, J. Bennink, and J. Alexander. 1995. Dynamic measurements of root hydraulic conductance using a high pressure flowmeter in the laboratory and field. J. Exp. Bot. 46: 83-94.

Tyree, M.T. and J.S. Sperry. 1988. Do woody plants operate near the point of catastrophic xylem disfunction caused by dynamic water stress? Answers from a model. Plant Physiol. 88: 574-580.

Tyree, M.T. and J.S. Sperry. 1989. Characterization and propagation of acoustic-emission signals of woody plants - towards an improved acoustic-emission counter. Plant Cell Environ. 12: 371-382.

Uceda, M. and M. Hermoso. 1998. La calidad del aceite de oliva. p. 547-572. In: D. Barranco, R. Fernández-Escobar, and L. Rallo (eds.). El cultivo del olivo. Junta de Andalucía y Mundi-Prensa, Madrid.

van Ittersum, M.K. and M. Donatelli. 2002. Modelling cropping systems: science, software and applications. Eur. J. Agron. 18: 188-393.

Villalobos, F.J. 1999. Modelling of carbon and water balances of olive (Olea europaea L.). Revista de Ciencias Agrarias. 22: 131-143.

Villalobos, F.J., F. Orgaz, and L. Mateos. 1995. Non-destructive measurement of leaf area in olive (Olea europaea L.) trees using a gap inversion method. Agr. For. Meteorol. 73: 29-42.

Villalobos, F.J., F. Orgaz, L. Testi, and E. Fereres. 2000. Measurement and modeling of evapotranspiration of olive (Olea europaea L.) orchards. Eur. J. Agron. 13: 155163.

Visioli, F., C. Galli, G. Galli, and D. Caruso. 2002. Biological activities and metabolic fate of olive oil phenols. Eur. J. Lipid Sci. Technol. 104: 677-684.

Vitagliano, C., A. Minnocci, L. Sebastiani, A. Panicucci, G. Lorenzini, I.T. Metzidakis, and D.G. Voyiatzis. 1999. Physiological response of two olive genotypes to gaseous pollutants. Acta Hort. 474: 431-434.

Wullschleger, S.D., F.C. Meinzer, and R.A. Vertessy. 1998. A review of whole-plant water use studies in trees. Tree Physiol. 18: 499-512. 
Xiloyannis, C., G. Celano, A.M. Palese, B. Dichio, and V. Nuzzo. 2002. Mineral nutrient uptake from the soil in irrigated olive trees, cultivar Coratina, over six years after planting. Acta Hort. 586: 453-456.

Xiloyannis, C., B. Pezzarossa, J. Jorba, and P. Angelini. 1988. Effects of soil water content on gas exchange in olive trees. Adv. Hort. Sci. 2: 58-63.

Yamada, H. and G.C. Martin. 1994. Physiology of olive leaf abscission induced by phosphorus. J. Am. Soc. Hort. Sci. 119: 956-963.

Zhang, J. and W.J. Davis. 1990. Changes in the concentration of ABA in the xylem sap as a function of changing soil water status will account for changes in leaf conductance. Plant Cell Environ. 13: 277-285. 
November $14 \mathrm{pm}$

\section{List of Tables}

Table 1. Diagnostic levels for nutrient concentrations in olive leaves. Source: Reuter (1997); Fernández-Escobar (1998).

Table 2. Nutrient concentrations (dry weight basis) in component organs of olive trees.

Table 3. Fruit and oil characteristics of six olive cultivars. Source: Farinelli et al. (2002).

Table 4. Some established tolerances of olive cultivars to freezing temperatures. Source: Roselli et al. (1989); Bartolozzi and Fontanazza (1999); Mancuso (2000).

Table 5. Some established tolerances of olive cultivars to salinity. Source: BidnerBarhava and Ramati (1967); Gucci and Tattini (1997). 
Table 1. Diagnostic levels for nutrient concentrations in olive leaves. Source: Reuter (1997); Fernández-Escobar (1998).

\begin{tabular}{ccccc}
\hline Nutrient & Deficient & Marginal & Adequate & Toxic \\
\hline $\mathrm{N}(\%)$ & $<1.4$ & & $1.5-2.0$ & \\
$\mathrm{P}(\%)$ & 0.05 & & $0.1-0.3$ & \\
$\mathrm{~K}(\%)$ & $<0.4$ & $0.4-0.8$ & $>0.8$ & \\
$\mathrm{Ca}(\%)$ & 0.3 & & $>1.0$ & \\
$\mathrm{Mg}(\%)$ & 0.08 & & $>0.1$ & \\
$\mathrm{Na}(\%)$ & & & $>0.2$ \\
$\mathrm{Cl}(\%)$ & & & $>4$ & \\
$\mathrm{Cu}(\mathrm{ppm})$ & & & $10-30$ & \\
$\mathrm{Zn}(\mathrm{ppm})$ & & & $>20$ & \\
$\mathrm{Mn}(\mathrm{ppm})$ & & & & \\
$\mathrm{Fe}(\mathrm{ppm})$ & & & $19-150$ & $>185$ \\
$\mathrm{~B}(\mathrm{ppm})$ & $<14$ & $14-18$ & & \\
\hline
\end{tabular}

Table 2. Nutrient concentrations (dry weight basis) in component organs of olive trees.

\begin{tabular}{|c|c|c|c|c|c|}
\hline \multirow[t]{2}{*}{ Nutrient } & \multicolumn{2}{|c|}{ Leaf $^{1}$} & \multirow{2}{*}{$\begin{array}{l}\text { Inflores- } \\
\text { cence }^{2}\end{array}$} & \multicolumn{2}{|c|}{ Fruit } \\
\hline & currrent & senescent & & Pulp $^{3}$ & Entire $^{4}$ \\
\hline N (\%) & 1.53 & 0.95 & 0.21 & & 0.72 \\
\hline P (\%) & 0.15 & 0.11 & 0.10 & 0.125 & 0.11 \\
\hline K (\%) & 0.60 & 0.40 & 0.60 & 1.930 & 1.09 \\
\hline Ca (\%) & 3.0 & 4.5 & 0.35 & 0.118 & 0.10 \\
\hline Mg (\%) & 0.12 & 0.10 & 0.03 & 0.046 & 0.03 \\
\hline $\mathrm{Na}(\%)$ & & & & 0.082 & \\
\hline Cl (\%) & & & & & \\
\hline $\mathrm{Fe}(\mathrm{ppm})$ & 35 & 22 & 125 & 24.5 & 30.9 \\
\hline Mn (ppm) & 40 & 32 & 16 & 4.3 & 4.1 \\
\hline $\mathrm{Cu}(\mathrm{ppm})$ & 60 & 50 & 12 & 9.1 & 9.3 \\
\hline $\mathrm{Zn}(\mathrm{ppm})$ & 17 & 15 & 12 & 27.0 & 7.6 \\
\hline B (ppm) & 32 & 30 & & & 7.9 \\
\hline
\end{tabular}

1. Fernández-Escobar et al. (1999). Leaves ('Picual', 12-year orchard) are means of age classes, dead leaves are oldest $(2+$ year) on tree. Note that mean leaf wt of $85 \mathrm{mg}$ was maintained in oldest leaves.

${ }^{2}$. Bouranis et al. (1999), 'Konservolia', 25 year, “on”, at full bloom. Inflorescences of 4 branches from mid-shoot positions reached maximum dry weight of c. $85 \mathrm{mg}$.

3. Mulas et al. (1999), means of 9 clones of 'Nera' (table olive)

4. Jordão and Lietão (1990). Means of 50 cultivars. 
Table 3. Fruit and oil characteristics of six olive cultivars. Source: Farinelli et al. (2002).

\begin{tabular}{lcccccc}
\hline \multicolumn{1}{c}{ Fruit characteristics } & Carolea & $\begin{array}{c}\text { Dulce } \\
\text { Agogia }\end{array}$ & Frantoio & Leccino & Maurino & Moraiolo \\
\hline Fruit dry mass (g) & 2.0 & 0.8 & 1.1 & 1.3 & 0.9 & 1.0 \\
Fruit volume (cm ${ }^{3}$ ) & 4.8 & 1.9 & 2.2 & 3.0 & 1.9 & 1.9 \\
Pulp/stone ratio (DW) & 2.7 & 1.6 & 1.5 & 1.3 & 1.6 & 1.9 \\
Final oil content pulp (\%DW) & 77.3 & 75.9 & 77.0 & 84.6 & 79.7 & 78.1 \\
Final oil content fruit (\%DW) & 56.1 & 44.7 & 45.8 & 47.6 & 49.2 & 51.1 \\
$\quad$ & & & & & & \\
$\quad$ Oil characteristics & 12.5 & 11.6 & 12.2 & 12.9 & 14.9 & 12.2 \\
Palmitic (\% of oil) & 2.0 & 1.8 & 1.8 & 1.7 & 1.3 & 1.6 \\
Stearic (\% of oil) & 75.5 & 77.3 & 77.1 & 76.4 & 73.4 & 75.0 \\
Oleic (\% of oil) & 5.7 & 6.0 & 6.4 & 5.2 & 7.0 & 7.3 \\
Linoleic (\% of oil) & 647 & 438 & 874 & 756 & 295 & 501 \\
Polyphenol (ppm of oil mass) & & & & & & \\
\hline
\end{tabular}

Table 4. Some established tolerances of olive cultivars to freezing temperatures. Source: Roselli et al. (1989); Bartolozzi and Fontanazza (1999); Mancuso (2000).

\begin{tabular}{cl}
\hline Tolerance & \multicolumn{1}{c}{ Cultivars } \\
\hline High & Ascolana Tenera, Bouteillan, Nostrale di Rigale, Leccino, Leccino Uzzano, \\
& Borciona, Madonna dell’Impruneta, Vocio, Morchiaio. \\
Low & Frantoio, Coratina, Moraiolo
\end{tabular}

Table 5. Some established tolerances of olive cultivars to salinity. Source: Gucci and Tattini (1997).

\begin{tabular}{cl}
\hline Tolerance & \multicolumn{1}{c}{ Cultivars } \\
\hline High & Megaritiki, Frantoio, Arbequina, Picual, Lechin de Sevilla, Chemlali \\
Low & Chondrolia, Chalkidikis, Leccino, Pajarero \\
\hline
\end{tabular}


November 21 am

\section{List of Figures}

Fig. 1. Pattern of dry matter accumulation in olive fruit from flowering to maturity under irrigated conditions (Tombesi 1994).

Fig. 2. The conductor- capacitor model for tree water relationships. The component organs of canopy, stems, and roots are connected by the xylem. Transpiration from canopy $(\mathrm{T})$ reduces canopy water potential $\left(\psi_{\mathrm{c}}\right)$ that draws water from stems and roots, and ultimately from soil. Water flows between components down gradients of water potential $(\Delta \psi)$ in proportion to pathway conductivities. Each organ has a capacitance $(\mathrm{Q})$ that releases water $(\mathrm{W})$ according to $\mathrm{Q}=\partial \mathrm{W} / \partial \psi$ and recovers it when $\mathrm{T}$ falls below root uptake.

Fig. 3. Relationships between midday leaf conductance $\left(\mathrm{g}_{1}, \mathrm{mmol} \mathrm{m}^{-2} \mathrm{~s}^{-1}\right)$ and vapour pressure deficit (VPD, $\mathrm{kPa}$ ) for olive trees at four levels of leaf water potential $\left(\Psi_{1}\right)$ (Moriana et al. 2002).

Fig. 4. Relationships between net photosynthetic rate (A) and leaf conductance $\left(\mathrm{g}_{1}, \mathrm{mmol}\right.$ $\mathrm{m}^{-2} \mathrm{~s}^{-1}$ ) for control and water-stressed olive trees (Angelopoulos et al. 1996).

Fig. 5. Influence of position in canopy on number of inflorescences, number of fruit, and fruit weight per shoot in 'Picual' and 'Arbequina' (Acebedo et al. 2002). The locations are on the periphery of the canopy at top (T), on east (E), west (W), south (S), and north (N) sides at $1.5 \mathrm{~m}$ height, and low (L) at $0.4 \mathrm{~m}$ on south side. The location within the canopy (I) is adjacent to L.

Fig. 6. Oil accumulation in the fruit (g) and specific accumulation rate ( $\left.\mathrm{mg} \mathrm{oil} \mathrm{g}^{-1} \mathrm{~d}^{-1}\right)$ according to fruit dry weight for six olive cultivars (Farinelli et al. 2002).

Fig. 7. Evolution of leaf water potential $\left(\psi_{1}\right)$ and leaf conductance $\left(g_{1}\right)$ in rain fed olive trees after $60 \mathrm{~mm}$ rainfall in November, 1995 following a prolonged drought at Córdoba, Spain. The open squares record the corresponding values of $\psi_{1}$ and $g_{1}$ for control trees that were irrigated and the crosses, $\mathrm{g}_{1}$ of rain fed trees that carried a heavy fruit load (E. Fereres, C. Ruz, and A. Soriano, unpublished). 


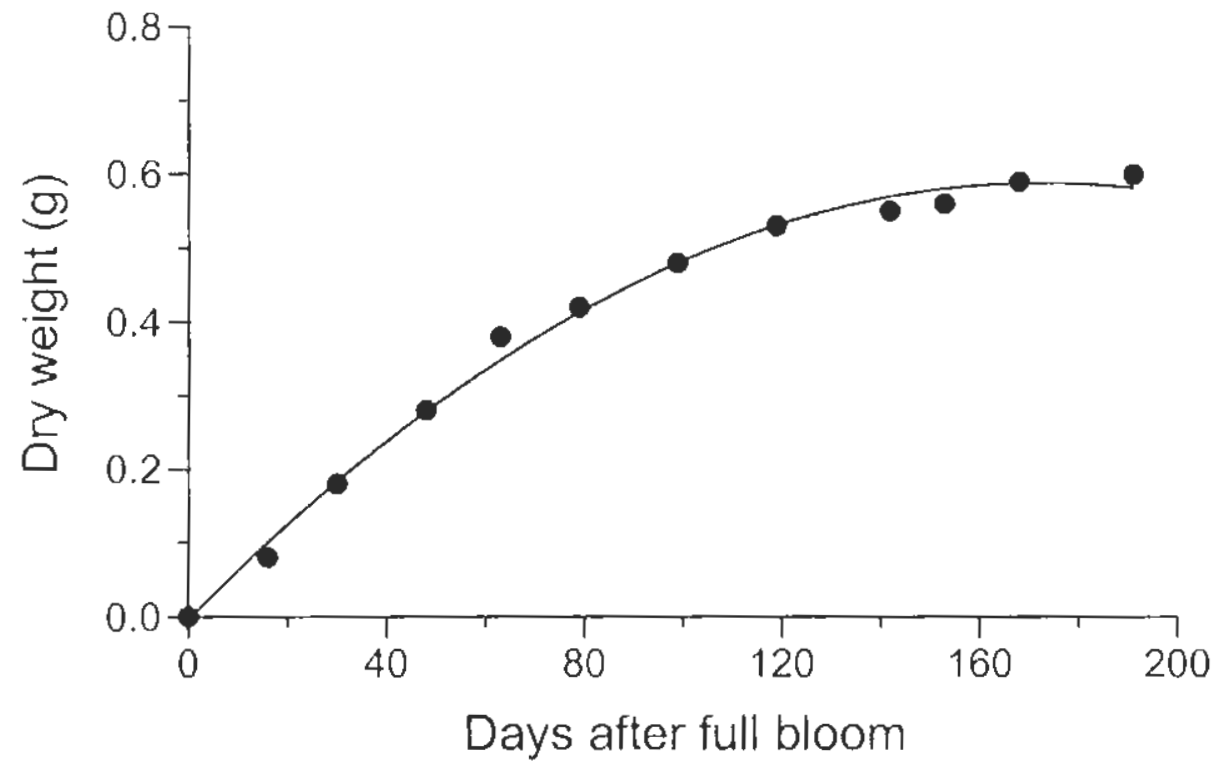

Figure 1 


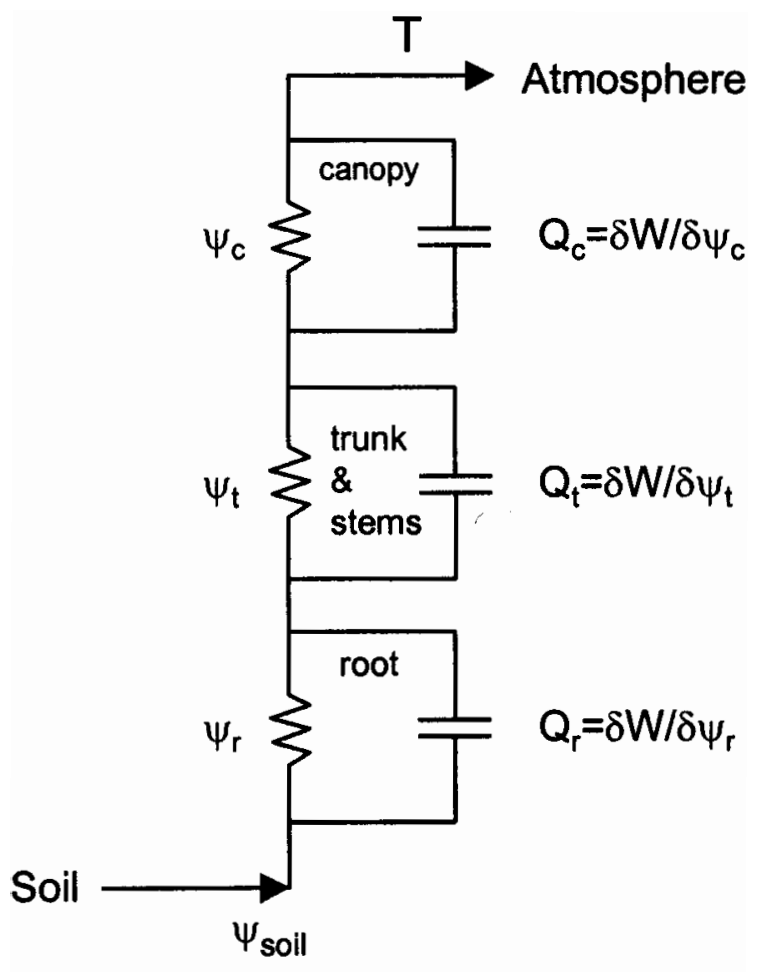

Figurure 2 


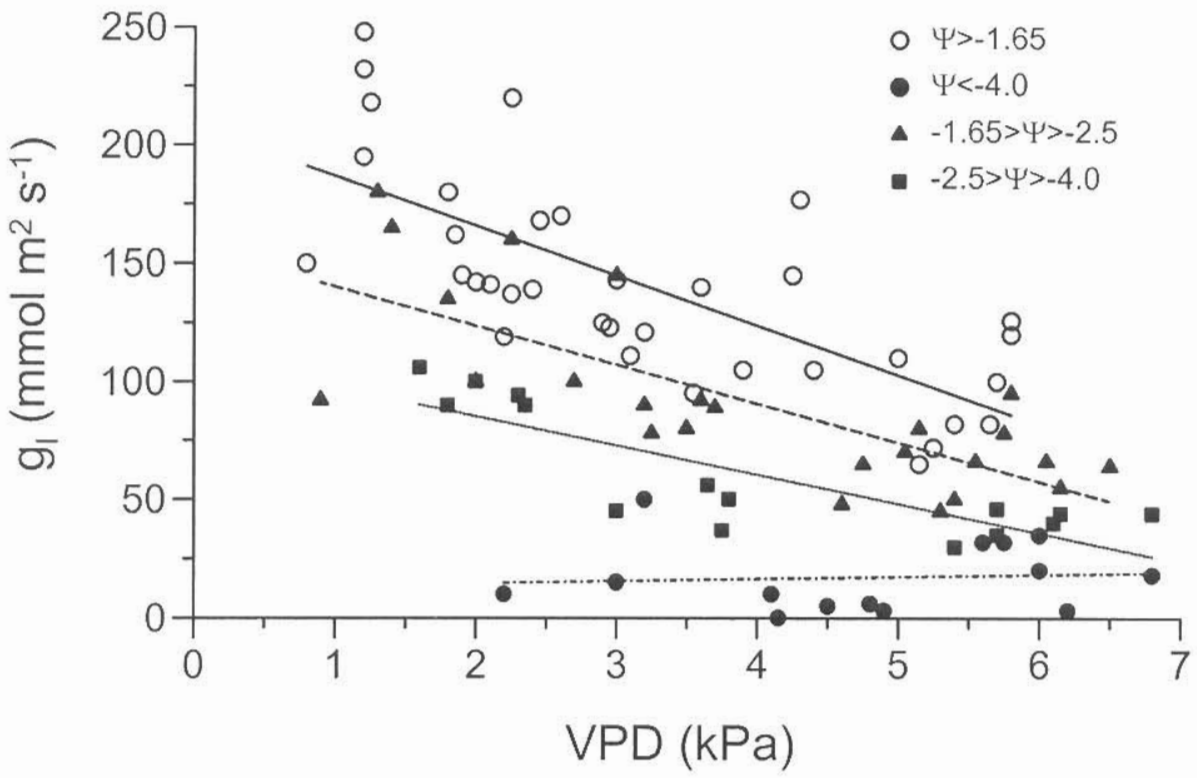

Figure 3 


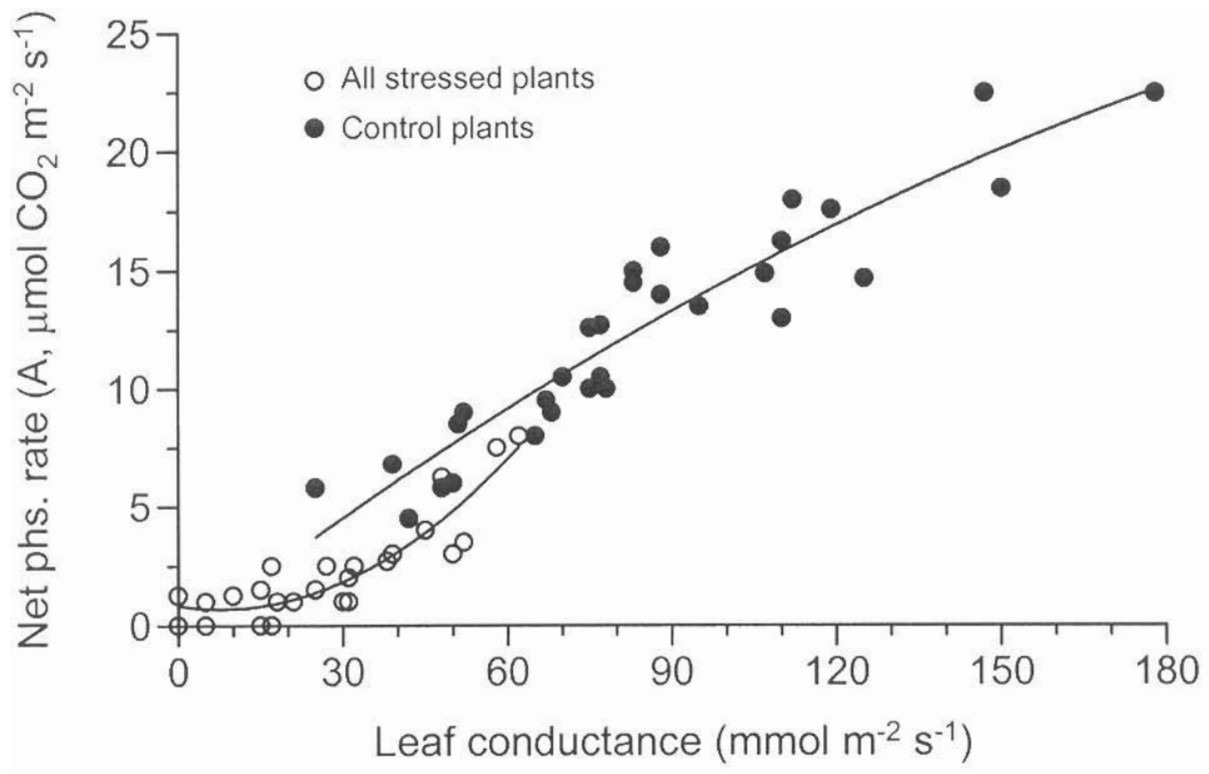

Figure 4 


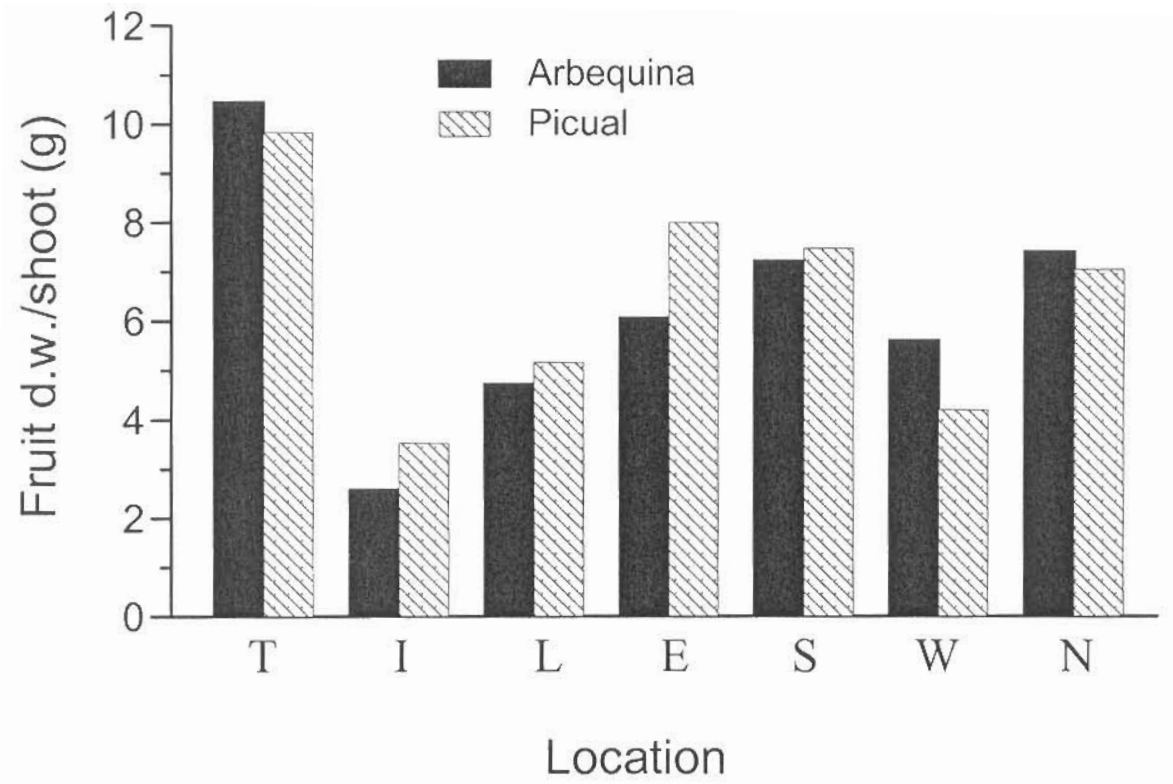

Figure 5 

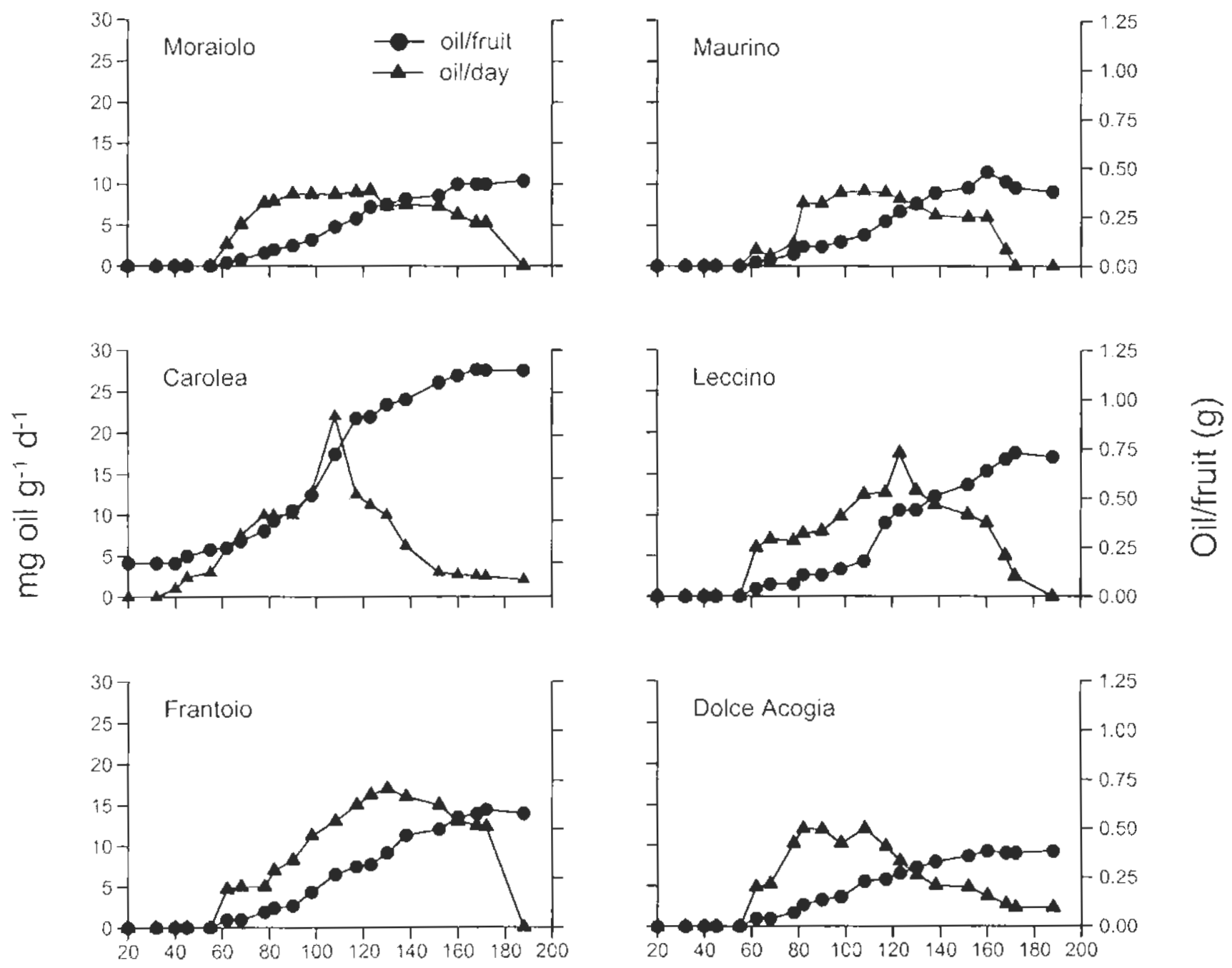

Days from full bloom

Figure 6 


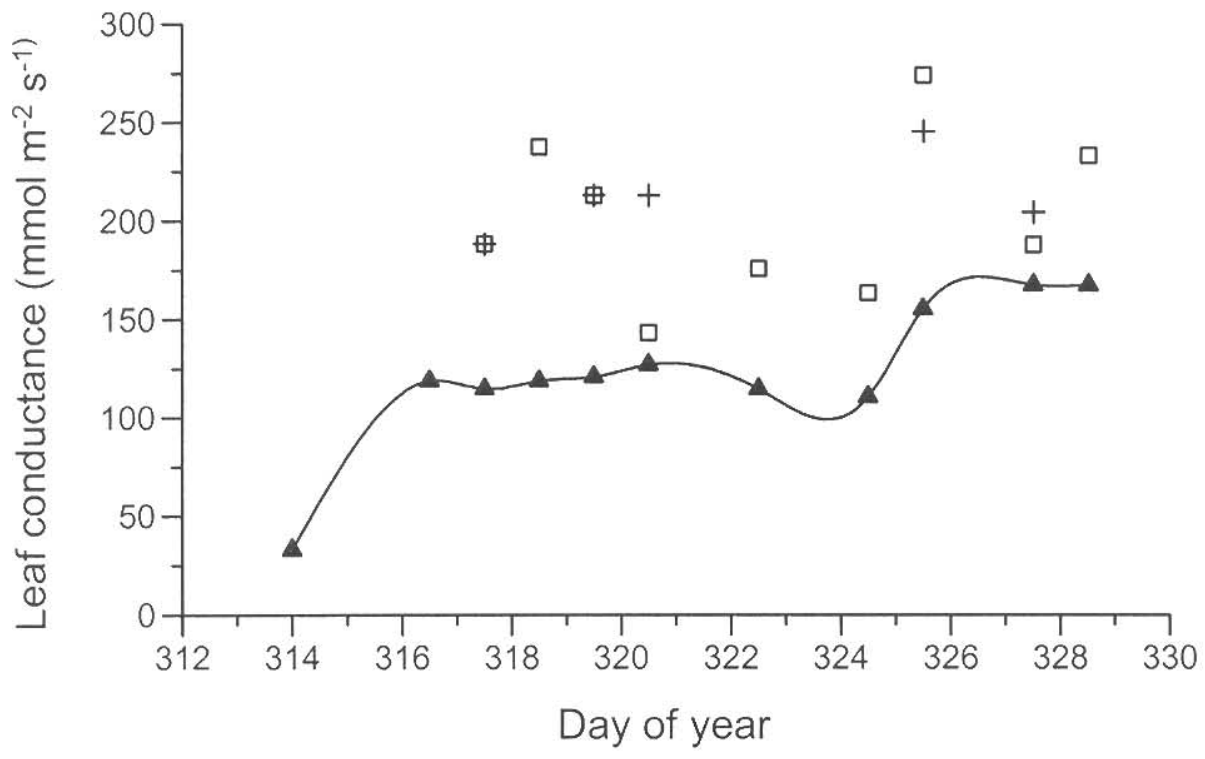

Figure 7 